\title{
MOVIMENTO DA ATRAZINA, DO CLORETO E DO \\ POTÁSSIO NUMA TERRA ROXA ESTRUTURADA \\ EUTRÓFICA
}

\author{
MANOEL DORNELAS DE SOUZA \\ Engenheiro Agrônomo
}

Orientador: Prof. Dr. KLAUS REICHARDT

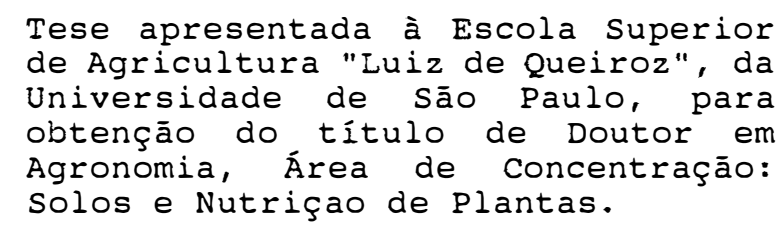

$P I R A C I C A B A$

Estado de São Paulo - Brasil

Novembro - 1993 
Ficha catalourefica preparada bela secto de hivros de

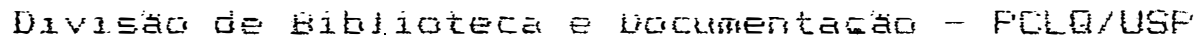

Sulza. Marioel Dornelas de

S73im Movimerto da atrazina, do cloreto e do fotassio numa terra roxa estruturada eutrofica. Firacicaba. 1998.

740.

TESE - ESALE

Eituicuratia.

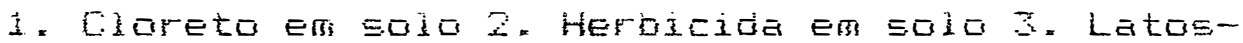

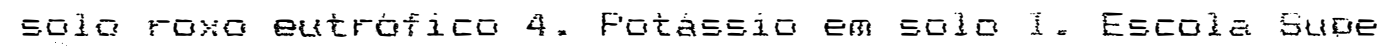
rior de Agricultura luz de dueiros. Firacicaba

CDD 651.44 


\section{MOVIMENTO DA ATRAZINA, DO CLORETO E DO POTÁSSIO NUMA TERRA ROXA ESTRUTURADA EUTRÓFICA}

MANOEL DORNELAS DE SOUZA

Aprovada em: 15/12/1993

Comissão julgadora:

Prof. Dr. KLAUS REICHARDT-ESALQ/USP

Dr. OSNY OLIVEIRA SANTOS BACCHI-CENA/USP

Prof. Dr. JORGE DE CASTRO KIEHL-ESALQ/USP

Dr. SÍLVIO CRESTANA-CNPDIA/EMBRAPA

Prof. Dr. EDUARDO BERNARDI LUCHESE-UEM/PARANÁ

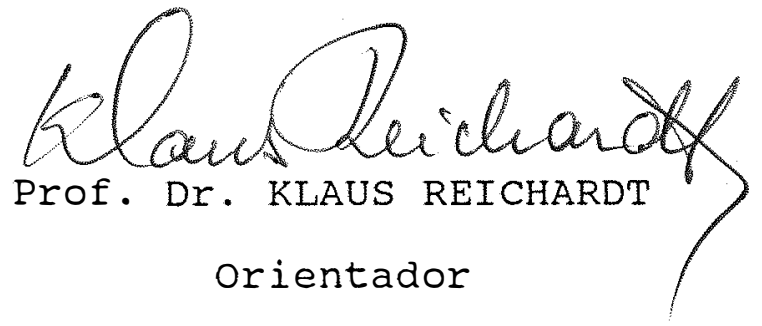


ii.

A meu filho Eric,

DEDICO. 
AGRADECIMENTOS

Ao Prof. Dr. KLAUS REICHARDT pelos conhecimentos transmitidos, pelo incentivo e pela orientação dada.

Aos colegas Luiz Carlos Hermes, Rosangela B. Abakerli, Liliam Akie Yoshikowa, José Ademir e João Eduardo Piloto pela ajuda nas análises.

À FAPESP pelo apoio financeiro, via projeto temático "Transporte, Previsão do Destino e Balanço de Pesticida no Solo". Processo número 90/3773-7.

A EMBRAPA pela bolsa de estudos concedida.

Ao Prof. Dr. Osny O. S. Bacchi pelo apoio e ajuda na instalação do experimento.

Ao Prof. Dr. Takashi Muraoka pela cooperação na análise química do solo.

Aos pesquisadores Dr. Gilberto Ribeiro Furlan e Dr. Valdemar Luis Tornisielo, do CENA, pela ajuda na análise de adsorção de atrazina.

E a todos aqueles que direta ou indiretamente contribuíram para a realização deste trabalho. 
Página

LISTA DE FIGURAS ....................... vi

LISTA DE TABELAS ....................... ix

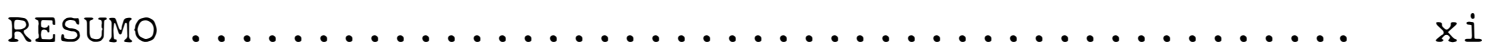

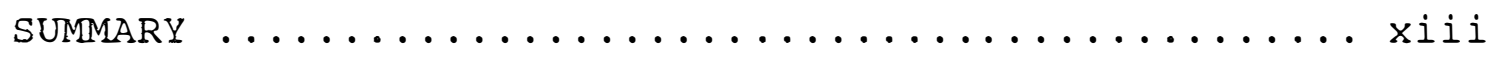

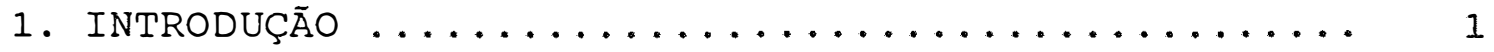

2. REVISÃO DE LITERATURA .................... 4

2.1. Atrazina no solo .................. 4

2.2. Potássio e cloreto no solo .............. 12

3. MATERIAL E MÉtOdOS ......................... 19

3.1. Área experimental .................... 19

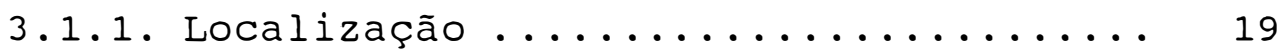

3.1.2. Clima regional ................ 19

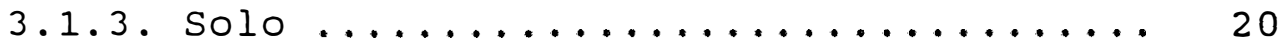

3.2. Descrição do experimento .............. 20

3.3. Determinaçōes e atividades ............. 24

3.3.1. Determinaçōes e atividades de campo ... 25

3.3.1.1. Condutividade hidráulica do solo saturado............ 25

3.3.1.2. Condutividade hidráulica do so10 não saturado ............. 26

3.3.1.3. Aplicação da atrazina ...... 28

3.3.1.4. Aplicação do cloreto de potássio $\ldots \ldots \ldots \ldots \ldots \ldots \ldots \ldots \ldots$

3.3 .1 .5 . Coletas de solução do solo ... 31 
3.3.1.6. Leitura de tensiômetros ..... 33

3.3 .1 .7 . Sonda de nêutrons ......... 33

3.3.1.8. Coleta de amostras para análises granulométricas e químicas 34

3.3.2. Determinações de laboratório ......... 34

3.3 .2 .1$. Atrazina ................ 34

3.3 .2 .2 . Cloreto e potássio ......... 37

3.3.2.3. Análises químicas e granulométricas ................... 37

3.3.2.4. Adsorção e dessorção de atrazina $\ldots \ldots \ldots \ldots \ldots \ldots \ldots \ldots \ldots$

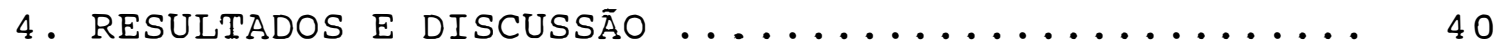

4.1. Condutividade hidráulica do solo saturado.. 40

4.2. Condutividade hidráulica do solo não saturado 44

4.3 . Lixiviação da atrazina .............. 51

4.4. Adsorção e dessorção de atrazina ......... 63

4.5. Lixiviação do cloreto e do potássio ....... 65

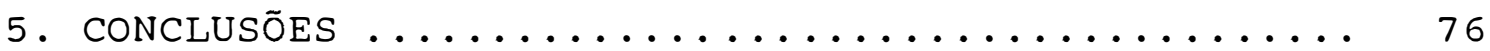

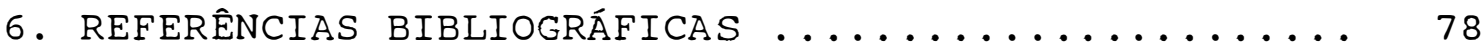

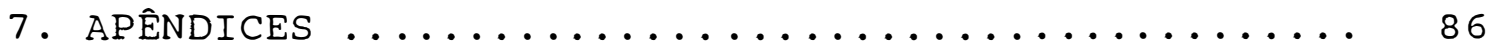


1. Esquema de uma das parcelas experimentais, indicando a colocação de tubos, tensiômetros e extra-

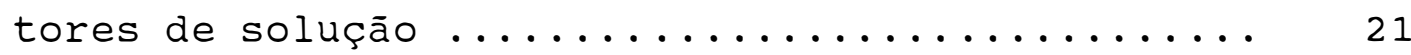

2. Disposição das parcelas no campo mostrando detalhes da colocação dos anéis para determinação da condutividade hidráulica saturada ........... 22

3. Detalhe da cobertura de uma das parcelas ....... 27

4. Evaporação acumulada, precipitação acumulada e irrigação acumulada no período de coleta de atrazina 30

5. Evaporação e irrigação acumuladas no período de coleta de solução do solo para determinação de

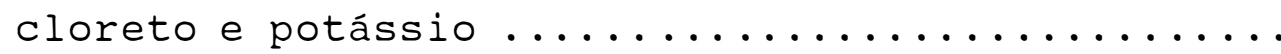

6. Variação da umidade durante determinação da condutividade hidráulica pelo método de Libardi et alii. (A) parcela 1 e (B) parcela $2 \ldots . . . \ldots \ldots$

7. Potencial total de água no solo na parcela 1 medido nos dias de coleta. (A) média da linha 1; (B) média da linha 2 e (C) média da linha $3 \ldots \ldots \ldots$

8. Perfis de umidade média nos dias de coleta de atrazina na parcela 1. (A) média da linha 1; (B) média da linha 2 e (C) média da linha $3 \ldots \ldots \ldots$

9. Concentração de atrazina por linha (A, B e C) e concentração média da parcela 1 (D). (A) média dos extratores da linha 1; (B) média dos extratores da 
vii.

Iinha 2 e (C) média dos extratores da linha $3 \ldots 55$

10. Potencial total de água no solo na parcela 2 medido nos dias de coleta. (A) média da linha 1 ;

(B) média da linha 2 e (C) média da linha $3 \ldots .$.

11. Perfis de umidade nos dias de coleta da atrazina na parcela 2. (A) média da linha 1; (B) média da Iinha 2 e (C) média da linha $3 \ldots \ldots \ldots \ldots$

12. Concentração de atrazina por linha ( $A, B$ e C) e concentração média da parcela 2 (D) . (A) média da linha 1; (B) média da linha 2 e (C) média da li-

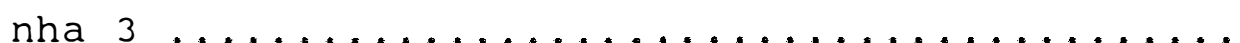

13. Potencial total de água no solo na parcela 1 no período de coleta de cloreto e potássio. (A) média da linha 1; (B) média da linha 2 e (C) média

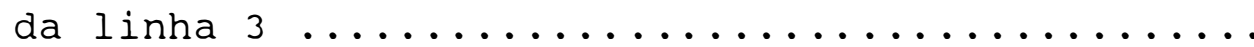

14. Concentração de potássio na solução do solo por linha ( $A, B$ e C) e média da parcela 1 (D). (A) média dos extratores da linha 1; (B) média dos extratores da linha 2 e (C) média dos extratores da linha 3

15. Concentração de cloreto na solução do solo por linha (A, B e C) e média da parcela 1 (D). (A) média dos extratores da linha 1; (B) média dos extratores da linha 2 e (C) média dos extratores

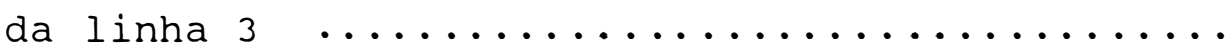


16. Potencial total de água no solo na parcela 2 no período de coleta de cloreto e potássio. (A) média da linha 1; (B) média da linha 2, e (C) média

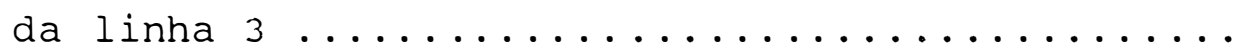

17. Concentração de potássio na solução do solo na parcela 2. (A) média dos extratores da linha 1; (B) média dos extratores da linha 2; (C) média dos extratores da linha 3 e (D) média da parce-

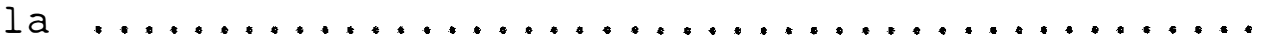

18. Concentração de cloreto na solução do solo na parcela 2. (A) média dos extratores da linha 1; (B) média dos extratores da linha 2; (C) média dos extratores da linha 3 e (D) média da parce-

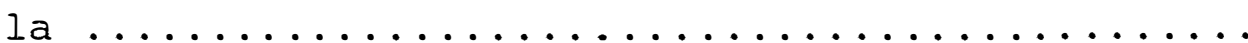


LISTA DE TABELAS

Página

1. Análise química do solo nas diferentes profundidades da parcela 1 e da parcela $2 \ldots \ldots \ldots \ldots \ldots \ldots$

2. Análise granulométrica e classes texturais nas diferentes profundidades da parcela 1 e da par-

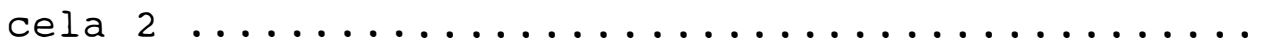

3. Valores de condutividade hidráulica do solo saturado obtidos em quatro épocas: época 1 (09/09/92); época $2(18 / 09 / 92)$; época $3(11 / 12 / 92)$ e época 4 (02/02/93), nas parcelas 1 e $2 \ldots \ldots \ldots \ldots \ldots$

4. Valores de umidade de saturação $\left(\theta_{0}\right)$ na parcela 1

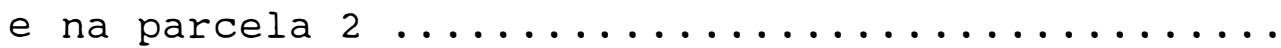

5. Valores dos coeficientes gama, "a", coeficiente linear da equaçāo (3) e condutividade hidráulica do solo saturado estimada pelo método de Libardi et alii. Valores individuais e médios

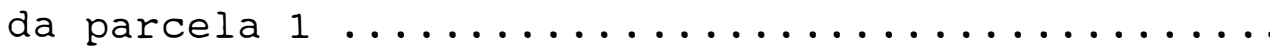

6. Valores dos coeficientes gama, "a", coeficiente linear da equaçāo (3) e condutividade hidráulica do solo saturado estimada pelo método de Libardi et alii. Valores individuais e médios

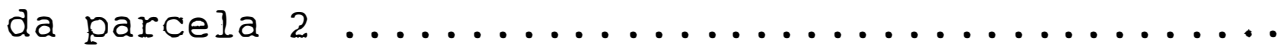

7. Lixiviação de atrazina $\left(\mu \mathrm{g} / \mathrm{m}^{2}\right)$ em profundidade, por coleta e total em cada linha das parcelas 1 e 2. L1=linha um; L2=linha dois e L3=linha $3 \ldots$ 
$x$.

8. Valores de adsorção e dessorção e ajuste feito pelo modelo de Freundlich. (A) Adsorção das amostras compostas pelos solos da parcela 1 e 2 e (B) dessorção para as mesmas amostras .............. 64 
xi.

MOVIMENTO DA ATRAZINA, DO CLORETO E DO POTÁSSIO NUMA TERRA ROXA ESTRUTURADA EUTRÓFICA

Autor: MANOEL DORNELAS DE SOUZA orientador: PROF. DR. KLAUS REICHARDT

RESUMO

o trabalho teve como objetivo estudar o movimento da atrazina, do cloreto e do potássio em Terra Roxa Estruturada eutrófica (Typic Tropudalfs) em função do deslocamento de água no perfil e do tempo de aplicação. o experimento foi instalado em duas parcelas de $7 \mathrm{~m} \times 7 \mathrm{~m}$, separadas uma da outra por $5 \mathrm{~m}$. Em cada parcela colocaram-se: nove tubos de alumínio com comprimento de $2 \mathrm{~m}$ e diâmetro interno de $3,95 \mathrm{~cm}$ para mediçōes do teor de água no solo com sonda de nêutrons nas profundidades de $20 \mathrm{~cm}, 50 \mathrm{~cm}, 100 \mathrm{~cm} \mathrm{e}$ $150 \mathrm{~cm}$; nove baterias de tensiômetros, cada uma composta por seis tensiometros nas profundidades de $35 \mathrm{~cm}, 65 \mathrm{~cm}, 85 \mathrm{~cm}$, $115 \mathrm{~cm}, 135 \mathrm{~cm}$ e $165 \mathrm{~cm}$; e nove baterias de extratores de solução do solo, cada uma composta por quatro extratores nas profundidades de $20 \mathrm{~cm}, 50 \mathrm{~cm}, 100 \mathrm{~cm}$ e $150 \mathrm{~cm}$.

$\mathrm{Na}$ parcela 1 aplicaram-se 1.000kg de calcário/ha e 500kg de gesso/ha para elevar a percentagem de 
saturação de bases para $88 \%$

Foram determinadas a condutividade hidráulica do solo saturado pelo método dos anéis e a do solo não saturado pelo método de Libardi et alii (1980).

A atrazina foi aplicada na dosagem de 12 l/ha (6kg do princípio ativo/ha) e o cloreto de potássio na dose de $204 \mathrm{~kg} / \mathrm{ha}$. Durante o período de coleta procurou-se manter - teor de água do solo acima da capacidade de campo, com aplicação de água via irrigação.

Houve intensa lixiviação da atrazina em todo o perfil do solo da parcela 1 , atingindo a profundidade de $150 \mathrm{~cm}$ sete dias após a aplicação; na parcela 2 houve perdas maiores do que na parcela 1. Também ocorreu lixiviação acentuada de potássio e cloreto nas duas parcelas. Após cinco dias da aplicação (primeira coleta) foram encontrados potássio e cloreto a $150 \mathrm{~cm}$ de profundidade em concentraçōes maiores que na testemunha.

Os resultados permitiram concluir que a aplicação de atrazina em Terra Roxa Estruturada com teor de água e pH elevados pode levar a perdas significativas do herbicida, atingindo regiōes fora do alcance das raízes, com consequiente risco de contaminação do lençol freático. 
MOVEMENT OF ATRAZINE, CHLORIDE AND POTASSIUM IN TYPIC

TROPUDALFS SOIL

Author: MANOEL DORNELAS DE SOUZA Adviser: PROF. DR. KLAUS REICHARDT

SUMMARY

This work had in view the determination of the movement of atrazine, chloride and potassium in a "Terra Roxa Estruturada" soil (Typic Tropudalfs), trying to understand the conditions that promote their transport in the soil profile. The experiment was carried out in two $7 \mathrm{~m} \times 7 \mathrm{~m}$ plots, $5 \mathrm{~m}$ apart. Each plot was instrumented with:

- 9 aluminum tubes of $3.95 \mathrm{~cm}$ internal diameter, for neutron probe soil water content measurements at the depths of $20 \mathrm{~cm}$, $50 \mathrm{~cm}, 100 \mathrm{~cm}$, and $150 \mathrm{~cm}$;

- 9 sets of $\mathrm{six}$ tensiometers installed at the depths of $35 \mathrm{~cm}$, $65 \mathrm{~cm}, 85 \mathrm{~cm}, 115 \mathrm{~cm}, 135 \mathrm{~cm}$ and $150 \mathrm{~cm}$;

- 9 sets of four soil solution extractors, installed at the depths of $20,50,100$ and $150 \mathrm{~cm}$.

The first plot received $1.000 \mathrm{~kg}$ lime/ha and $500 \mathrm{~kg}$ gypsum/ha in order to increase the soil base saturation to $88 \%$. The second was maintained without treatment.

The saturated soil hydraulic conductivity was 
xiv.

determined by means of infiltration rings, while the unsaturated was determined by the method of Libardi et al. $(1980)$.

Atrazine was applied to both plots at a rate of $12 \mathrm{l} / \mathrm{ha}$ ( $6 \mathrm{~kg}$ of active product/ha) and the potassium chloride at the rate of $204 \mathrm{~kg} / \mathrm{ha}$. During the sampling period, the soil remained under natural conditions and eventually submitted to irrrigation.

The results showed high leaching of atrazine in the first plot, reaching the depth of $150 \mathrm{~cm}$ seven days after application. For the second plot, the leaching values were higher. Pronounced potassium and chloride leaching also occurred in both plots. Five days after application (first sampling), potassium and chloride were found at the depth of $150 \mathrm{~cm}$ in concentrations higher than the control.

These results allow to conclude that the atrazine application in this soil, with both high $\mathrm{pH}$ and water content, can lead to significant losses of the herbicide below soil root zone, and hence, potentially contaminating the water table. 
1. INTRODUÇÃO

Os herbicidas são aplicados basicamente de duas maneiras: diretamente sobre o solo, antes da emergência das ervas daninhas, e sobre as ervas. Neste último caso, parte do produto aplicado também atinge diretamente a superfície do solo, outra parte chega ao solo pela morte da planta e sua decomposição, e outra parte atinge o solo escoando pela superficie das folhas.

No Brasil estuda-se muito pouco o que ocorre com os herbicidas no solo após sua aplicação. Estes apresentam um comportamento bastante complexo no solo, que é resultante de numerosas interações com os constituintes das diferentes fraçōes do solo. Os minerais de argila e materiais húmicos são os principais responsáveis pelo processo de adsorção de herbicidas. Este processo está relacionado ao transporte, absorção e bioatividade do herbicida .

O herbicida escolhido foi a atrazina (2cloro-4 etilamino-6 isopropilamino-s triazina) da familia das triazinas, bastante empregado em culturas de milhose cana de açúcar, e bastante estudado fora do Brasil. Apresenta uma solubilidade em água de $70 \mathrm{mg} / \mathrm{l}$ e $D_{L_{0}}>3.000 \mathrm{mg} / \mathrm{kg}$, e sua 
presença em águas de chuva e lagos tem sido registrada por alguns autores.

Sua absorção pelo organismo de animais é rápida. Dados de revisão da divisão de pesticidas do departamento de água potável dos EUA mostram que pelo menos $80 \%$ da dose de $0,53 \mathrm{mg}$ ministrada em ratos foi absorvida em 72 horas e as maiores concentraçōes foram observadas no fígado, rim e pulmão do animal. O mesmo departamento cita casos de contaminação de um homem que esteve por período de tempo curto em contato com o produto, registrando inchaço, bolhas e ruborização das mãos.

Este estudo faz parte do projeto temático "Transporte, previsão do destino e balanço de pesticida no solo", processo número 90/3773-7 financiado pela FAPESP e nele enfatizou-se, principalmente, o transporte ou deslocamento do herbicida no solo, buscando-se determinar, em função do movimento de água no perfil e do tempo de aplicação, a que profundidade chega o herbicida, e se isso oferece riscos de contaminação de águas percoladas para profundidades maiores, que contribuirão para recarga do lençol freático.

Além da atrazina, também estudou-se o movimento dos íons cloreto e potássio no solo para verificar se os mesmos estão correlacionados com o movimento do herbicida; procurou-se ainda, verificar se os íns cloreto e potássio podem ser utilizados na predição da dinâmica de herbicidas já 
que esses produtos podem apresentar caráter cationico ou aniônico. 
2. REVISÃO DE LITERATURA

2.1. Atrazina no solo

Ao entrar em contato com o solo, o destino e o comportamento de um pesticida depende, segundo BAILEY et alii (1968) de sete aspectos: (1) decomposição química; decomposição fotoquímica; (3) decomposição microbiológica; (4) volatilização; (5) movimento no perfil; (6) absorção pelas plantas, e (7) adsorção. ANDERSON (1983) agrupou estes fatores em três processos: químico, físico e biológico. No processo físico o pesticida é afetado pela erosão, lixiviação e volatilização. No processo biológico ocorre a decomposição por ação dos microorganismos, e no processo químico ocorre adsorção, troca iônica, decomposição fotoquímica e reaçōes químicas com os constituintes do solo.

Nesta revisão serão enfatizados, principalmente, o movimento no perfil e a adsorção; esta última parece ser um dos fatores que mais afeta as interações dos colóides do solo com os herbicidas.

A atrazina é classificada como um herbicida de caráter básico (BAILEY et alii, 1968) e, portanto, pode ser adsorvida pelas argilas pelo processo de adsorção catiônica. 
As moléculas dos herbicidas de caráter básico têm tendência, segundo WEBER (1972) e WEED \& WEBER (1974) de receberem o íon hidrogênio e ficarem protonadas. Segundo WEBER (1972) a atrazina pode receber o íon hidrogênio no nitrogênio do anel heterocíclico, ficando protonada. Este processo depende do pH da solução e um decréscimo do $\mathrm{pH}$ a valores próximos do pKa do herbicida resulta em protonação da molécula com conseqüente aumento do seu caráter catiônico. Segundo BAILEY et alii(1968), um composto básico está 10\% associado quando o pH é uma unidade maior do que $\circ \mathrm{pK}$ e $90 \%$ associado quando $\circ \mathrm{pH}$ é uma unidade menor do que o pk, e está $100 \%$ associado ou completamente dissociado quando $\circ \mathrm{pH}$ é aproximadamente duas unidades abaixo ou acima do pka, respectivamente. Como a atrazina tem pKa de 1,68, BAILEY et alii (1968) esperavam que menos de $10 \%$ da atrazina fosse adsorvida numa suspensão de argila com pH de 3,35; no entanto, houve adsorção completa, - que levou os autores a concluírem que $0 \mathrm{pH}$ na superfície da argila encontrava-se pelo menos três unidades abaixo do pH da suspensão. Condições de baixo pH afetam também a hidrólise química da atrazina para hidroxiatrazina, que é inativa (WEBER, 1970). Segundo EVANGELOU \& WANG (1993) o mecanismo de adsorção de atrazina e outras cloro-triazinas pelas argilas e o processo de hidrólise seguem o esquema a seguir: 


\section{Chloro-otrozine}

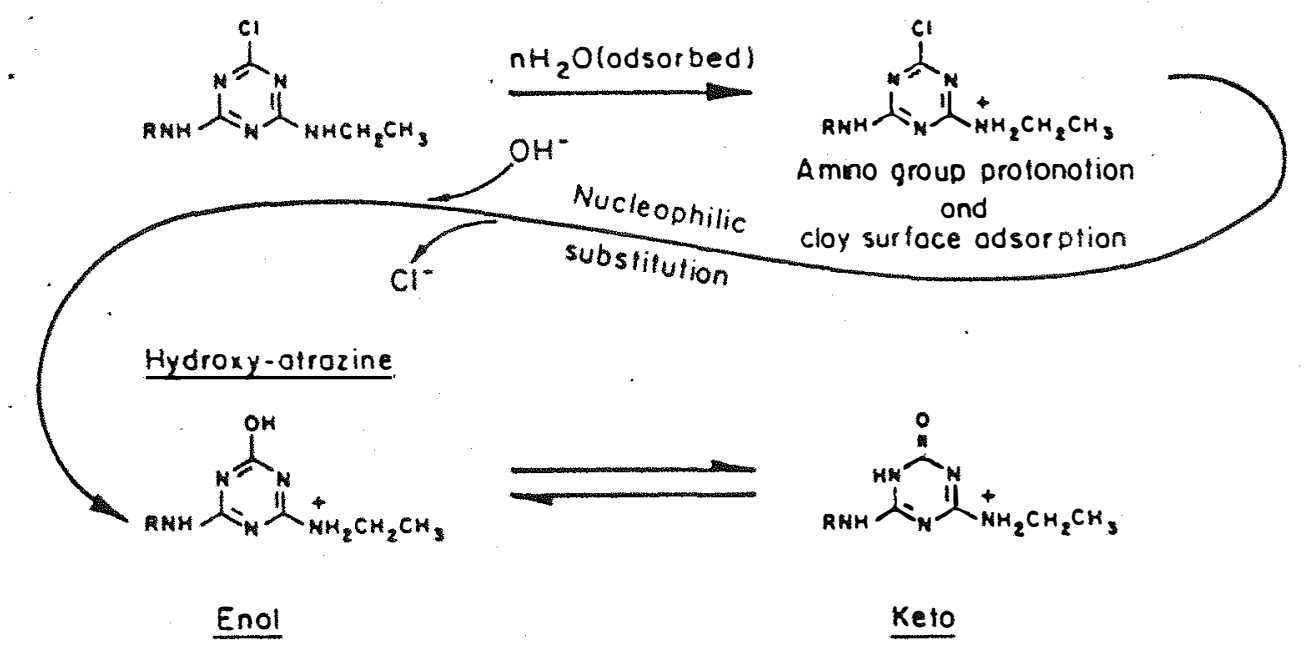

$\left[\begin{array}{ll}\mathrm{C} & \mathrm{CH}_{3}>\mathrm{CH} \cdot \\ & \mathrm{CH}_{3} /\end{array}\right]$

ARMSTRONG \& KONRAD (1986) apresentaram o modelo abaixo como proposta de hidrólise das cloro-triazinas por reação com grupos carboxílicos protonados da matéria orgânica do solo:

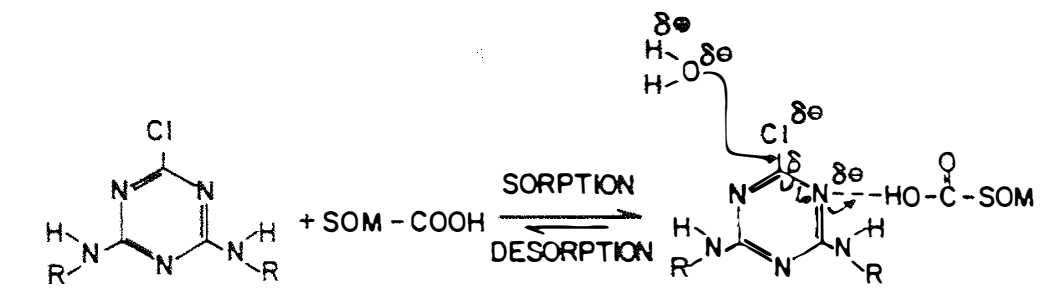

CHLORO-S-TRLAZINE (SORBED)

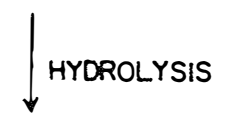<smiles>[Y]C1NC(O)=NN([R])N1</smiles>

HYDROXY-S-TRIAZINE

$+\mathrm{SOM}-\mathrm{COOH}$

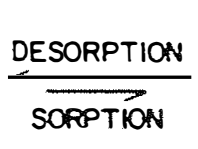

HYDROXY-S-TRIAZINE(SORBED)

SOM-COOH = CARBOXYL FUNCTIONAL GROUP ON SOIL ORGANIC MATTER. 
KAUFMAN (1986) apresentou o esquema abaixo como os caminhos de degradação microbiológica das cloro-triazinas onde no caso da atrazina $\mathrm{R}_{1}=\mathrm{C}_{3} \mathrm{H}_{7}$ e $\mathrm{R}_{2}=\mathrm{C}_{2} \mathrm{H}_{5}$ :

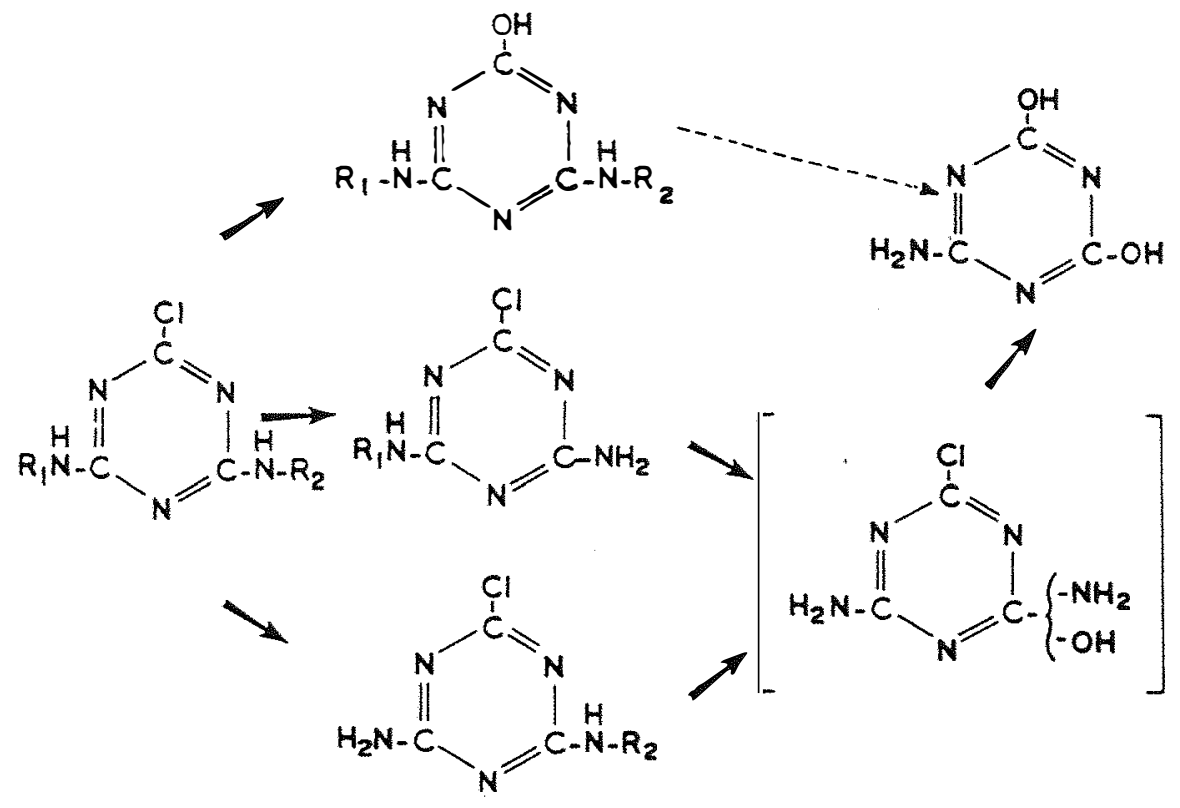

HARRIS \& WARREN (1964) estudaram a adsorção e dessorção de alguns herbicidas pelo solo e verificaram que, além do pH, a temperatura influencia bastante a adsorção dos herbicidas. Para $\circ \mathrm{pH}$, o maior efeito foi sobre $\operatorname{DNBP}(4,6-$ dinitro-o-sec-butylphenil) e atrazina. A diminuição da temperatura aumenta a adsorção da atrazina em solos e argilas e, segundo estes autores, não foi encontrada influência para solos orgânicos. Efeito semelhante para solos orgânicos do Havaí foi encontrado por YAMANE \& GREEN (1972).

A adsorção da atrazina e outras triazinas nas superfícies de argilas e colóides orgânicos reduz suas 
concentraçōes na solução do solo, diminuindo suas disponibilidades e também seus movimentos no solo. Segundo HARRIS et alii (1968) os herbicidas da familia triazina diferenciam-se entre si quanto à adsorção no solo sendo observado para muitos solos que: propazina < atrazina < simazina < prometona < prometrina. BAILEY et alii (1968) estudaram a adsorção de herbicidas orgânicos pela montmorilonita e verificaram que a solubilidade em água dos herbicidas da familia triazina foi diretamente correlacionada com $O$ valor $K$ da equação de Freundlich utilizado pelos autores como critério de adsorção quando a concentração da solução de equilíbrio é igual a 1 , excetuando-se apenas a atrazina.

HUANG et alii (1984) estudaram a importância relativa dos sesquióxidos de ferro e alumínio, da matéria orgânica e de uma série de fraçōes de diferentes tamanhos de partículas na adsorção de atrazina e observaram que, ao lado das partículas de minerais de argila, os sesquióxidos do solo tiveram uma grande capacidade de reter o produto, uma vez que, após a destruiçao da matéria orgânica, a remoção dos sesquióxidos por tratamento com ditionito-citrato-bicarbonato de sódio causou uma redução substancial na intensidade de adsorção do herbicida. Para a matéria orgânica, DUNIGAN \& McINTOSH (1971) verificaram, em solo franco siltoso, que a atrazina foi adsorvida na razão de $77,5 \mu \mathrm{g} / \mathrm{g}$ e que, quando removeram a matéria orgânica do solo $(2,5 \%)$, a adsorção caiu 
para $40 \mu \mathrm{g} / \mathrm{g}$.

RAHMAN \& MATTHEWS (1979) estudaram o efeito do conteúdo de matéria orgânica sobre 13 herbicidas da família triazina em três solos franco arenosos e concluíram que, em geral, os compostos com maior solubilidade em água foram menos influenciados quanto à fitotoxicidade pelo conteúdo de matéria orgânica quando comparados com compostos de menor solubilidade. Ao estudarem a persistência desses herbicidas, verificaram que as clorotriazinas foram as que apresentaram maior longevidade. A esse respeito, SMITH \& WALKER (1989) estudaram a persistência de alguns herbicidas em solo argiloso e verificaram que em condições de laboratório, a meia vida da atrazina passou de 44 dias com umidade do solo de $34 \%$ e temperatura de $30^{\circ} \mathrm{C}$ para 206 dias com a mesma umidade e temperatura de $5^{\circ} \mathrm{C}$. Quando variaram a umidade e mantiveram constante a temperatura em $20^{\circ} \mathrm{C}$, a meia vida da atrazina no solo passou de 56 dias com $34 \%$ de umidade para 338 dias com $8 \%$ de umidade do solo.

REINHARD et alii (1990) relacionaram a persistência da atrazina com algumas propriedades de dez solos e verificaram que 35 dias após a aplicação houve alta correlação direta entre a bioatividade do herbicida com o teor de carbono orgânico. Seis meses após a aplicação houve ainda alta correlação direta com o teor de carbono orgânico e com o pH do solo e baixa correlação com argila e CTC. A persistência do herbicida foi correlacionada negativamente 
com a percentagem de carbono e positivamente com o pH do solo. Os autores relataram ainda que na África do sul a persistência da atrazina sob condições de campo é, com frequência, superior a 12 meses; no entanto, em parte dos solos que estudaram, houve dissipaçao completa da atrazina em um ano.

Apesar de uma série de fatores do solo influenciarem a adsorção da atrazina, sua lixiviação no solo pode ser bastante significativa. Estudos em condições de campo e laboratório têm mostrado os riscos de contaminação do meio por este produto pois, segundo GREEN \& OBIEN (1969), nos solos com baixa capacidade de adsorção, variações no conteúdo de água alteram significativamente a concentração do herbicida na solução do solo. o principal efeito do conteúdo de água sobre a fitotoxicidade do herbicida está provavelmente asssociado com o transporte do herbicida no perfil. BACCI et alii (1989) verificaram que em um perfil de solo analisado 130 dias após a aplicação de 2 kg de atrazina/ha, o produto foi encontrado em todas as camadas analisadas até a profundidade de $320 \mathrm{~cm}$.

SMITH et alii (1992) estudaram a lixiviação de atrazina através de colunas com $115 \mathrm{~cm}$ de comprimento por $19,1 \mathrm{~cm}$ de diâmetro contendo solo franco arenoso com estrutura indeformada e em capacidade de campo. Foi utilizada uma solução de atrazina na razão de $3,3 \mathrm{~kg} / \mathrm{ha}$, marcada com carbono 14. Quatro horas após a aplicação da atrazina, 
aplicaram $35 \mathrm{~mm}$ de água num período de 30 minutos e 20 minutos após fizeram a primeira medida e encontraram 0,2ppb de atrazina a mais de $80 \mathrm{~cm}$ de profundidade numa das colunas, enquanto que nas outras a concentração de atrazina ficou em $0,1 \mathrm{ppb}$. Como o principal mecanismo de transporte de atrazina no solo é por fluxo de massa na fase aquosa (GUTH et alii, 1977), os autores acima associaram o rápido movimento da atrazina na coluna a esse mecanismo. outro fator que parece influenciar no deslocamento da atrazina no perfil é a presença de raízes. ZINS et alii (1991) estudaram o efeito da presença de raízes de alfafa sobre o movimento de atrazina e alaclor em colunas contendo solo siltoso e verificaram que a presença de raízes facilitou o movimento dos pesticidas; atribuiram o fato ao surgimento de macroporos devido ao crescimento das raízes.

BACCI et alii (1989) estudaram o efeito da atrazina no ambiente e concluíram que a atrazina, bem como outros compostos químicos de propriedades similares, podem ser considerados como compostos de alto potencial de contaminação de corpos aquosos. Os mesmos autores relataram que na Itália uma única aplicação de atrazina (1 kg/ha) em uma lavoura de milho com 100ha, foi suficiente para contaminar um lago contendo 10 milhōes de metros cúbicos de água, localizado próximo da plantação. A concentração de atrazina encontrada na água do lago foi superior a 1ppb, valor 10 vezes maior que o limite de 0,1ppb estabelecido por 
uma lei de 1986 para água potável, naquele país. A água era utilizada por 8.000 habitantes da área e o tratamento convencional da mesma não mudou a concentração da atrazina. BUSER (1990) verificou que em 18 lagos analisados na suíça havia resíduos detectáveis de herbicidas da família triazina, sendo que a atrazina foi o herbicida presente em maior concentração. Águas de chuva de diferentes localidades na suíça também foram analisadas e verificou-se contaminação de atrazina de até $0,6 \mathrm{ppb}$ em uma das regiões.

No caso de solos brasileiros, onde predomina a caulinita, a capacidade de adsorção é menor do que em solos com argila 2:1. Isto deve facilitar o processo de lixiviação do herbicida no perfil do solo (DACHLER, 1978), pois quanto menores forem a capacidade de adsorção do solo, e o teor de matéria orgânica e/ou argila do solo, maior será a lixiviação prevista, principalmente nos solos com teor de umidade próximo da capacidade de campo.

2.2. Potássio e cloreto no solo

A utilização de íons como traçadores para estudar o movimento de água e sais solúveis no solo tem sido empregada apesar da repetitividade da distribuição dos íons no perfil não ser muito boa, pois estudos desenvolvidos por KELLER \& ALFARO (1966) indicam que a aplicação de água sob diferentes taxas durante o processo de lixiviação de sais 
solúveis levou a significativas diferenças de distribuição dos sais no perfil do solo, devido a diferentes velocidades de distribuição de água nos poros.

A influência de fendas sobre a condutividade hidráulica do solo saturado, em solos com características expansivas, foi estudada por alguns autores que, a princípio, utilizavam o cloro e o trítio, elementos com baixa capacidade de adsorção, para indicar a profundidade atingida pela água e o modo como ela se moveu (BLAKE et alii, 1973; QUISENBERRY \& PHILIPS, 1976), mas o traçador químico oferecia algumas dificuldades de amostrageme, principalmente, não era visível no perfil. BOUMA et alii (1977) apresentaram como solução a utilização de uma solução contendo azul de metileno que tingia os poros por onde passava, e deixava desenhada no perfil a configuração de avanço da frente de molhamento.

Mas, segundo EVANS \& LEVIN (1968), a distribuição de sais no perfil pela água de infiltração sob condições de insaturação é diferente do processo de distribuição de íons no perfil sob condições de saturação. No caso de solo insaturado, a frente de molhamento vai na frente e o pico de sais se move consideravelmente atrás. Para um dos solos estudados (franco argiloso), os autores observaram que a frente de molhamento estava a $50 \mathrm{~cm}$ de profundidade e o pico de cloreto estava a $24 \mathrm{~cm}$ de profundidade. 0 mesmo comportamento foi observado para o ion sulfato (SQ).

o movimento de íons no perfil do solo também 
está sujeito ao processo de adsorção, difusão, fluxo de massa e, no caso do potassio, também à fixação por alguns minerais. Assim, encontra-se na literatura que para alguns solos o potássio é bastante móvel e para outros pouco móvel, o mesmo ocorrendo com o íon cloreto.

FRANCO \& MEDINA (1960) aplicaram cloreto de potássio na razão de $180 \mathrm{~g} / 10 \mathrm{~m}$ de sulco para uma plantação de café localizada em Latossolo Vermelho-amarelo de textura arenosa e em Terra Roxa de textura argilosa e observaram intensas perdas de potássio a partir do segundo ano até a profundidade de $100 \mathrm{~cm}$. SUAREZ \& CARRILLO (1984) estudaram O comportamento de três fertilizantes potássicos aplicados em 400 gramas de solo (Dystrandept Tipico) com densidade de 0,62 $\mathrm{g} / \mathrm{cm}^{3}$ acondicionado em tubos de PVC e verificaram que para o cloreto de potássio, após passarem nove vezes um volume de $25 \mathrm{ml}$ de água por vez pelo solo, a perda de potássio foi de $94 \%$ e a do cloreto de apenas 39,9\%. Já num experimento em colunas, BORROTO et alii (1988) estudaram a mobilidade do íon potássio e verificaram que a lixiviação ocorreu até $30 \mathrm{~cm}$ de profundidade e foi influenciada pela dose aplicada e pelos intervalos de irrigação, sendo que o menor intervalo (três dias) foi o que propiciou a maior movimentação de potássio no solo.

PHILLIPS et alii (1988) verificaram, para solos de carga variável da Nova Zelândia, que a elevação do pH do solo diminuiu as perdas de potássio e magnésio por lixiviação 
depois que o solo foi corrigido. O aumento na CTC foi responsável pela diminuição nas perdas. Verificaram também que as perdas de potássio e magnésio inicialmente presentes no solo aumentaram quando aplicaram hidróxido de cálcio em condiçōes de saturação. JADCZUK \& ZMUDZIN (1990) verificaram que em um solo franco siltoso da Polônia houve baixa lixiviação de potássio, mesmo para a dose mais alta $(1.600 \mathrm{~kg}$ de $\mathrm{K}_{2} \mathrm{O} / \mathrm{ha}$ ) associada com um aumento na lâmina de irrigação de $490 \mathrm{~mm} / a n o$ para $1.000 \mathrm{~mm} / \mathrm{ano}$. Os autores atribuíram o fato a uma possível fixação do potássio pelos minerais de argila presentes naquele solo, com conseqüente diminuiçao no potássio trocável.

Por outro lado, CILLMAN et alii (1989) estudaram a lixiviação de cálcio e potássio em um oxissolo da Austrália de textura argilosa e verificaram que o potássio foi bastante móvel no perfil. Dois dias após uma irrigação de $55 \mathrm{~mm}$, o potássio moveu-se além de $25 \mathrm{~cm}$ de profundidade, e com 30 dias o potássio encontrava-se distribuído até $50 \mathrm{~cm}$ de profundidade. Os autores mediram a variação de umidade no perfil a cada dois dias após cada irrigação e verificaram que a água moveu-se rapidamente no perfil até um metro de profundidade. Além disso, os autores analisaram a condutividade hidráulica e eletrolítica do solo e concluíram que estes dois parâmetros podem ser utilizados para explicar o movimento de água e solutos no perfil.

FERREIRA et alii (1990) estudaram o movimento 
vertical de cloreto e potássio em colunas com $120 \mathrm{~cm}$ de comprimento por $15 \mathrm{~cm}$ de diâmetro contendo solo argiloso sob condiçōes insaturadas. Verificaram que, independentemente do teor de umidade na superfície e da distribuição de umidade no perfil, na coluna que recebeu maior volume de água a dispersão de cloreto foi maior. Houve intensa lixiviação do íon cloreto abaixo de $80 \mathrm{~cm}$, e a redução brusca da concentração de cloreto observada entre 4 e 48 horas foi atribuída ao fluxo de massa, em virtude da quase saturação do meio poroso. Para o potássio, os autores verificaram maior concentração na profundidade de $32 \mathrm{~cm}$, quatro horas após a primeira irrigação; depois disso, não houve aumento da concentração do íon com a profundidade e com o tempo.

$$
\text { NASCIMENTO FILHO et alii (1979) estudaram o }
$$

deslocamento miscível do íon cloreto em uma Terra Roxa Estruturada localizada na mesma área experimental em que foi realizado este trabalho, e verificaram que a adsorção do íon cloreto foi muito baixa, não diferindo significativamente da adsorção nula em quatro dos oito tratamentos. Os autores concluíram que o íon cloreto pode ser utilizado como traçador em estudos de movimentação de água nesse solo. Além disso, os autores observaram pela análise de cloreto e potássio que, em um dos coletores a infiltração estava muito anormal e atribuiram o fato a uma infiltração preferencial causada possivelmente pelas rachaduras presentes no solo pelos orifícios feitos para introduzir os extratores ou 
tensiômetros.

Por outro lado, RAIJ (1986) afirma que o potássio é retido na forma iônica $\mathrm{K}^{+}$pelas cargas negativas do solo, e a lixiviação só ocorre se a água, ao percolar através do solo, arrastar ânions que por sua vez, são acompanhados de cátions para preservar a eletroneutralidade do sistema. Segundo o autor os cátions são retidos no solo na seguinte ordem: $\mathrm{Ca}^{++}>\mathrm{Mg}^{++}>\mathrm{K}^{+}>\mathrm{Na}^{+}$. Isto significa que se no início existirem quantidades equivalentes dos cátions trocáveis, as perdas serão muito maiores de sódio e de potássio em relação a cálcio e magnésio.

REICHARDT (1986) descreve o fluxo de íons no solo como sendo devido, principalmente, a dois processos: difusão, que é o movimento de íons devido ao gradiente de atividade, e fluxo de massa que é o movimento de íons arrastados pelo fluxo de água. Este último processo, denominado de transferência de massa, é fundamental na discussão deste trabalho. Se o fluxo de água é q (volume por unidade de área e de tempo), então qc é a quantidade de soluto (quantidade por unidade de área e de tempo na concentração c) transportado. Logo o fluxo "j" por transferência de massa será $j=q c$. Neste caso não é considerado o gradiente de concentração (tido como constante) e a força motora é o gradiente hidráulico que está contido no fluxo de água $q$. o valor de $q$ é dado por: 


$$
q=K(\theta) \frac{\delta H}{\delta z}
$$

onde $K(\theta)$ = condutividade hidráulica do solo não saturado que pode ser calculada pelo método de LIBARDI et alii (1980); $\frac{\delta H}{\delta z}=$ gradiente de potencial total que pode ser calculado com base em leitura de tensiômetros e $\theta$ é a umidade volumétrica do solo. 
3. MATERIAL E MÉTODOS

\section{1. Área Experimental}

\subsubsection{Localização}

A área experimental encontra-se localizada ao lado do posto meteorológico da ESALQ/USP, em Piracicaba, no Estado de São Paulo. Piracicaba encontra-se nas coordenadas geográficas de $22^{\circ} 42^{\prime}$ de latitude sul e $47^{\circ} 38^{\prime}$ de longitude oeste.

\subsubsection{Clima Regional}

No município de Piracicaba o clima é do tipo Cwa, segundo a classificação de köeppen, denominado "tropical de altitude". É um clima mesotérmico de inverno seco, em que a temperatura média do mês mais frio é inferior a $18^{\circ} \mathrm{C}$ e a do mês mais quente ultrapassa $22^{\circ} \mathrm{C}$. As médias anuais de temperatura, precipitação pluviométrica e umidade relativa são de $21,1^{\circ} \mathrm{C}, 1.257 \mathrm{~mm}$ e $74 \%$, respectivamente. A estação seca ocorre entre os meses de abril e setembro, sendo julho o mês mais seco. O mês mais chuvoso oscila entre 
janeiro e fevereiro. O total das chuvas do mês mais seco não ultrapassa $30 \mathrm{~mm}$ (SERVIÇO NACIONAL DE PESQUISAS AGRONÔMICAS, 1960)

$$
3 \cdot 1 \cdot 3 \text {. Solo }
$$

o solo que ocorre na área experimental é uma Terra Roxa Estruturada, eutrófica, textura argilosa, relevo ondulado. A área experimental foi uma área plana localizada no topo de uma ondulação. As análises químicas e granulométricas são apresentadas no item 3.2 e as respectivas metodologias no item 3.3 .2 .3 .

3.2. Descrição do experimento

o experimento foi instalado entre maio e julho de 1992 e consistiu de duas parcelas de $7 \mathrm{~m} \times 7 \mathrm{~m}$ separadas uma da outra por $5 \mathrm{~m}$ e com bordadura de 1,5m. Em cada parcela foram colocados os seguintes instrumentos:

- nove tubos de alumínio, espaçados entre si por 1,5m, com comprimento de $2 \mathrm{~m}$ e diâmetro interno de $3,95 \mathrm{~cm}$, utilizados para determinação da umidade do solo com sonda de nêutrons nas profundidades de $20 \mathrm{~cm}, 50 \mathrm{~cm}, 100 \mathrm{~cm}$ e $150 \mathrm{~cm}$;

- nove conjuntos de extratores de solução do solo com cápsula porosa para $20,50,100$ e $150 \mathrm{~cm}$ de profundidade, espaçados entre si na linha por $50 \mathrm{~cm}$ e entre linhas por 1,5m. o 
espaçamento entre extratores foi de $33 \mathrm{~cm}$;

- nove conjuntos de tensiometros para 35, 65, 85, 115, 135 e $165 \mathrm{~cm}$ de profundidade, espaçados entre si, na linha, por $50 \mathrm{~cm}$ e entre linhas por $1,5 \mathrm{~m}$, sendo 0 espaçamento entre tensiômetros de $20 \mathrm{~cm}$ (Figura 1).

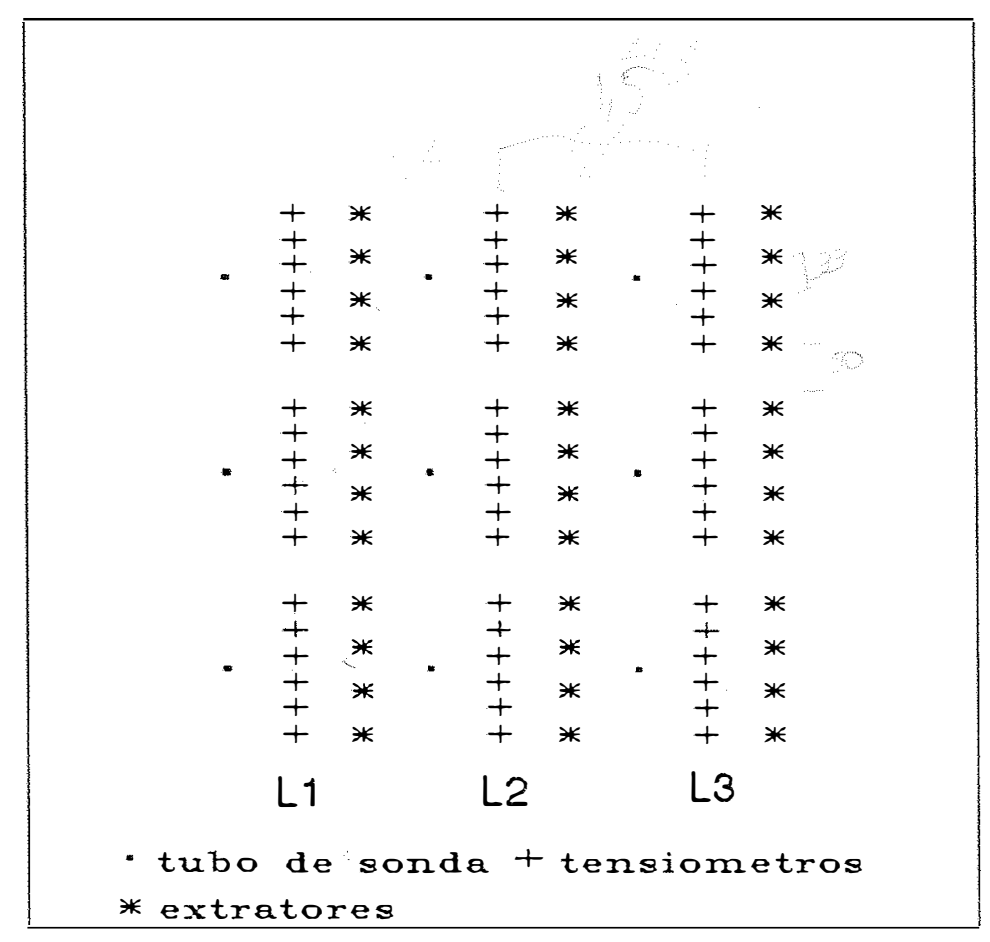

Figura 1. Esquema de uma das parcelas experimentais, indicando a distribuição de tubos, tensiômetros e extratores de solução. LI = linha 1, L2 = linha 2 e L $3=$ linha 3 .

As parcelas foram delimitadas por camalhões para facilitar a inundação (Figura 2).

Os resultados da análise química das duas parcelas podem ser vistos na Tabela 1 e os da granulometria 


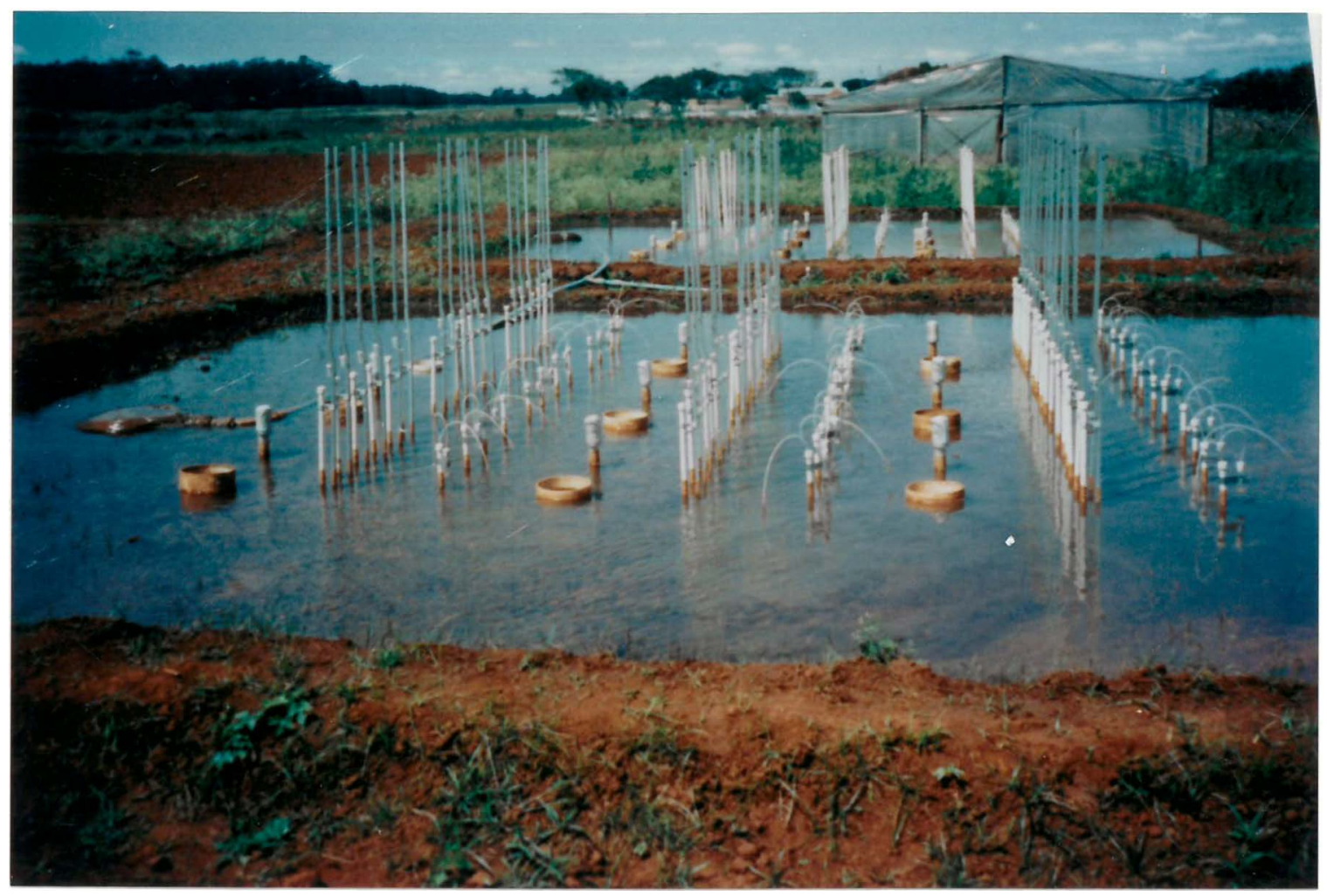

Figura 2. Disposição das parcelas no campo mostrando deta lhes da colocação dos anéis para determinação da condutividade hidráulica saturada.

na Tabela 2. A análise química foi efetuada com amostras coletadas antes da aplicação do calcário.

$\mathrm{Na}$ parcela 1 foi aplicado calcário (1.000 kg/ha) para elevar a percentagem de saturação por bases para $88 \%$, e $500 \mathrm{~kg} / \mathrm{ha}$ de gesso. Este procedimento visou a criação de uma condição de solo que deveria facilitar a lixiviação da atrazina.

o corretivo utilizado foi a cal dolomitica 
Tabela 1. Análise química do solo nas diferentes profundidades das parcelas 1 e 2 .

\begin{tabular}{|c|c|c|c|c|c|c|c|c|}
\hline prof. $p$ & gua & $\mathrm{Cl}_{2}$ & $\mathrm{H}+\mathrm{Al}$ & $\mathrm{Ca}$ & $\mathrm{Mg}$ & K & $P$ & MO \\
\hline$(\mathrm{cm})$ & \multicolumn{6}{|c|}{$\begin{aligned} 0 & \text { me/dl } \\
& \text { parcela } 1\end{aligned}$} & $(\mathrm{ppm})$ & $(8)$ \\
\hline $0-15$ & 5.98 & 5.10 & 1.90 & 4.24 & 1.07 & 0.51 & 68.90 & 2.70 \\
\hline $15-30$ & 5.95 & 5.03 & 1.70 & 3.55 & 0.87 & 0.33 & 28.00 & 1.62 \\
\hline $30-45$ & 6.14 & 5.40 & 1.40 & 3.52 & 0.90 & 0.23 & 19.70 & 1.08 \\
\hline $45-60$ & 6.28 & 5.63 & 1.40 & 3.54 & 0.95 & 0.23 & 21.50 & 0.72 \\
\hline $60-75$ & 6.35 & 5.70 & 1.30 & 3.40 & 0.87 & 0.21 & 25.10 & 0.72 \\
\hline $75-90$ & 6.38 & 5.76 & 1.30 & 3.44 & 0.84 & 0.20 & 23.30 & 0.54 \\
\hline $90-105$ & 6.38 & 5.81 & 1.30 & 3.08 & 0.75 & 0.21 & 20.10 & 0.18 \\
\hline $105-125$ & 6.45 & 5.87 & 1.20 & 2.96 & 0.73 & 0.24 & 15.40 & 0.72 \\
\hline $125-145$ & 6.50 & 5.92 & 1.20 & 2.47 & 0.60 & 0.23 & 10.80 & 0.54 \\
\hline $145-165$ & 6.57 & 5.97 & 1.20 & 2.40 & 0.63 & 0.24 & 9.30 & 0.81 \\
\hline \multicolumn{9}{|c|}{ parcela 2} \\
\hline $0-15$ & 6.33 & 5.56 & 1.90 & 4.47 & 1.57 & 0.66 & 93.40 & 2.52 \\
\hline $15-30$ & 6.08 & 5.31 & 1.80 & 3.94 & 1.05 & 0.45 & 74.30 & 1.62 \\
\hline $30-45$ & 6.08 & 5.38 & 1.60 & 3.75 & 1.02 & 0.26 & 43.10 & 1.26 \\
\hline $45-60$ & 6.16 & 5.48 & 1.60 & 3.33 & 1.02 & 0.21 & 30.50 & 0.36 \\
\hline $60-75$ & 6.22 & 5.58 & 1.30 & 3.49 & 1.12 & 0.22 & 26.90 & 0.90 \\
\hline $75-90$ & 6.24 & 5.60 & 1.40 & 3.10 & 1.00 & 0.20 & 26.90 & 0.36 \\
\hline $90-105$ & 6.25 & 5.60 & 1.30 & 3.00 & 0.99 & 0.22 & 20.10 & 0.54 \\
\hline $105-125$ & 6.19 & 5.64 & 1.30 & 2.62 & 0.82 & 0.22 & 15.40 & 0.36 \\
\hline $125-145$ & 6.23 & 5.70 & 1.30 & 2.38 & 0.72 & 0.20 & 14.40 & 0.54 \\
\hline $145-165$ & 6.31 & 5.83 & 1.30 & 2.24 & 0.65 & 0.15 & 10.00 & 0.72 \\
\hline
\end{tabular}

com PRNT de $123 \%$ e a aplicação foi feita 15 dias antes da aplicação da atrazina. O calcário e gesso foram incorporados manualmente até a profundidade de $10 \mathrm{~cm}$. 
Tabela 2. Análise granulométrica e classes texturais nas diferentes profundidades das parcelas 1 e 2 .

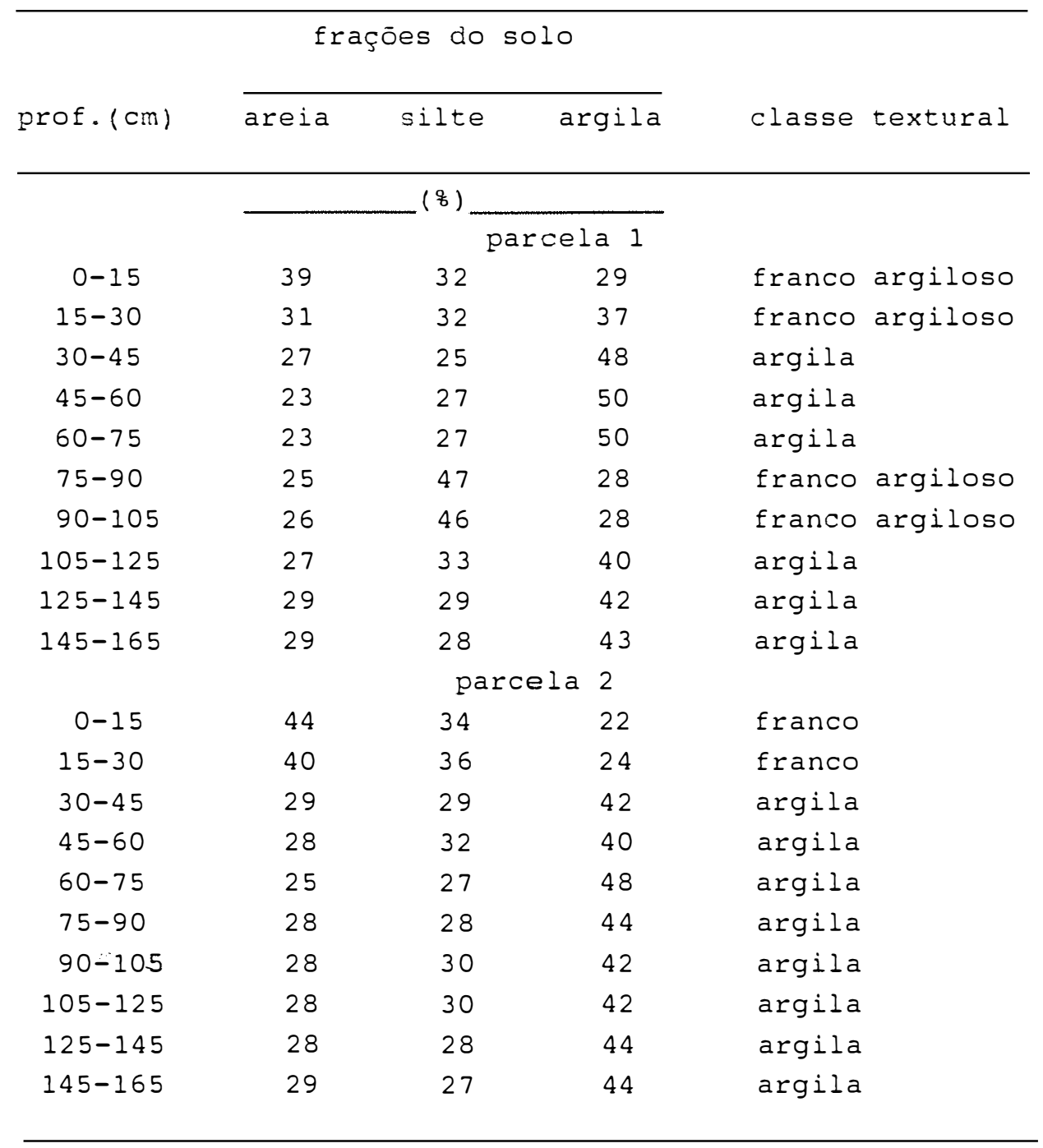

3.3. Determinaçōes e atividades

As determinaçōes ou atividades foram efetuadas em duas etapas: uma de campo e outra de laboratório, utilizando-se em laboratório as amostras de solução do solo 
coletadas no período de março a julho de 1993.

3.3.1. Determinações e atividades de campo

Foram realizados testes de condutividade hidráulica do solo saturado, utilizando-se anéis de $25 \mathrm{~cm}$ de diâmetro. Determinou-se também a condutividade hidráulica do solo não saturado e acompanhou-se a variação da umidade do solo por todo o período de condução do experimento, utilizando-se sonda de nêutrons e tensiômetros.

\subsubsection{Condutividade hidráulica do solo saturado}

Foram colocados nove anéis de $25 \mathrm{~cm}$ de diâmetro em cada parcela, distribuídos em três linhas conforme mostra a Figura 2. A condutividade hidráulica foi medida quatro vezes no decorrer do tempo, mantendo-se os anéis no mesmo lugar. A primeira determinação foi em 09/09/92, a segunda em 18/09/92, a terceira em 11/12/92 e a quarta em 02/02/93.

Antes de cada determinação as parcelas foram alagadas por um período mínimo de oito horas por dia, durante pelo menos dois dias. Monitorou-se a condição de saturação até a profundidade de $165 \mathrm{~cm}$, utilizando-se a sonda de nêtrons e os tensiômetros.

A descida da lâmina de água dentro dos anéis 
foi medida com paquímetro, e as medidas foram tomadas sempre no mesmo ponto de cada anel, a cada 10 minutos, durante duas horas.

3.3.1.2. Condutividade hidráulica do solo não saturado

Saturaram-se as parcelas no dia 03/02/93. Mediu-se a umidade de saturação $\left(\theta_{0}\right)$ com sonda de nêutrons nas profundidades de $20 \mathrm{~cm}, 50 \mathrm{~cm}, 100 \mathrm{~cm}$ e $150 \mathrm{~cm}$, mantendo-se as parcelas alagadas. Após a infiltração da lâmina, cobriu-se cada parcela com capim, para evitar perdas por evaporação, e com um plástico preto para protegê-las de eventuais chuvas ( Figura 3).

A partir do primeiro dia foram feitas leituras diárias da umidade do solo e dos tensiômetros até o oitavo dia. Os dados de umidade serviram para determinar os parâmetros da função:

$$
K(\theta)=K_{0} e^{\gamma\left(\theta-\theta_{0}\right)}
$$

onde $\mathrm{K}(\theta)$ é a condutividade do solo não saturado na umidade volumétrica $\theta, \mathrm{K}_{\mathrm{o}}$ é a condutividade do solo saturado, $\theta_{0}$ é a umidade volumétrica do solo saturado, $\theta$ é a umidade volumétrica do solo não saturado, "e" é a base do logaritmo neperiano e $\gamma$ é um parâmetro de ajuste (método de LIBARDI et 


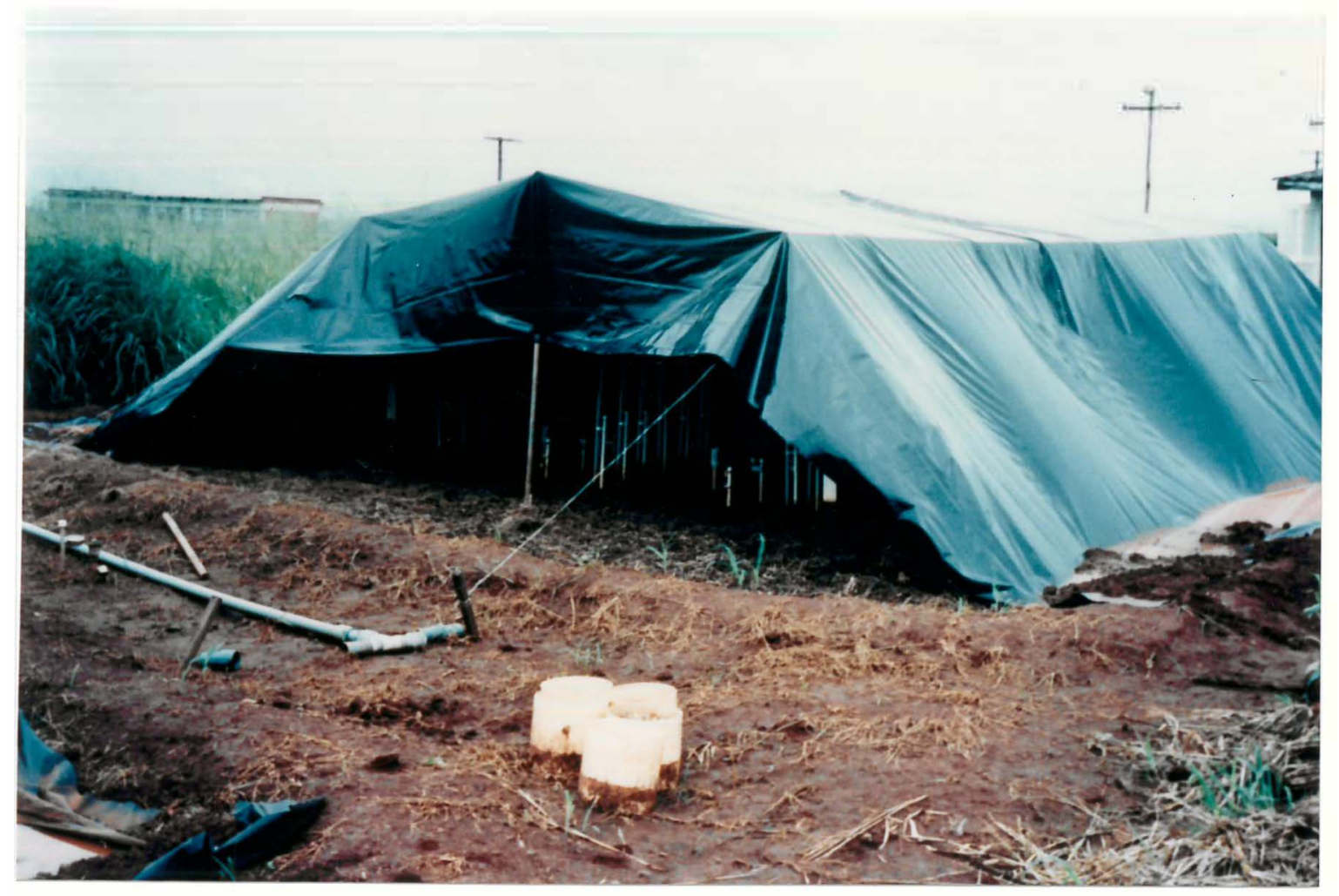

Figura 3. Detalhe da cobertura de uma das parcelas.

alii (1980)). O valor da umidade de saturação $\left(\theta_{0}\right)$ usado nos cálculos foi o medido com a sonda de nêtrons para cada profundidade.

Para determinação da função $K(\theta)$ é necessário conhecer o valor de $\gamma$, de $K_{0}$ e do coeficiente "a" a partir 
da equação:

$$
\theta_{0}-\theta=\frac{1}{\gamma} \ln t+\frac{1}{\gamma} \ln \left(\frac{\gamma K_{0}}{a z}\right)
$$

onde $\theta_{0}$ é a umidade volumétrica do solo saturado, $\theta$ é a umidade volumétrica do solo não saturado, t é o tempo, z é a profundidade, e "a" e $\gamma$ são parâmetros de ajuste do modelo. Esta equação indica que $\theta_{0}-\theta$ é linearmente relacionado com Int, sendo o coeficiente angular igual a $1 / \gamma$. O coeficiente linear representa uma medida teórica de $K_{0}$, conhecendo-se o valor de "a", definido como sendo $\gamma / \bar{\gamma}$.

o valor de $\bar{\gamma}$ é determinado pela regressão linear de $\left(\bar{\theta}_{0}-\bar{\theta}\right) \times \operatorname{lnt}$, e de $\gamma$ por $\left(\theta_{0}-\theta\right) \times$ lnt. Isto é:

$$
Y=a x+b
$$

onde $\mathrm{Y}=\left(\theta_{0}-\theta\right) ; \mathrm{x}=\ln t ; \mathrm{a}=1 / \gamma \mathrm{e} \mathrm{b}=1 / \gamma \ln \left(\gamma \mathrm{K}_{\mathrm{o}} / \mathrm{az}\right)$.

o valor de $K_{0}$ teórico pode então ser obtido pela expressão:

$$
K_{0}=e^{(b \gamma+\ln a z-\ln \gamma)}
$$

\subsubsection{Aplicação da atrazina}

A atrazina foi aplicada em 16/03/93; três dias antes, as parcelas foram alagadas por um periodo de oito horas. Este procedimento visou elevar o teor de água no solo 
para valores próximos da capacidade de campo, criando-se condições de umidade favoráveis à lixiviação do herbicida. Procurou-se manter as condições de umidade elevada por todo o período de coleta, fazendo-se irrigações. Fez-se uma coleta de solução do solo antes da aplicação de atrazina para controle no processo de análise.

Foram utilizados 12 l/ha $(6 \mathrm{~kg}$ do princípio ativo/ha), o dobro da dosagem máxima recomendada no rótulo, do herbicida GESAPRIN 500 que tem como princípio ativo a atrazina (2-cloro-4-etilamino-6-isopropilamino-s-triazina) na concentração de $500 \mathrm{~g} / \mathrm{l}$.

Em cada parcela foram utilizados $58,8 \mathrm{ml}$ (12 l/ha) do herbicida, diluídos em 4,5 litros de água. A aplicação foi feita utilizando-se pulverizador costal com capacidade para cinco litros.

Teve-se o cuidado de cobrir com sacos plásticos todas as rolhas dos extratores antes da aplicação, para evitar contaminação da solução do solo.

A primeira coleta de solução ocorreu no dia 23/03/93, a segunda em 06/04/93, a terceira em 23/04/93, a quarta em 12/05/93 e a quinta e última em 26/05/93.

A partir da aplicação da atrazina, procurou-se manter a umidade volumétrica do solo sempre próxima da saturação. Para isso, foram feitas irrigações todas as quintas-feiras, durante o período de coleta, excetuando-se as semanas com precipitação pluviométrica suficiente para manter 
alto o teor de água no solo (Figura 4). Os dados de evaporação e precipitação são da estação meteorológica que fica localizada ao lado da área experimental.

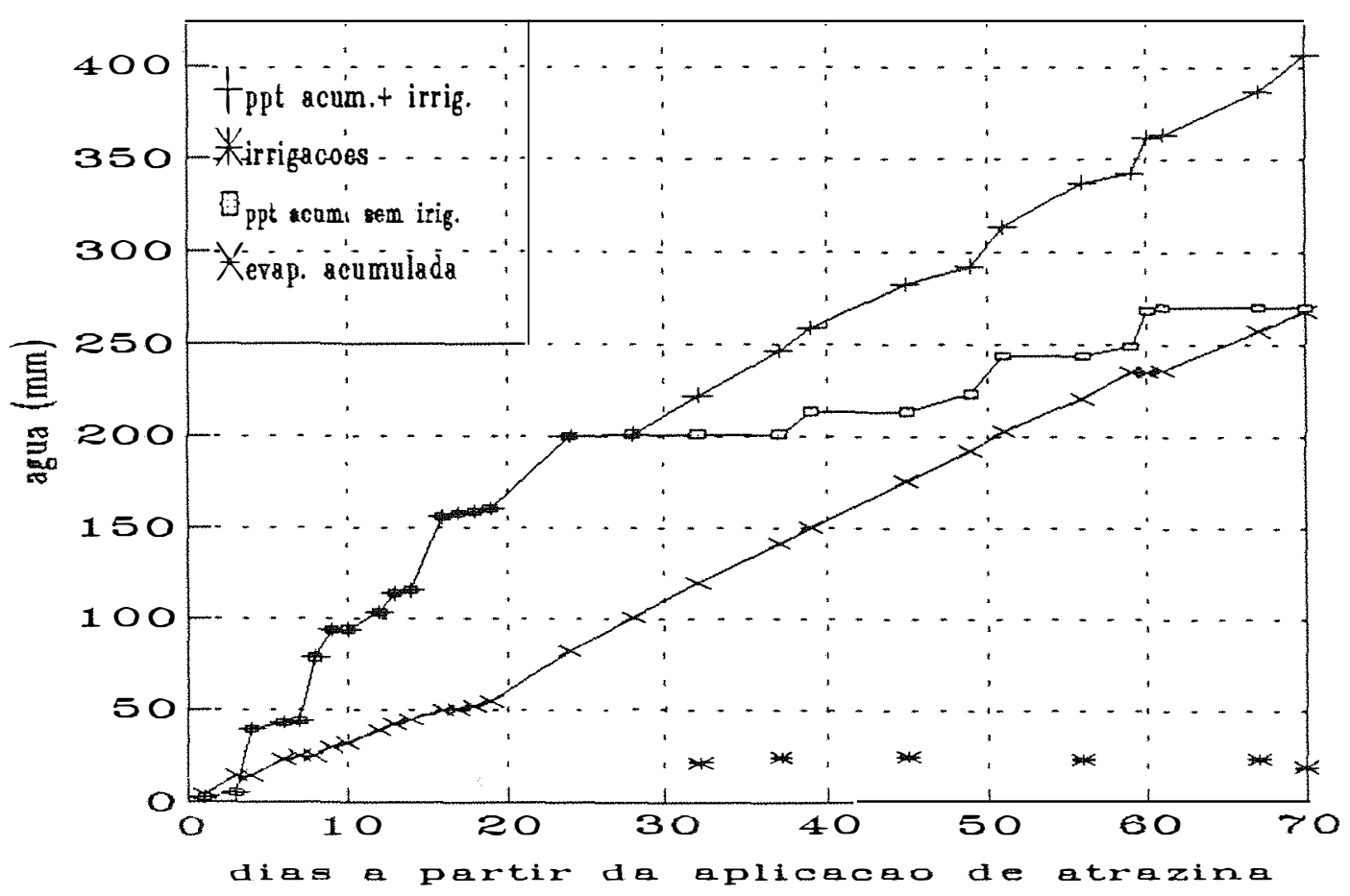

Figura 4. Evaporação acumulada, precipitação acumulada e irrigação acumulada no período de coleta de atrazina 
3.3.1.4. Aplicação do cloreto e do potássio

Adotou-se o mesmo procedimento empregado para a atrazina, porém efetuaram-se duas coletas de solução por semana. A aplicação de $1 \mathrm{~kg}$ de $\mathrm{KCl}(204 \mathrm{~kg} / \mathrm{ha}$ equivalente a $128,8 \mathrm{~kg}$ de $\mathrm{K}_{2} \mathrm{O} / \mathrm{ha}$ e $97,1 \mathrm{~kg}$ de cloreto/ha) por parcela ocorreu em 05/07/93 e a primeira coleta em 10/07/93, a segunda em 14/07/93, a terceira em 16/07/93, a quarta em 21/07/93 e a quinta em 24/07/93. O cloreto de potássio foi diluído em cinco litros de água e sua aplicação foi realizada com pulverizador costal com capacidade para cinco litros.

Na Figura 5 são apresentadas as variações da evaporação acumulada no período de coleta do cloreto e potássio e das lâminas de irrigação acumulada no mesmo período. Houve apenas uma chuva de $12,7 \mathrm{~mm}$ ocorrida dez dias após a aplicação de cloreto.

3.3.1.5. Coletas de solução do solo

- processo de coleta de solução do solo consistiu basicamente de duas etapas. Na primeira, fez-se vácuo nos extratores, um dia antes da coleta, utilizando-se bomba de vácuo elétrica com sucção de 0,6 bar. O período de vácuo por extrator foi de dois minutos. Após o vácuo, pinçouse a mangueira com pinça de Mhor. Os frascos utilizados foram vidros escuros com capacidade para $250 \mathrm{ml}$. A segunda etapa 


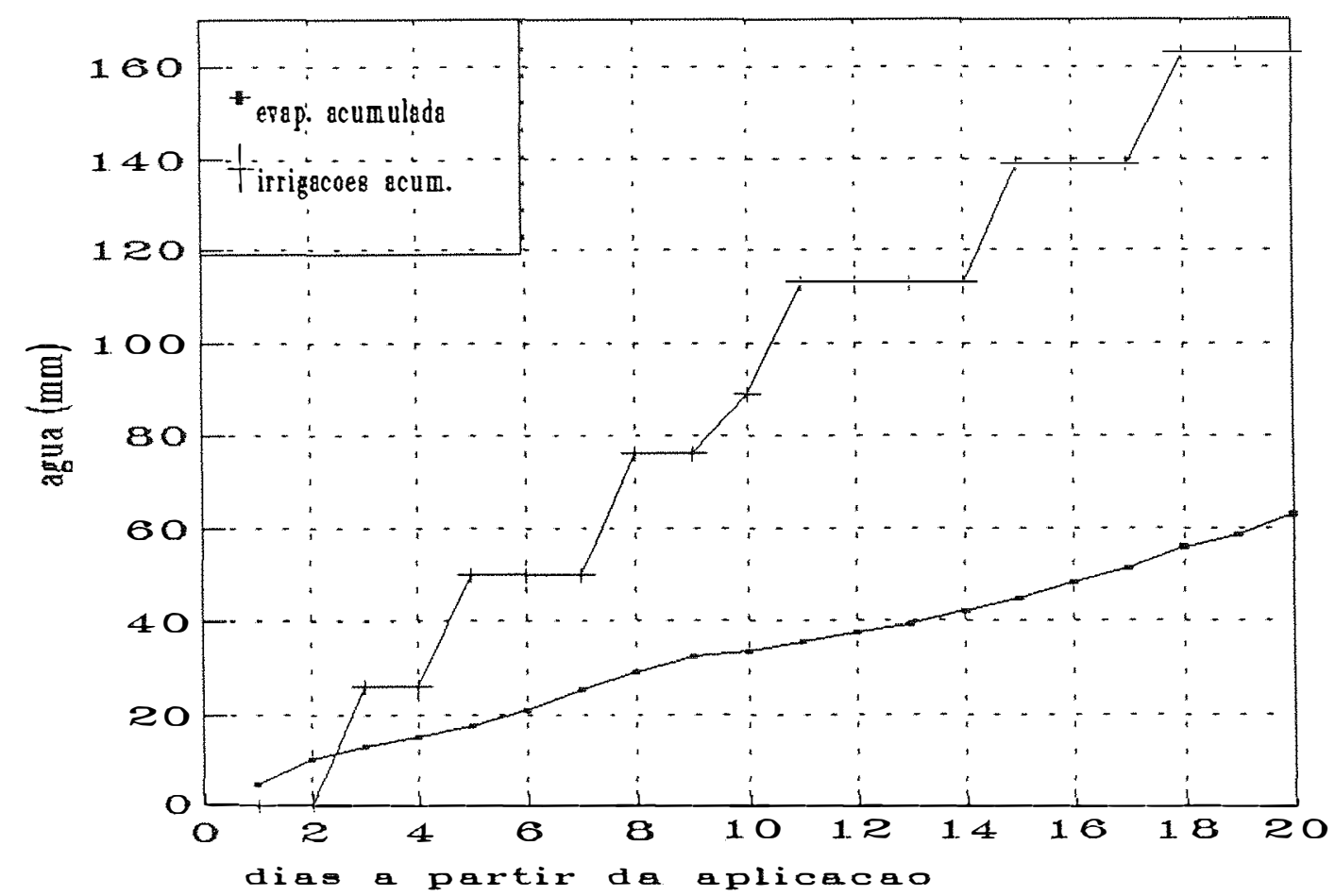

Figura 5. Evaporação e irrigação acumuladas no período de coleta de solução do solo para determinação de cloreto e potássio.

ocorreu no dia seguinte com a retirada das pinças, para que a pressão atmosférica atuasse no interior dos extratores, empurrando a solução para dentro dos frascos. Os frascos eram então tampados e levados para refrigerador.

No caso da atrazina, devido ao alto custo das análises, fizeram-se amostras compostas no seguinte esquema: conforme pode ser visto na Figura 1 , cada parcela foi constituída por três linhas de extratores, e cada linha por 
três conjuntos de extratores nas profundidades de $20 \mathrm{~cm}, 50 \mathrm{~cm}$, $100 \mathrm{~cm}$ e $150 \mathrm{~cm}$ cada um. Para fazer cada amostra composta, adicionaram-se os três volumes coletados numa mesma profundidade em um único frasco. Dessa forma, em cada linha, obtiveram-se quatro frascos de amostras compostas, perfazendo um total de 12 frascos por parcela em cada coleta.

Para $\circ \mathrm{KCl}$, coletaram-se amostras simples, 36 por vez em cada parcela, utilizando-se o mesmo procedimento de coleta. A coleta de amostras simples para o cloreto e o potássio teve como objetivo extra verificar a existência e influência de rachaduras do solo no movimento dos íons no perfil.

\subsubsection{Leitura de tensiômetros}

No período de coleta da atrazina os tensiômetros foram lidos às terças e sextas-feiras e nos dias de coleta de solução do solo; e no caso do cloreto e do potássio, nos dias de coleta. Os resultados obtidos foram utilizados para determinar os gradientes de potencial total da água no solo no período de coletas, com os quais se verificaram a direção de movimento da água no solo.

\subsubsection{Sonda de nêutrons}

As leituras com sonda de nêtrons foram feitas 
diariamente no período de determinação da condutividade hidráulica e uma vez por semana no período de coleta de solução do solo para determinação da atrazina.

As profundidades de leituras foram $20 \mathrm{~cm}, 50 \mathrm{~cm}$, $100 \mathrm{~cm}$ e $150 \mathrm{~cm}$ e a equação de calibração utilizada foi $\theta=-$ $0,00551+0,74418 \mathrm{CR}$ com $R^{2}=0,86$ feita por TURATTI et alii (1990), onde CR é a contagem relativa, obtida pela divisão da contagem feita no campo pela contagem feita na água.

Utilizou-se a sonda de nêutrons Nardeux-humisol modelo solo-25.

3.3.1.8. Coleta de amostras para análises granulométricas e químicas

As amostras de solo foram compostas por nove sub-amostras por profundidade, aproveitando-se o solo retirado nas perfurações para instalação dos tubos de acesso para sonda de nêtrons. As profundidades adotadas por parcela foram: $0-15 \mathrm{~cm} ; 15-30 \mathrm{~cm} ; 30-45 \mathrm{~cm} ; 45-60 \mathrm{~cm} ; 60-75 \mathrm{~cm} ; 75-90 \mathrm{~cm}$; $90-105 \mathrm{~cm} ; 105-125 \mathrm{~cm} ; 125-145 \mathrm{~cm}$ e $145-165 \mathrm{~cm}$.

\subsubsection{Determinações de laboratório}

\subsubsection{Atrazina}

A análise da atrazina na solução do solo foi 
feita no CNPMA da EMBRAPA, utilizando-se o método descrito por RALPH (1990) e modificado por Hermes A.C. (1993)' que basicamente consiste nos seguintes passos:

1) ativação da coluna SEP-PAK VAC contendo resina (seringa de $5 \mathrm{ml}$ contendo resina):

- passam-se através da coluna $5 \mathrm{ml}$ de acetato de etila para análise de resíduo;

- passam-se pela coluna $5 \mathrm{ml}$ de metanol para análise de resíduo;

- passam-se pela coluna $10 \mathrm{ml}$ de água tri-destilada e filtrada.

$$
\text { Nesse processo utilizou-se um conjunto }
$$
apropriado para fazer vácuo nas colunas, constituído por uma bomba de vácuo elétrica acoplada a uma caixa de vidro sobre cuja tampa de plástico rígido são conectadas as colunas. A sucção adotada foi de 3 centibars;

2) Passam-se pela coluna $100 \mathrm{ml}$ da amostra (solução do solo) para concentrar a atrazina;

3) Deixam-se secar as colunas por dez minutos sob vácuo de 0,1 bar;

4) Colocam-se 0,4ml de acetato de etila para eluir o resto de solução;

5) Colocam-se tubos de ensaio sob cada coluna e eluem-se $2,5 \mathrm{ml}$ de metanol;

${ }^{1}$ Ainda não publicado. 
6) Seca-se o eluído com nitrogênio até o volume atingir $1 \mathrm{ml}$;

7) Lê-se em cromatrógrafo de fase líquida.

Os padrões de 0ppm, 0,5ppm, 1ppm, 5ppm e 10ppm foram preparados com solução do solo coletada antes da aplicação da atrazina e receberam o mesmo tratamento das amostras.

A concentração final de atrazina na solução do solo em $\mu \mathrm{g} / \mathrm{l}$ ( $\mathrm{ppb}$ ) para cada profundidade é multiplicada pelo valor do fluxo de água na profundidade e pelo intervalo médio de tempo entre uma coleta e outra para se obter a quantidade Iixiviada por coleta em cada profundidade pela fórmula:

$$
j=10 q C \Delta t
$$

onde: j é a quantidade de atrazina lixiviada em cada período, dada em " $\mu \mathrm{g} / \mathrm{m}^{2}$."; q é o fluxo de água no solo (cm/dia); "C" é a concentração de atrazina na solução do solo ( $\mu g / 1)$; $\Delta t$ é o intervalo de tempo entre uma coleta e outra (dia), e "10" é um fator de conversão para tornar as perdas em " $\mu \mathrm{g} / \mathrm{m}^{2} "$. A perda por lixiviação ao final das cinco coletas será dada por:

$$
Q=\int_{0}^{t_{f}} 10 q C d t=\sum_{1}^{5} 10 q C \Delta t=10 q_{1} C_{1}\left(\Delta t_{1}\right)+\ldots+10 q_{5} C_{5}(\Delta
$$

onde: $Q$ é a quantidade total de atrazina lixiviada na profundidade analisada, no período total do experimento (71 dias) 
3.3.2.2. Cloreto e potássio

o teor de potássio nas amostras foi determinado diretamente no fotômetro de chama do Laboratório de Fertilidade do Solo do CENA e os padrões de 0ppm, 1ppm, 3ppm ,5ppm, $10 \mathrm{ppm}, 15 \mathrm{ppm}$ e $20 \mathrm{ppm}$ foram preparados com cloreto de potássio em água destilada.

Para o cloro adotou-se o sistema de injeçāo em fluxo descrito por ZAGATTO et alii( 1981).

3.3.2.3. Análises químicas e granulométricas

As análises químicas foram: pH em água, pH em $\mathrm{CaCl}_{2} ; \mathrm{H}+\mathrm{Al} ; \mathrm{Ca} ; \mathrm{Mg} ; \mathrm{K}, \mathrm{P}$, e matéria orgânica. As análises foram feitas pelo Laboratório de Fertilidade do Solo do CENA, utilizando as metodologias descritas por RAIJ \& QUAGGIO $(1983)$

Foram determinadas as granulometrias de todas as camadas até a profundidade de $165 \mathrm{~cm}$, no Laboratório de Física do solo do CENA, utilizando o método do densímetro (EMBRAPA， 1979 ).

3.3.2.4. Adsorçāo e dessorção de atrazina

As isotermas de adsorçāo e dessorçāo da atrazina foram obtidas utilizando-se quatro amostras 
compostas constituidas da mistura de terra proveniente das duas parcelas. Na amostra número um foram misturadas as terras coletadas de 0 a $30 \mathrm{~cm}$; na amostra número dois as de 30 a $60 \mathrm{~cm}$; na amostra número três as de 60 a $105 \mathrm{~cm}$ e na amostra número quatro as de 105 a $160 \mathrm{~cm}$ de profundidade.

Foram feitas duas repetiçōes por amostra. As concentraçōes de atrazina em solução foram de: 0ppm; 0,5ppm; 1,0ppm; 5,0ppm e 10,0ppm, enriquecida com atrazina marcada com carbono 14 na proporção de $167 \mathrm{~Bq}(10.000 \mathrm{dpm})$. A solução de zero ppm continha apenas a atrazina marcada, e esta solução serviu de controle, não sendo colocada em contato com o solo.

Para determinação da curva de adsorção, pesouse um grama de solo para cada concentração em tubo de centrifuga com capacidade para 50ml, e adicionou-se $10 \mathrm{ml}$ da solução de atrazina por tubo. Agitou-se por um período de 24 horas e logo após centrifugou-se por 10 minutos a $3.500 \mathrm{rpm}$. Após a centrifugação passou-se $1 \mathrm{ml}$ do sobrenadante para frascos de cintilação e adicionaram-se $10 \mathrm{ml}$ de solução cintiladora. Efetuou-se então a contagem em cintilador. o restante do sobrenadante dos tubos de centrifuga foi descartado e efetuou-se a pesagem dos tubos contendo solo mais o restante da solução.

Para estimar a taxa de dessorção colocaram-se $10 \mathrm{ml}$ de solução de cloreto de cálcio 0,01M em cada tubo e agitou-se por mais 24 horas. Centrifugou-se os tubos por 10 
39 .

minutos a $3.500 \mathrm{rpm}$ e tomou-se $1 \mathrm{ml}$ do sobrenadante em frascos de cintilação. Adicionaram-se $10 \mathrm{ml}$ da solução cintiladora e efetuou-se a leitura. Dos valores obtidos para cada frasco subtrairam-se os valores de contagem devidos ao resto de solução marcada e os valores restantes foram utilizados nos cálculos de dessorção de atrazina.

o ajuste foi feito pela isoterma de adsorção de Freundlich:

$$
\frac{X}{M}=K C^{n}
$$

onde $\mathrm{X} / \mathrm{M}=$ quantidade de adsorvido por unidade de massa do adsorvente; $C$ é a concentração da solução de equilíbrio e $\mathrm{K}$ e $\mathrm{n}$ são constantes obtidas com a linearização do modelo:

$$
\ln \frac{X}{M}=\ln K+n \ln C
$$




\title{
4. RESULTADOS E DISCUSSÃO
}

\begin{abstract}
Os resultados são apresentados na ordem cronológica de sua obtenção e sua discussão é feita em seguida, item por item. A forma de apresentação acompanha os critérios definidos no item 3.3.1.5 de Material e Métodos, para a atrazina, excetuando-se os casos em que a apresentação de dados individuais seja necessária para algum esclarecimento.
\end{abstract}

4.1. Condutividade hidráulica do solo saturado

Os resultados obtidos para condutividade hidráulica saturada, nos nove anéis, em cada parcela, e as médias de cada três anéis na linha, para as quatro épocas, podem ser vistos na Tabela 3 para as parcelas 1 e 2 .

Os dados obtidos mostram uma grande variabilidade dentro de cada parcela entre os nove anéis para cada uma das épocas utilizadas. A variabilidade entre épocas é maior ainda, ou seja, a repetitividade das medidas no tempo é muito baixa.

O coeficiente de variação na parcela 1 oscilou entre 23,4\% (anel número três) e 158\% (anel número um), ambos 
Tabela 3. Condutividade hidráulica do solo saturado (cm/dia) obtidos em quatro épocas, por anel e por linha: época 1 (09/09/92); época 2 (18/09/92); época $3(11 / 12 / 92)$ e época $4(02 / 02 / 93)$. Nas parcelas 1 e 2 .

\begin{tabular}{|c|c|c|c|c|c|c|}
\hline \multirow[b]{2}{*}{ Anel } & \multicolumn{5}{|c|}{ época } & \multirow[b]{2}{*}{$C V(q)$} \\
\hline & 1 & 2 & 3 & 4 & média & \\
\hline & & & parcela & 1 & & \\
\hline 1 & 15.60 & 31.20 & 96.48 & 760.80 & 226.02 & 158.0 \\
\hline 2 & 2.62 & 36.48 & 77.76 & 43.20 & 40.02 & 77.0 \\
\hline 3 & 31.68 & 27.12 & 38.88 & 46.32 & 36.00 & 23.4 \\
\hline Iinha 1 & 16.63 & 31.60 & 71.04 & 283.44 & 100.68 & 208.0 \\
\hline 4 & 14.40 & 72.00 & 150.72 & 390.72 & 156.96 & 105.5 \\
\hline 5 & 8.40 & 4.32 & 92.16 & 36.72 & 35.40 & 114.4 \\
\hline 6 & 19.20 & 84.00 & 61.92 & 280.80 & 111.48 & 104.0 \\
\hline linha 2 & 14.00 & 53.44 & 101.60 & 236.08 & 101.28 & 118.0 \\
\hline 7 & 20.40 & 14.40 & 138.72 & 176.40 & 87.48 & 94.0 \\
\hline 8 & 55.20 & 162.00 & 82.08 & 436.80 & 184.02 & 94.8 \\
\hline 9 & 86.40 & 69.60 & 64.80 & 571.20 & 198.00 & 126.0 \\
\hline Iinha 3 & 54.00 & 82.00 & 95.20 & 394.80 & 156.50 & 110.0 \\
\hline média & 28.21 & 55.68 & 89.28 & 304.80 & 119.49 & 140.8 \\
\hline \multirow[t]{2}{*}{$C V(q)$} & 94.30 & 86.80 & 40.30 & 84.30 & 62.40 & \\
\hline & & & parcela & 2 & & \\
\hline 1 & 386.40 & 950.40 & 96.00 & 31.92 & 366.18 & 114.0 \\
\hline 2 & 62.88 & 152.16 & 97.20 & 196.80 & 127.26 & 46.0 \\
\hline 3 & 130.08 & 172.08 & 158.40 & 73.68 & 133.56 & 32.6 \\
\hline linha 1 & 193.12 & 424.88 & 117.20 & 100.80 & 209.00 & 120.0 \\
\hline 4 & 177.12 & 365.76 & 124.80 & 206.88 & 218.64 & 47.5 \\
\hline 5 & 55.20 & 177.84 & 92.16 & 68.88 & 98.52 & 55.9 \\
\hline 6 & 328.32 & 353.28 & 180.00 & 40.08 & 225.42 & 64.5 \\
\hline linha 2 & 186.88 & 298.96 & 132.32 & 105.28 & 180.86 & 64.0 \\
\hline 7 & 18.24 & 119.76 & 96.48 & 16.08 & 62.64 & 85.0 \\
\hline 8 & 133.92 & 282.96 & 183.60 & 92.88 & 173.34 & 47.0 \\
\hline 9 & 204.72 & 231.84 & 70.56 & 59.28 & 141.60 & 63.0 \\
\hline linha 3 & 118.96 & 211.52 & 116.88 & 56.08 & 125.86 & 67.0 \\
\hline média & 166.32 & 311.8 & 122.13 & 87.4 & 171.9 & 96.2 \\
\hline$C V(q)$ & 74.70 & 81.70 & 34.20 & 78.90 & 52.23 & \\
\hline
\end{tabular}


na linha um. Na parcela 2 os coeficientes de variação foram menores, e variaram entre 32,6 e $114 \%$, também para os anéis três e um, respectivamente.

Quando se analisa as médias obtidas na linha da parcela 1 em comparação com as médias obtidas na linha para a parcela 2, verifica-se que na parcela 1 a condutividade hidráulica cresceu com o tempo, e na parcela 2 a condutividade hidráulica diminuiu ao longo do tempo.

A média geral da parcela 1 para as quatro épocas foi de 119,5 cm/dia e para a parcela 2 foi de 172 cm/dia, isto é, ao fim das quatro épocas, a parcela 2 apresentou O valor de KO 1,44 vezes maior que O Ko da parcela 1. Mas, ao analisar-se época por época, os dados da Tabela 3 indicam que na época um o Ko médio da parcela 2 foi seis vezes maior que o Ko médio da parcela 1; na segunda época o Ko da parcela 2 foi 5,6 vezes maior que o Ko da parcela 1 ; na terceira época a diferença caiu para 1,37 vezes, e na quarta época já houve uma inversão de valores. O Ko da parcela 1 foi 3,49 vezes maior que o Ko da parcela 2 .

Esta grande variação de Ko no tempo e dentro de cada época analisada indica o quanto é difícil extrapolar e usar em modelos analíticos dados de condutividade hidráulica do solo saturado gerados neste tipo de solo.

o solo, sendo um complexo corpo poroso, apresenta grande variação na forma, continuidade, número, diâmetro, distribuição espacial e estabilidade de poros, 
exibindo um comportamento que muda com o tempo e com o cultivo. No caso presente, as superficies das parcelas foram mantidas completamente descobertas durante as quatro épocas e o que normalmente deveria acontecer era que os agregados expostos ao impacto direto de gotas de chuva poderiam ser destruídos com conseqüente formação de selo ou crosta de baixa condutividade hidráulica na superfície. Isto, certamente, é causa de diminuição do ko com o passar do tempo, porém não explica porque na parcela 1 o ko aumentou ao longo do tempo ao invés de diminuir. Como o solo utilizado tem caracteristicas expansivas apresentando fendas profundas ao secarem, o umedecimento e secamento alternados devem mudar - arranjo do corpo poroso e tornar pouco previsivel o comportamento de Ko. Esta é, provavelmente, a causa principal da grande variabilidade e instabilidade do Ko ao longo do tempo

A presença destas fendas foi registrada na área experimental. Após jogar uma suspensão de cal sobre a superficie, abriu-se uma trincheira no dia seguinte e a coloração branca dentro das fendas foi constatada até a profundidade de um metro (Apêndice 1). 
44 .

4.2. Condutividade hidráulica do solo não saturado

Os valores da umidade de saturação $\left(\theta_{0}\right)$ são apresentados na Tabela 4 para as parcelas 1 e 2, incluindo também os valores médios obtidos para cada três tubos na Iinha.

Tabela 4. Valores de umidade volumétrica de saturação $\left(\theta_{0}\right)$ nas parcelas 1 e 2 e valores médios nas linhas.

\begin{tabular}{|c|c|c|c|c|c|c|c|c|}
\hline \multirow{2}{*}{\multicolumn{2}{|c|}{ tubo }} & \multicolumn{4}{|c|}{ profundidade $(\mathrm{cm})$} & \multirow[b]{2}{*}{ media } & \multirow[b]{2}{*}{ d.padrao } & \multirow[b]{2}{*}{$c v(z)$} \\
\hline & & 20 & 50 & 100 & 150 & & & \\
\hline \multicolumn{9}{|c|}{ parcela 1} \\
\hline 1 & & 0.4067 & 0.4282 & 0.4167 & 0.4228 & 0.4186 & 0.0080 & 1.9079 \\
\hline 2 & & 0.4098 & 0.4221 & 0.4221 & 0.4297 & 0.4209 & 0.0071 & 1.6986 \\
\hline 3 & & 0.4029 & 0.4244 & 0.4090 & 0.4052 & 0.4104 & 0.0084 & 2.0423 \\
\hline linha & 1 & 0.4065 & 0.4249 & 0.4159 & 0.4192 & 0.4166 & 0.0091 & 2.1768 \\
\hline 4 & & 0.4067 & 0.4305 & 0.4144 & 0.4213 & 0.4182 & 0.0088 & 2.0968 \\
\hline 5 & & 0.4205 & 0.4374 & 0.4144 & 0.4098 & 0.4205 & 0.0105 & 2.4895 \\
\hline 6 & & 0.4167 & 0.4328 & 0.4159 & 0.4259 & 0.4228 & 0.0070 & 1.6490 \\
\hline linha & 2 & 0.4146 & 0.4336 & 0.4149 & 0.4190 & 0.4205 & 0.0091 & 2.1521 \\
\hline 7 & & 0.3990 & 0.4343 & 0.4113 & 0.4113 & 0.4140 & 0.0128 & 3.0846 \\
\hline 8 & & 0.4144 & 0.4428 & 0.4129 & 0.4067 & 0.4192 & 0.0139 & 3.3226 \\
\hline 9 & & 0.4205 & 0.4474 & 0.4297 & 0.4374 & 0.4338 & 0.0099 & 2.2779 \\
\hline linha: & 3 & 0.4113 & 0.4415 & 0.4180 & 0.4185 & 0.4223 & 0.0149 & 3.5248 \\
\hline \multicolumn{9}{|c|}{ parcela 2} \\
\hline 1 & & 0.3944 & 0.4305 & 0.4159 & 0.4251 & 0.4165 & 0.0138 & 3.3057 \\
\hline 2 & & 0.4067 & 0.4343 & 0.4213 & 0.4082 & 0.4176 & 0.0112 & 2.6773 \\
\hline 3 & & 0.4075 & 0.4290 & 0.4144 & 0.4221 & 0.4182 & 0.0081 & 1.9294 \\
\hline linha & 1 & 0.4029 & 0.4313 & 0.4172 & 0.4185 & 0.4175 & 0.0113 & 2.7004 \\
\hline 4 & & 0.4190 & 0.4098 & 0.4267 & 0.4221 & 0.4194 & 0.0062 & 1.4729 \\
\hline 5 & & 0.3944 & 0.4221 & 0.4144 & 0.4244 & 0.4138 & 0.0118 & 2.8479 \\
\hline 6 & & 0.4113 & 0.4213 & 0.4190 & 0.4251 & 0.4192 & 0.0050 & 1.2035 \\
\hline linha & 2 & 0.4082 & 0.4177 & 0.4200 & 0.4239 & 0.4175 & 0.0086 & 2.0627 \\
\hline 7 & & 0.4059 & 0.4297 & 0.4236 & 0.4175 & 0.4192 & 0.0088 & 2.0975 \\
\hline 8 & & 0.3975 & 0.3990 & 0.4136 & 0.4159 & 0.4065 & 0.0083 & 2.0442 \\
\hline 9 & & 0.3937 & 0.4136 & 0.4159 & 0.4190 & 0.4105 & 0.0099 & 2.4199 \\
\hline I inha & 3 & 0.3990. & 0.4141 & 0.4177 & 0.4175 & 0.4121 & 0.0105 & 2.5405 \\
\hline
\end{tabular}


Os valores de "a", do coeficiente linear $\left(\frac{1}{\gamma}\right.$ In $\left.\left(\frac{\gamma K_{0}}{a z}\right)\right)$ da equação (3), de gama e da condutividade hidráulica saturada estimada pela equação (5), são apresentados na Tabela 5 para a parcela 1 e na Tabela 6 para a parcela 2. Os valores destes parâmetros calculados em média para cada três tubos de acesso para sonda na linha também são mostrados nas mesmas tabelas.

Nas Figuras 6A e 6B podem ser observados os perfis de umidade para os seis primeiros dias do período de determinação da condutividade hidráulica do solo não saturado $(K(\theta))$ respectivamente para as parcelas 1 e 2 .

Como pode ser visto na Tabela 4, houve baixa variação entre os valores medidos, tanto para a parcela 1 como para a parcela 2. O maior coeficiente de variação encontrado foi de apenas $3,52 \%$ na linha três da parcela 1 e o menor foi de $1,2 \%$ encontrado no tubo seis da parcela 2.

Pode ser observado também nesta Tabela que os valores de $\theta_{0}$ na profundidade de $50 \mathrm{~cm}$ foram um pouco mais elevados, tanto na parcela 1 como na parcela 2, indicando uma leve influência do horizonte B textural sobre este parâmetro. Os parâmetros gama, "a" e condutividade hidráulica do solo saturado estimada pelo modelo apresentaram grande variação dentro de cada parcela e entre parcelas (Tabelas 5 e 6). 
Tabela 5. Valores dos coeficientes gama, "a", coeficiente linear da equação (3) e condutividade hidráulica do solo saturado estimada pelo método de Libardi. Valores individuais e médios na linha, parcela 1.

\begin{tabular}{|c|c|c|c|c|}
\hline \multirow[b]{2}{*}{ tubo } & \multicolumn{4}{|c|}{ valores de gama } \\
\hline & $20 \mathrm{~cm}$ & $50 \mathrm{~cm}$ & $100 \mathrm{~cm}$ & $150 \mathrm{~cm}$ \\
\hline 1 & 112.55 & 141.56 & 34.137 & 19.75 \\
\hline 2 & 100.01 & 150.83 & 137.16 & 86.588 \\
\hline 3 & 608.64 & 222.17 & 104.59 & 80.25 \\
\hline 4 & 92.2 & 161.86 & 95.997 & 74.014 \\
\hline 5 & 222.17 & 144.57 & 71.352 & 82.679 \\
\hline 6 & 103.85 & 129.84 & 72.187 & 67.272 \\
\hline 7 & 109.42 & 97.771 & 74.499 & 81.241 \\
\hline 8 & 150.74 & 95.593 & 62.321 & 100.65 \\
\hline 9 & 108.71 & 190.69 & 80.665 & 65.024 \\
\hline Iinha & \multicolumn{3}{|c|}{ média de gama na } & linha \\
\hline 1 & 161.11 & 233.92 & 65.011 & 40.191 \\
\hline 2 & 120.12 & 144.26 & 78.358 & 74.123 \\
\hline \multirow[t]{2}{*}{3} & 120.13 & 115.69 & 71.654 & 79.738 \\
\hline & \multicolumn{3}{|c|}{ valores de "a" } & \\
\hline tubo & $20 \mathrm{~cm}$ & $50 \mathrm{~cm}$ & $100 \mathrm{~cm}$ & $150 \mathrm{~cm}$ \\
\hline 1 & 1.00 & 1.1288 & 0.5148 & 0.4734 \\
\hline 2 & 1.00 & 1.2541 & 1.0937 & 0.7678 \\
\hline 3 & 1.00 & 2.0833 & 0.2938 & 0.4191 \\
\hline 4 & 1.00 & 1.3778 & 0.8781 & 0.7578 \\
\hline 5 & 1.00 & 0.8254 & 0.6049 & 0.7757 \\
\hline 6 & 1.00 & 1.1252 & 0.7468 & 0.7744 \\
\hline 7 & 1.00 & 0.9468 & 0.8143 & 0.916 \\
\hline 8 & 1.00 & 0.8171 & 0.6885 & 1.0839 \\
\hline 9 & 1.00 & 1.377 & 0.7217 & 0.6863 \\
\hline Iinha & & média & na linl & \\
\hline 1 & 1.00 & 1.226 & 0.5605 & 0.5099 \\
\hline 2 & 1.00 & 1.1005 & 0.7319 & 0.7693 \\
\hline 3 & 1.00 & 0.9815 & 0.7386 & 0.8664 \\
\hline
\end{tabular}

\begin{tabular}{|c|c|c|c|c|}
\hline \multirow[b]{2}{*}{ tubo } & \multicolumn{4}{|c|}{ coeficiente linear } \\
\hline & $20 \mathrm{~cm}$ & $50 \mathrm{~cm}$ & $100 \mathrm{~cm}$ & $150 \mathrm{~cm}$ \\
\hline 1 & 0.0245 & 0.0077 & 0.0159 & 0.016 \\
\hline 2 & 0.0322 & 0.013 & 0.0211 & 0.0696 \\
\hline 3 & 0.0244 & 0.0143 & 0.015 & 0.0553 \\
\hline 4 & 0.0257 & 0.0071 & 0.0384 & 0.0623 \\
\hline 5 & 0.0323 & 0.0124 & 0.0357 & 0.0418 \\
\hline 6 & 0.0253 & 0.0079 & 0.02 & 0.0624 \\
\hline 7 & 0.02 & 0.0116 & 0.0443 & 0.0601 \\
\hline 8 & 0.0418 & 0.0078 & 0.0307 & 0.0507 \\
\hline 9 & 0.0368 & 0.0203 & 0.0642 & 0.0929 \\
\hline \multicolumn{2}{|c|}{ Iinha } & \multicolumn{3}{|c|}{ média na linha } \\
\hline 1 & 0.0274 & 0.0126 & 0.0173 & 0.047 \\
\hline 2 & 0.0278 & 0.0091 & 0.0314 & 0.0555 \\
\hline \multirow[t]{2}{*}{3} & 0.0329 & 0.0132 & 0.0464 & 0.0679 \\
\hline & \multicolumn{4}{|c|}{ valores de Ko (cm/dia) } \\
\hline tubo & $20 \mathrm{~cm}$ & $50 \mathrm{~cm}$ & $100 \mathrm{~cm}$ & $150 \mathrm{~cm}$ \\
\hline 1 & 2.788 & 1.178 & 2.591 & 4.935 \\
\hline 2 & 5.029 & 2.945 & 14.401 & 550.27 \\
\hline 3 & $9 \times 10^{4}$ & 11.189 & 1.354 & 66.060 \\
\hline 4 & 2.324 & 1.352 & 36.556 & 154.19 \\
\hline 5 & 118.92 & 1.703 & 10.855 & 44.688 \\
\hline 6 & 2.662 & 1.207 & 4.389 & 114.64 \\
\hline 7 & 1.638 & 1.504 & 29.654 & 222.46 \\
\hline 8 & 72.350 & 0.899 & 7.489 & 266.36 \\
\hline 9 & 10.048 & 17.167 & 159.19 & 664.96 \\
\hline \multicolumn{2}{|l|}{ Iinha } & \multicolumn{3}{|c|}{ média na linha } \\
\hline 1 & 10.175 & 4.951 & 2.660 & 12.563 \\
\hline 2 & 4.687 & 1.424 & 10.930 & 95.157 \\
\hline 3 & 8.648 & 1.955 & 28.680 & 365.78 \\
\hline
\end{tabular}


Tabela 6. Valores dos coeficientes gama, "a", coeficiente linear da equação (3) e condutividade hidráulica do solo saturado estimada pelo método de Libardi. valores individuais e médios, parcela 2.

\begin{tabular}{rrrrr}
\hline & \multicolumn{5}{c}{ valores de gama } \\
\cline { 2 - 5 } tubo & $20 \mathrm{~cm}$ & $50 \mathrm{~cm}$ & $100 \mathrm{~cm}$ & $150 \mathrm{~cm}$ \\
\hline 1 & 169.35 & 117.23 & 159.77 & 91.483 \\
2 & 161.84 & 64.362 & 119.25 & 117.08 \\
3 & 319.69 & 793.65 & 137.78 & 75.517 \\
4 & 285.96 & 261.92 & 132.08 & 153.4 \\
5 & 246.73 & 176.93 & 106.94 & 81.374 \\
6 & 179.89 & 139.45 & 92.704 & 88.067 \\
7 & 163.08 & 176.77 & 103.72 & 99.493 \\
8 & 139.76 & 217.34 & 161.45 & 117.08 \\
9 & 156.62 & 160.67 & 93.677 & 87.458
\end{tabular}

\begin{tabular}{rrrrrr}
\hline Iinha & \multicolumn{4}{c}{ média na linha } \\
\hline 1 & 203.62 & 119.02 & 136.57 & 126.14 \\
2 & 205.09 & 196.12 & 108.27 & 99.463 \\
3 & 205.8 & 224.72 & 113.16 & 105.71
\end{tabular}

\begin{tabular}{c} 
valores de "a" \\
\cline { 2 - 3 } tubo $20 \mathrm{~cm} \quad 50 \mathrm{~cm} \quad 100 \mathrm{~cm} \quad 150 \mathrm{~cm}$
\end{tabular}

\begin{tabular}{rrrrr}
\hline 1 & 1 & 0.6907 & 0.9609 & 0.7265 \\
2 & 1 & 0.6988 & 1.159 & 0.6894 \\
3 & 1 & 1.354 & 0.4299 & 0.3703 \\
4 & 1 & 0.924 & 0.6376 & 0.6144 \\
5 & 1 & 0.5407 & 0.5512 & 0.6592 \\
6 & 1 & 0.7519 & 0.6665 & 0.6225 \\
7 & 1 & 0.8658 & 0.8196 & 0.6292 \\
8 & 1 & 0.9139 & 0.8474 & 1.2843 \\
9 & 1 & 1.0967 & 0.7724 & 1.0992 \\
\hline
\end{tabular}

\begin{tabular}{clllr}
\hline Iinha & \multicolumn{3}{l}{ média na linha } \\
\hline 1 & 1 & 1.0387 & 0.8205 & 0.787 \\
2 & 1 & 0.7782 & 0.6197 & 0.6357 \\
3 & 1 & 1.3047 & 0.7369 & 1.0079
\end{tabular}

\begin{tabular}{|c|c|c|c|c|}
\hline \multirow[b]{2}{*}{ tubo } & \multicolumn{3}{|c|}{ valores do } & \multirow{2}{*}{$\begin{array}{l}\text { Iinear } \\
150 \mathrm{~cm}\end{array}$} \\
\hline & $20 \mathrm{~cm}$ & $50 \mathrm{~cm}$ & $100 \mathrm{~cm}$ & \\
\hline 1 & 0.0272 & 0.0245 & 0.04 & 0.0654 \\
\hline 2 & 0.0309 & 0.014 & 0.0477 & 0.0519 \\
\hline 3 & 0.02 & 0.023 & 0.0599 & 0.0743 \\
\hline 4 & 0.0705 & 0.0226 & 0.0335 & 0.0672 \\
\hline 5 & 0.0249 & 0.0197 & 0.0437 & 0.0488 \\
\hline 6 & 0.0357 & 0.0127 & 0.0439 & 0.0638 \\
\hline 7 & 0.0321 & 0.0295 & 0.0419 & 0.0573 \\
\hline 8 & 0.0365 & 0.0128 & 0.0202 & 0.0566 \\
\hline 9 & 0.0344 & 0.018 & 0.041 & 0.0615 \\
\hline \multicolumn{2}{|c|}{ Iinha } & \multicolumn{3}{|c|}{ média na linha } \\
\hline 1 & 0.0296 & 0.021 & 0.0438 & 0.0597 \\
\hline 2 & 0.0434 & 0.0187 & 0.0404 & 0.0599 \\
\hline \multirow[t]{2}{*}{3} & 0.0345 & 0.0207 & 0.0344 & 0.0589 \\
\hline & \multicolumn{4}{|c|}{ valores de Ko (cm/dia) } \\
\hline tubo & $20 \mathrm{~cm}$ & $50 \mathrm{~cm}$ & $100 \mathrm{~cm}$ & $150 \mathrm{~cm}$ \\
\hline 1 & 11.845 & 5.1995 & 358.63 & 471.96 \\
\hline 2 & 18.484 & 1.3364 & 285.65 & 382.46 \\
\hline 3 & 37.099 & $7 \times 10^{6}$ & 1200.2 & 200.78 \\
\hline 4 & $4 \times 10^{7}$ & 66.115 & 40.425 & 17964 \\
\hline 5 & 37.77 & 5.0252 & 55.144 & 64.398 \\
\hline 6 & 67.925 & 1.5846 & 42.282 & 292.68 \\
\hline 7 & 23.155 & 45.023 & 61.139 & 283.09 \\
\hline 8 & 23.526 & 3.3686 & 13.686 & 1246.6 \\
\hline 9 & 27.948 & 6.1734 & 38.432 & 408.56 \\
\hline Iinha & & média $n$ & na linha & \\
\hline 1 & 40.713 & 5.3393 & 239.03 & 1734.6 \\
\hline 2 & 721.73 & 3.0802 & 9.0761 & 49.594 \\
\hline 3 & 118.27 & 12.277 & 6.3716 & 96.31 \\
\hline
\end{tabular}




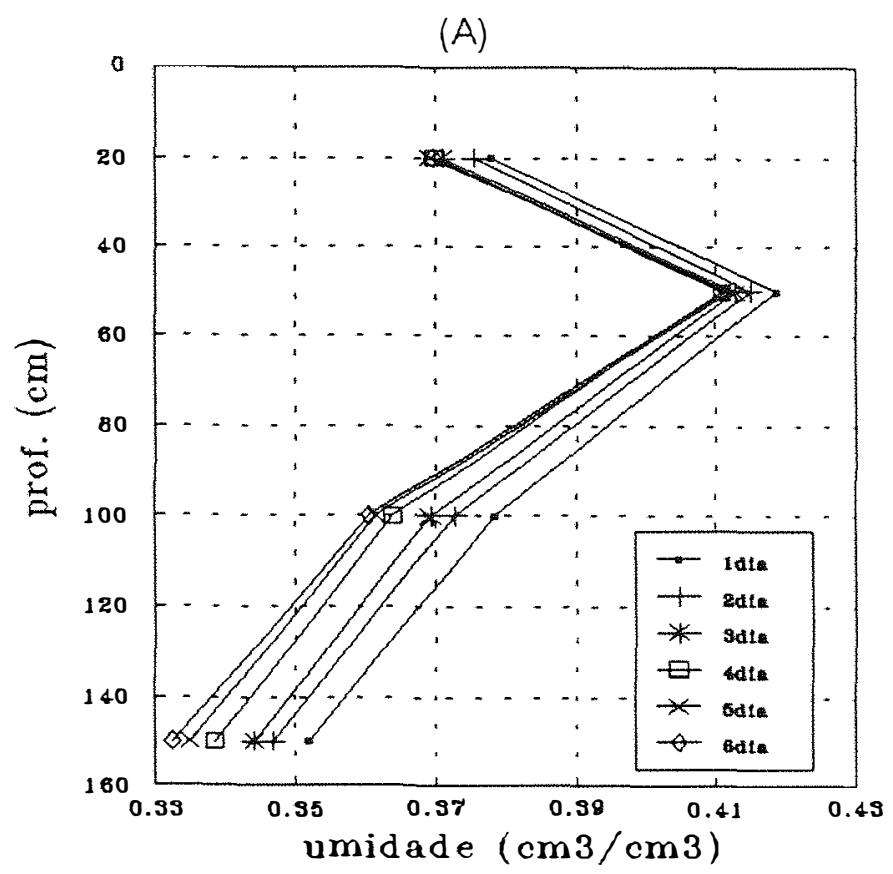

(B)

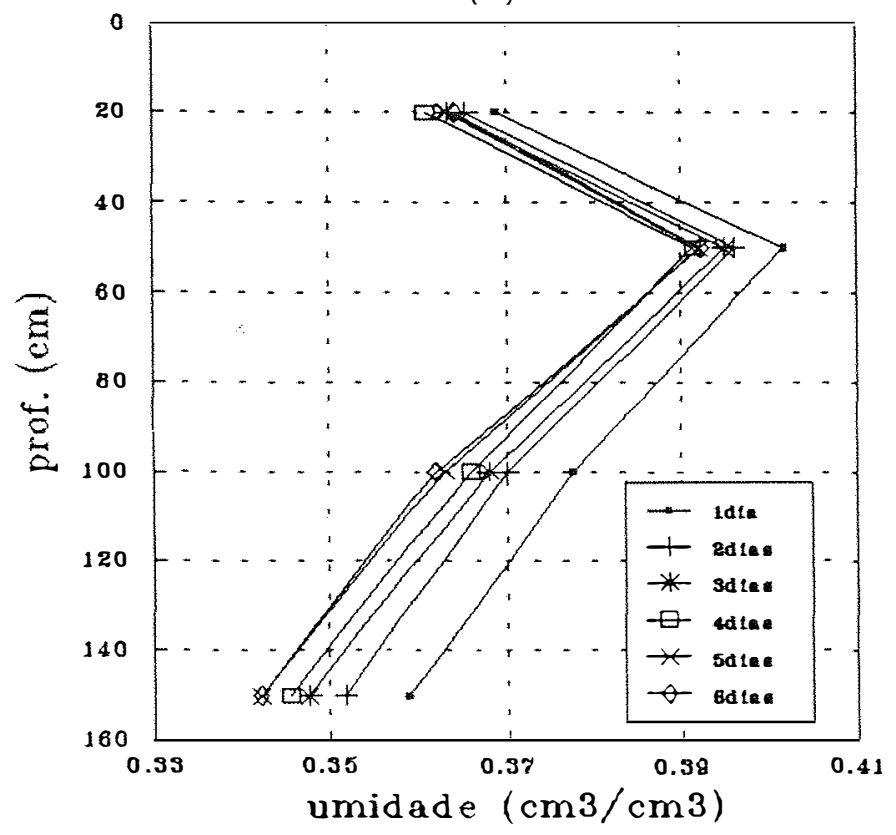

Figura 6. Variação da umidade durante determinação da condutividade hidráulica pelo método de Libardi. (A) parcela 1 e (B) parcela 2 . 
Os valores de gama da parcela 1 (Tabela 5) foram em média menores que os valores de gama da parcela 2 (Tabela 6). Os valores de "a" também foram muito variáveis nas duas parcelas. Como gama e "a" são utilizados no cálculo da condutividade hidráulica do solo saturado (Ko), a grande variabilidade destes parâmetros se reflete em variabilidade, nos valores de Ko, O que pode ser visto na Tabela 5 para a parcela 1 e na Tabela 6 para a parcela 2. Se dividirmos 0 maior valor de Ko da parcela 1 pelo menor valor da mesma camada vamos encontrar um fator de 54.945 vezes. Este mesmo procedimento feito para a parcela 2 nos fornece um fator de 3.376 .952 vezes. Quando foram efetuados os cálculos para obtenção de Ko médio na linha, descartaram-se estes valores muito extremos.

o aparecimento destes valores altos está, como pode ser visto nas Tabelas 5 e 6 , relacionado com valores extremos de gama, ou valores altos do coeficiente linear. Pela figura 6 observa-se que tanto na parcela 1 (Figura 6A) como na parcela 2 (Figura 6B) houve uma diminuição na velocidade de drenagem a partir do terceiro dia, principalmente na camada de 20 a $50 \mathrm{~cm}$ de profundidade. Nesta camada os valores de $\theta$ se mantiveram sempre mais elevados, fazendo com que o perfil de umidade ficasse deslocado para o lado direito. Este comportamento da curva nesta profundidade coincide com o horizonte B textural que conforme pode ser visto na Tabela 2 para as parcelas 1 e 2, apresenta um teor 
de argila mais elevado. A pequena variação de umidade nesta camada superior do perfil dificultou o ajuste do modelo para alguns dos nove tubos de cada parcela.

o ensaio para determinação da condutividade hidráulica teve duração de oito dias. Mas, apesar de todos os cuidados tomados, houve infiltração lateral em alguns pontos a partir do quinto dia, chegando inclusive a prejudicar a drenagem próximo a alguns tubos de acesso para a sonda de nêtrons. Nos pontos onde houve esta contaminação, o ajuste foi feito até o quarto dia (Apêndice 2).

Comparando os valores de Ko da Tabela 3 com os valores de Ko calculados (Tabelas 5 e 6) a $20 \mathrm{~cm}$ de profundidade, verifica-se que praticamente os valores calculados não reproduziram os valores medidos na superfície. Isto é esperado, pois o ko calculado é obtido em cada profundidade e $O$ Ko medido na superfície vai refletir o comportamento da camada de menor porosidade, que governa o fluxo saturado, independentemente da profundidade que ela esteja, podendo ou não coincidir com a profundidade onde estão sendo calculados os Ko do modelo.

Apesar da grande variação observada, os Ko médios para cada linha dentro de cada parcela, bem como os gamas médios em cada linha, foram utilizados para estimar os valores da condutividade hidráulica do solo não saturado, que foram utilizados para estimar o fluxo de água no solo pela equação de Darcy, durante o período de coleta de atrazina. 
Logicamente, estes dados apresentam apenas uma primeira aproximação desses fluxos, uma vez que sua variabilidade praticamente proíbe seu uso.

\subsection{Lixiviação da Atrazina}

Para facilitar a discussão do movimento da atrazina no solo, são apresentados também neste item os resultados obtidos para potencial total e perfis de umidade no período de coleta de solução do solo para determinação da atrazina.

Na Figura 7 ( $A, B$ e C) podem ser observadas as variações do potencial total médio de água no solo da parcela 1 onde, na legenda interna, b1, b2 e b3 ( $b$ de bateria) referem-se, respectivamente, à média dos valores de potencial total obtidos pelos três conjuntos de tensiômetros das linhas 1, 2 e 3. co indica a coleta utilizada como testemunha, c1 a C5 as coletas de atrazina durante o experimento.

Os perfis de umidade média para cada linha na parcela 1 são mostrados na Figura 8, sendo que a Figura $8 \mathrm{~A}$ mostra os perfis de umidade da bateria 1 formada pelos tubos um, dois e três (Iinha 1); a Figura 8B mostra os perfis de umidade da bateria 2 formada pelos tubos quatro, cinco e seis (linha do meio), e a Figura 8 C mostra os perfis de umidade da bateria 3 formada pelos tubos sete, oito, e nove (linha 3). Os resultados obtidos nas análises de solução 
(A)

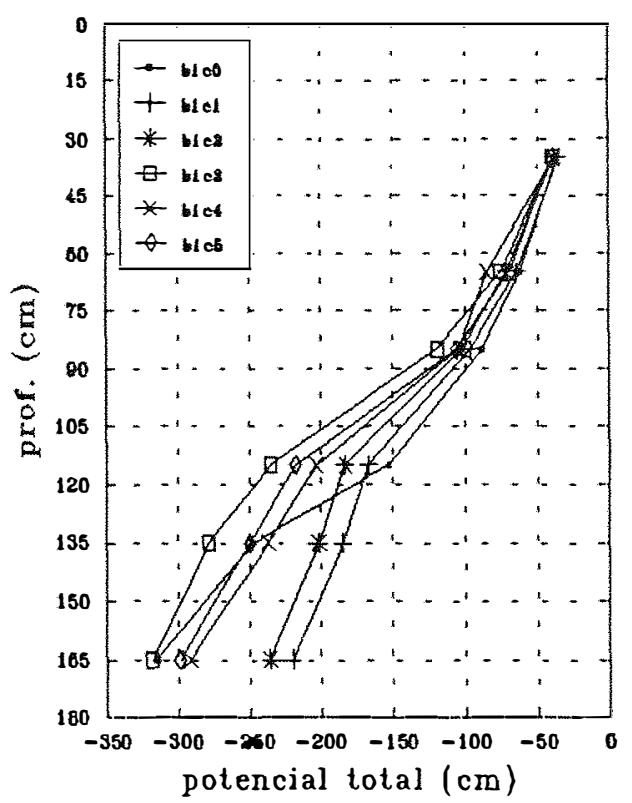

(B)

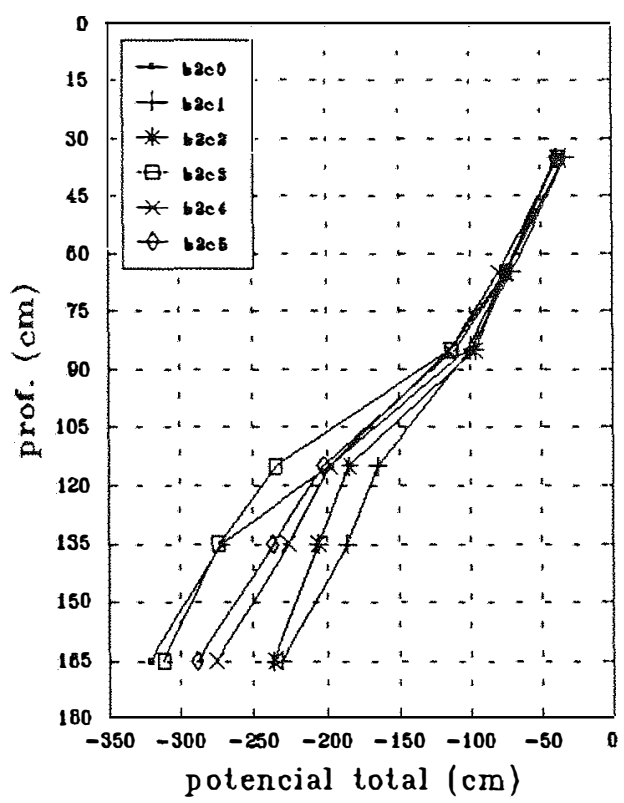

(C)

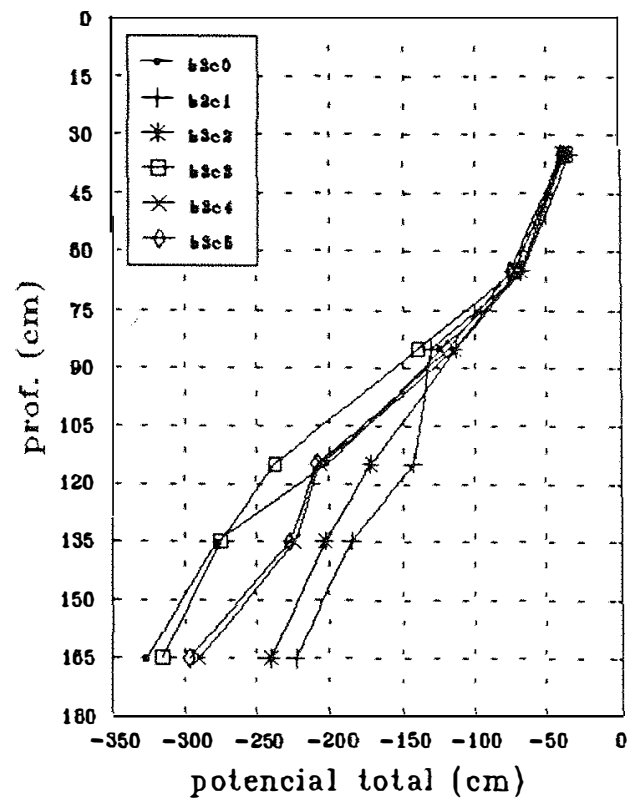

Figura 7. Potencial total de água no solo na parcela 1 medido nos dias de coleta. (A) média da linha $1 ;$ (B) média da linha 2 , e (C) média da linha 3. Legenda: b1, b2 e b3 = linhas; c0 = coleta da testemunha, e cl a c5: coletas de solução contendo atrazina. 
(A)

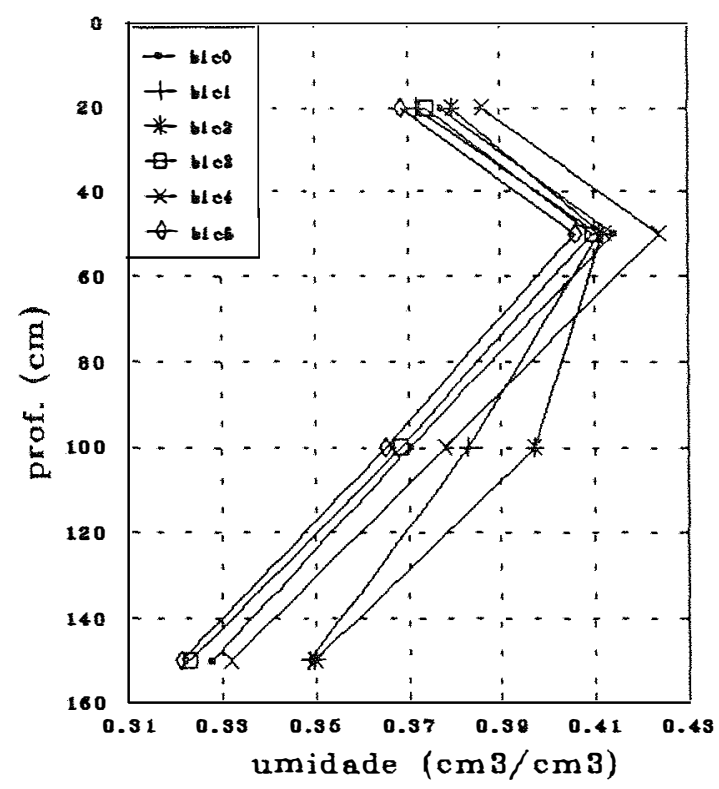

(B)

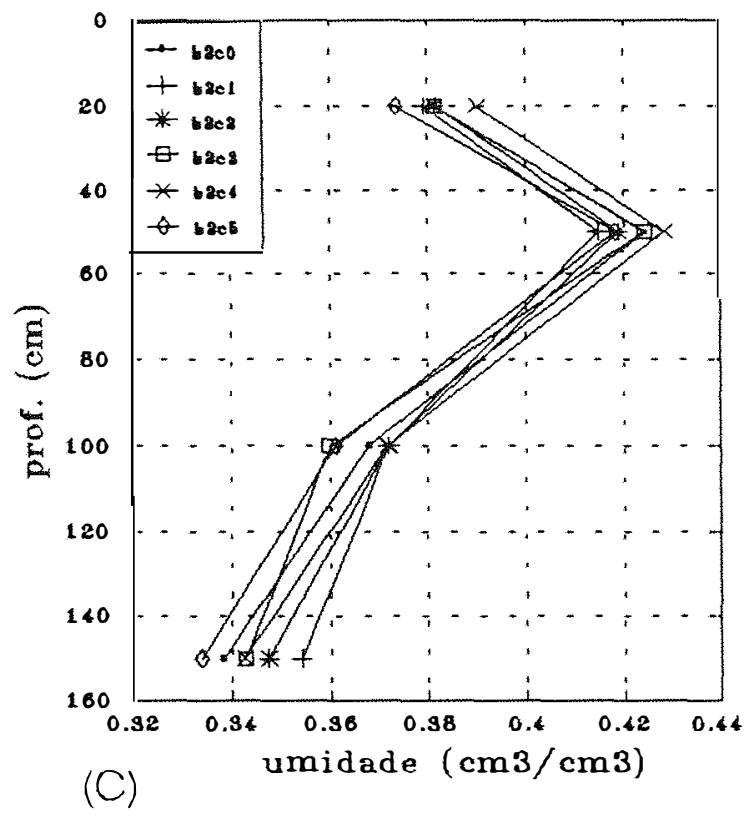

(C)

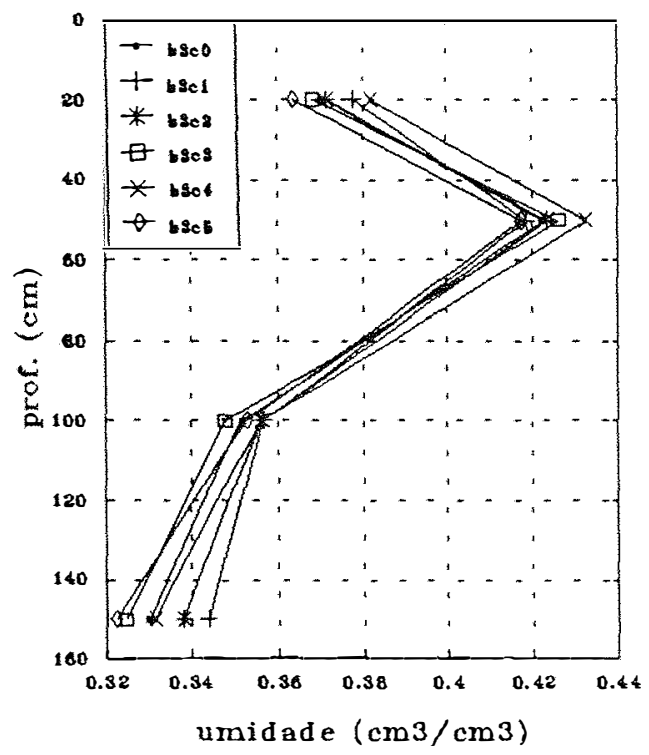

Figura 8. Perfis de umidade média nos dias de coleta da atrazina na parcela 1. (A) média da linha 1 ; (B) média da linha 2 ; (C) média da linha 3 . Legenda: b1, b2, b3 = linhas; $c 0=d i a$ de coleta da testemunha e cl a $c 5$ = dias de coleta de solução contendo atrazina. 
do solo para atrazina estão apresentados na forma de gráficos para possibilitar uma melhor compreensão e melhor visualização das variações de concentração no perfil com o tempo. Os dados numéricos encontram-se no Apêndice 3. As Figuras 9A, 9B, $9 \mathrm{C}$ e $9 \mathrm{D}$ mostram os teores de atrazina na solução do solo nas cinco coletas efetuadas, respectivamente para linhas 1,2 e 3 e média geral da parcela 1.

Analogamente ao que foi apresentado para a parcela 1, são mostrados na Figura 10 os potenciais totais de água no solo por linha na parcela 2 .

Na Figura $11 \mathrm{~A}$ são apresentados os perfis de umidade para a linha 1 da parcela 2; na Figura 11B os perfis para a linha 2 e na Figura $11 \mathrm{C}$ os perfis para a linha 3.

As concentrações de atrazina na solução do solo da parcela 2 são apresentadas graficamente por linha na Figura 12 sendo que a concentração média por profundidade e por coleta em toda a parcela 2 pode ser vista na Figura 12D. Os dados de perdas de atraina por lixiviação por período nas duas parcelas são apresentados na Tabela 7 . Durante o período de avaliação da atrazina no solo, procurou-se manter elevado o teor de água do solo, para que 0 excesso de água oriunda das precipitaçōes pluviométricas e irrigações drenassem com facilidade por ação do potencial gravitacional, e evitasse o processo de ascensão capilar, que poderia fazer com que a atrazina diluída na solução do solo migrasse de baixo para cima no perfil. Na 
(A)

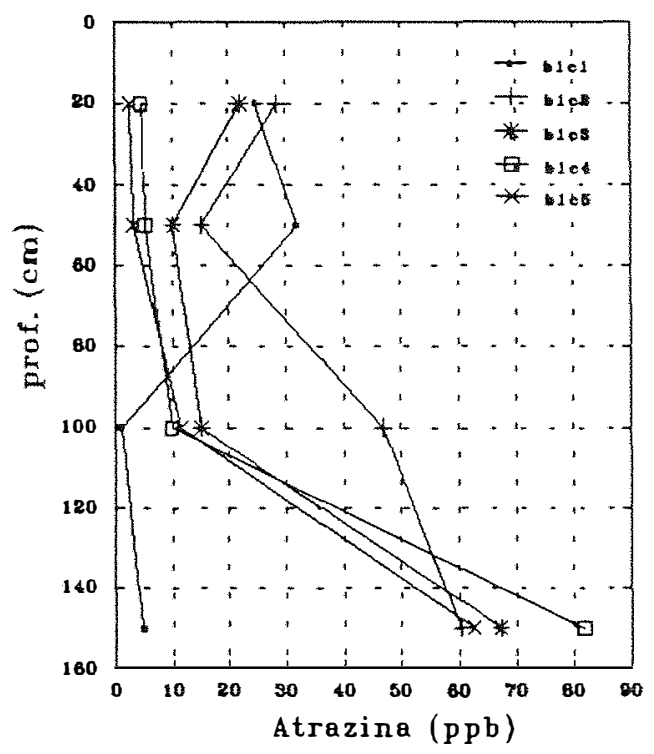

(C)

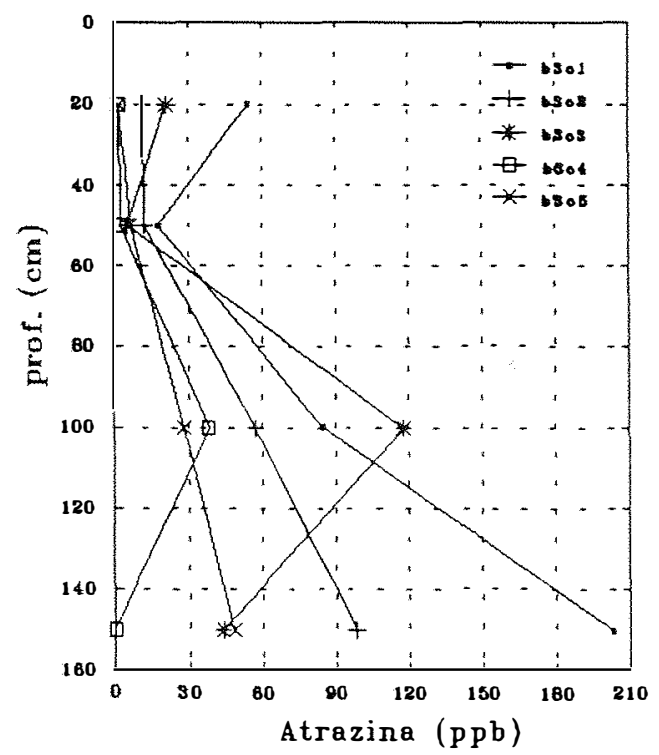

(B)

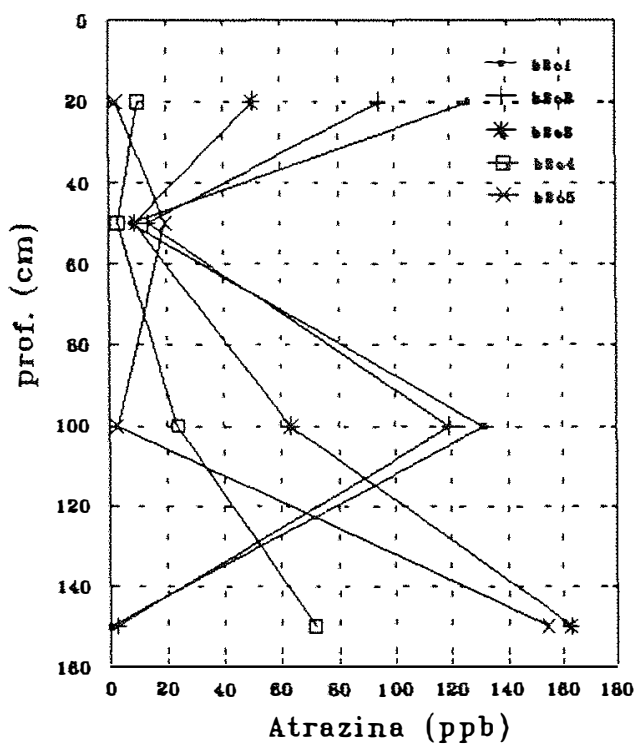

(D)

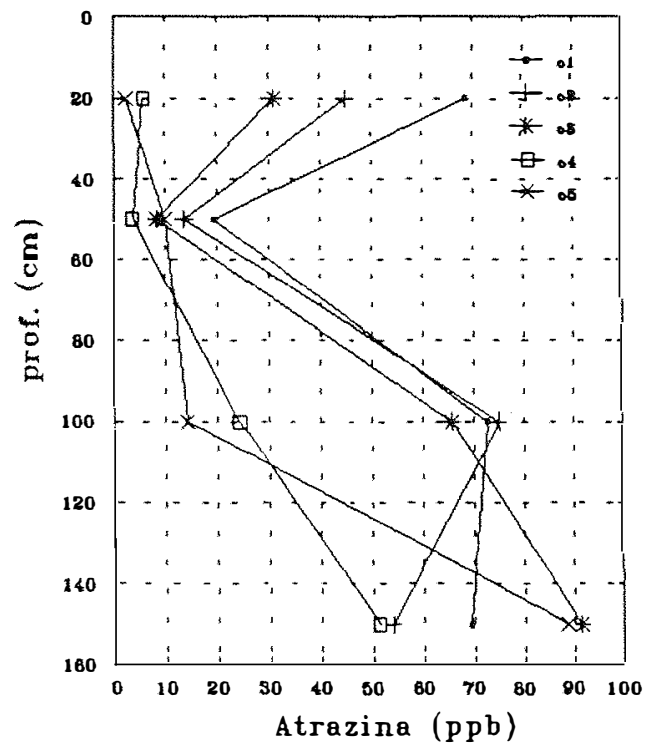

Figura 9. Concentração de atrazina por linha (A, B, C) e concentração média da parcela 1 (D). (A): linha 1 ; (B): linha $2 ;(C)$ : linha 3 . Legenda: b1, b2 e b3: linhas; cl a c5: coletas. 
(A)

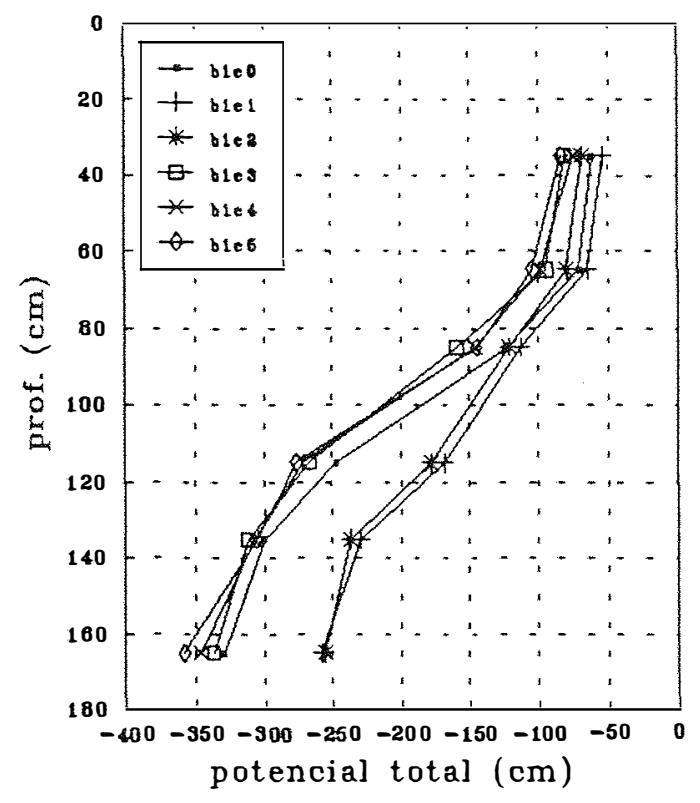

(B)

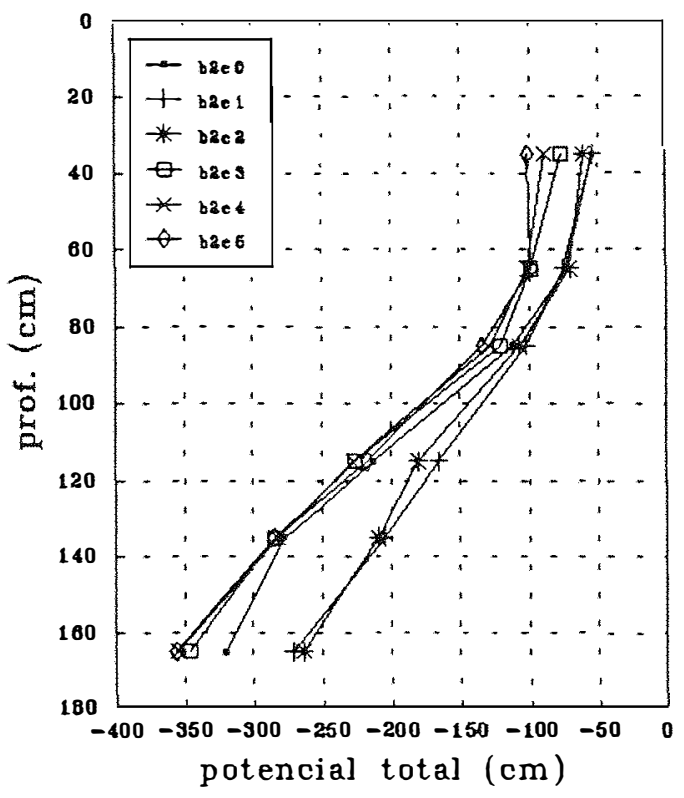

(C)

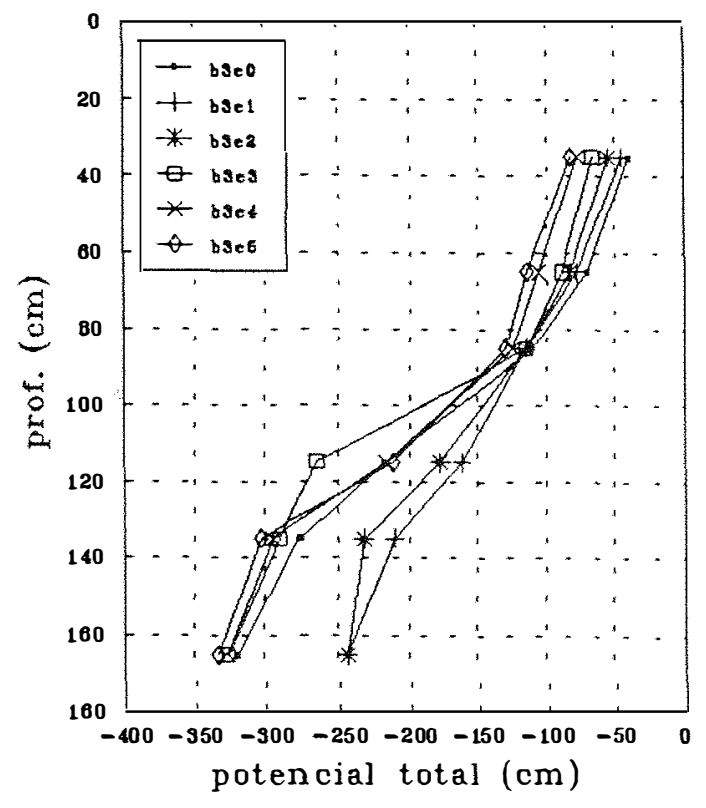

Figura 10. Potencial total de água no solo na parcela 2 medido nos dias de coleta. (A): média da linha $1 ;$ (B): média da linha 2; ( $C$ ): média da linha 3 . Legenda: b1, b2 e b3: linhas; $c 0=$ coleta da testemunha e cl a c5: coletas de solução contendo atrazina. 
(A)

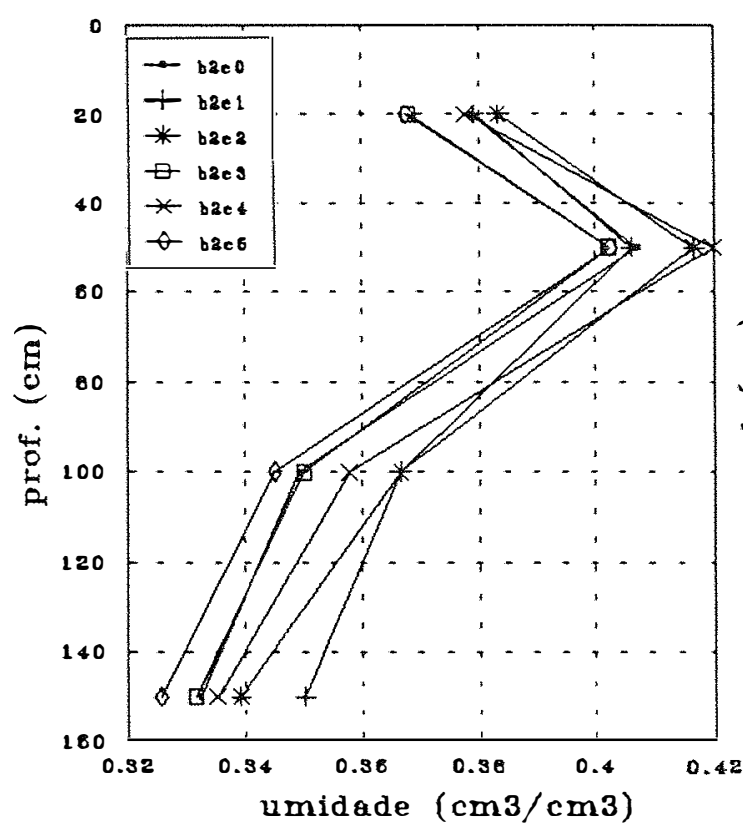

(B)

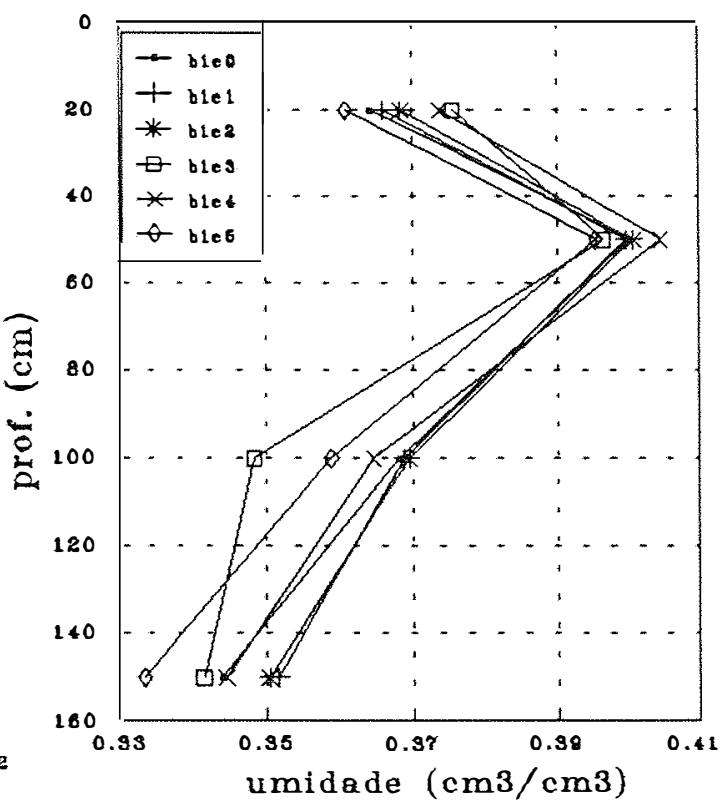

(C)

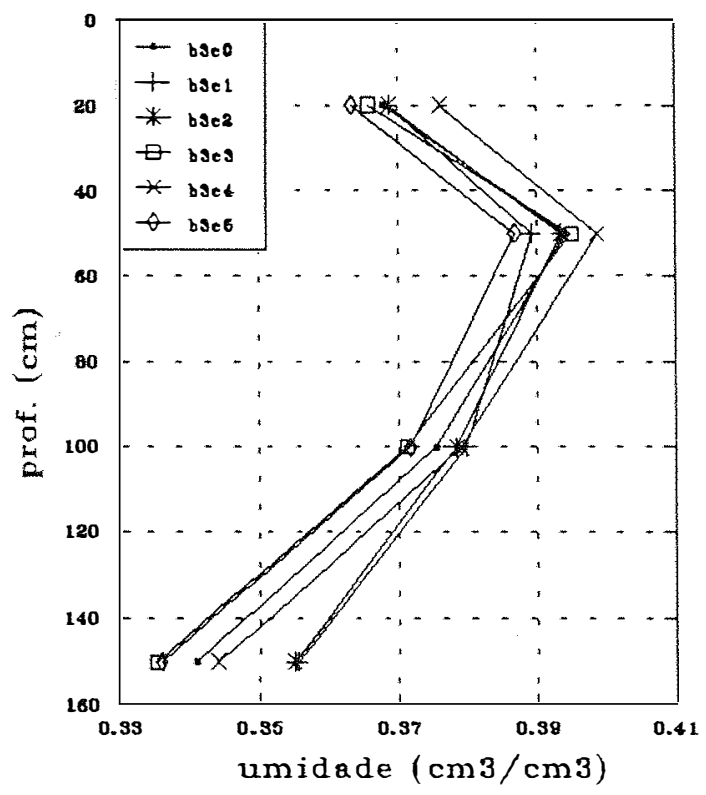

Figura 11. Perfis de umidade nos dias de coleta da atrazina na parcela 2. (A): média da linha 1 ; (B): média da linha 2; (C): média da linha 3. Legenda: b1, b2 e b3 = linhas; $c 0=$ coleta da testemunha e cl a c5 = coletas de solução contendo atrazina. 
(A)

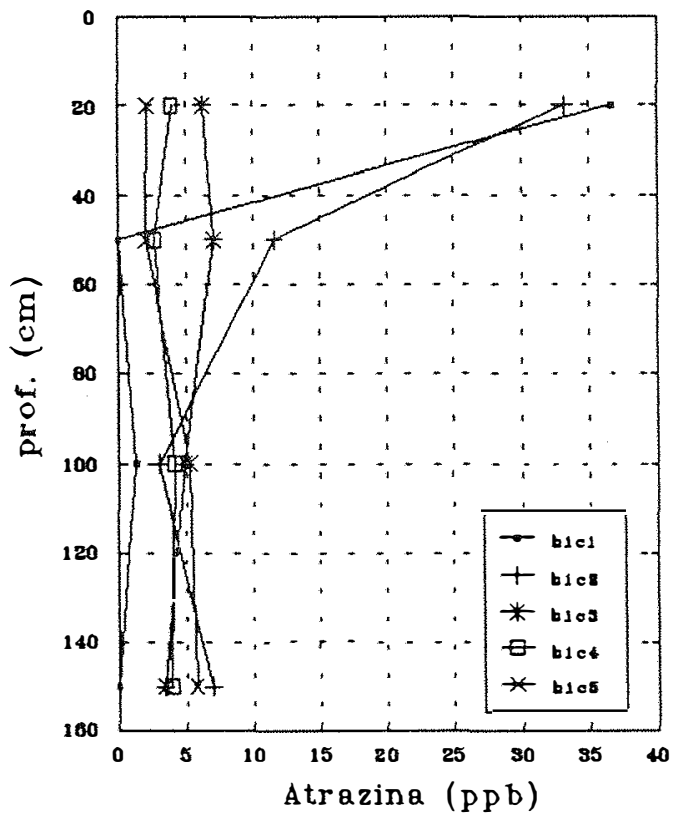

(C)

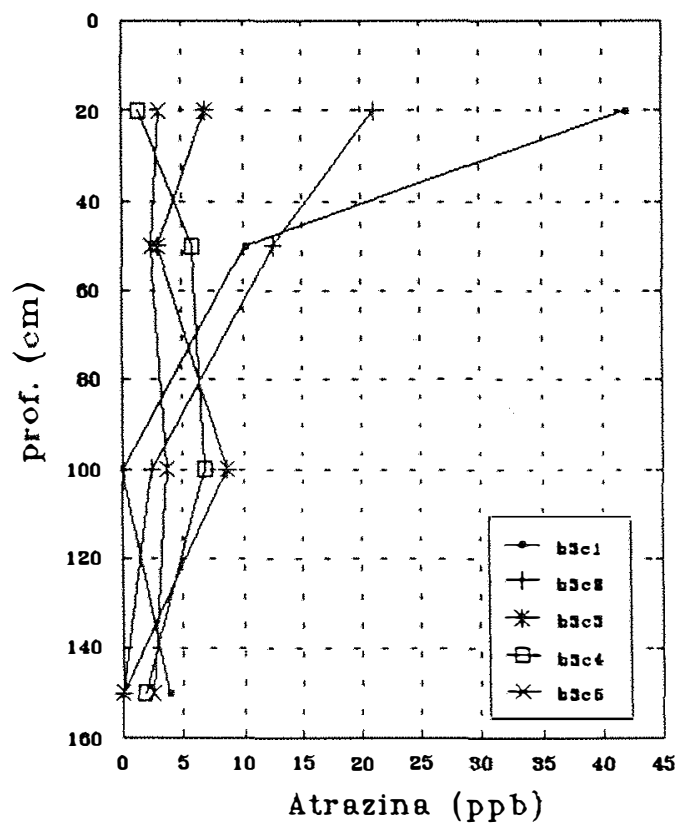

(B)

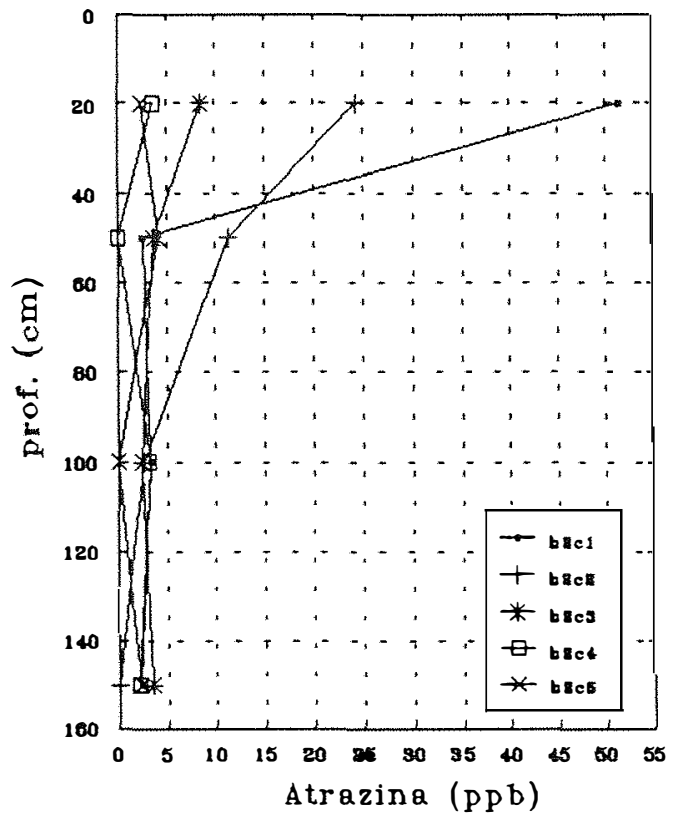

(D)

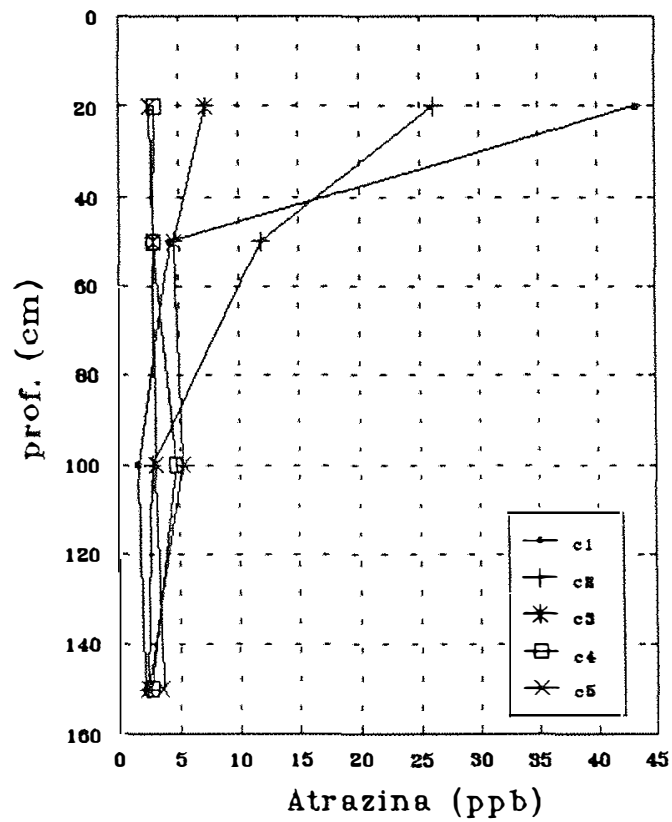

Figura 12. Concentraçāo de atrazina por bateria (A), (B) e (C) e concentraçāo média da parcela 2 (D). (A)=bateria 1 formada pelos três conjuntos de extratores da linha 1; (B) bateria 2 formada pelos três conjuntos de extratores da linha do meio; (C)=bateria 3 formada pelos três conjuntos de extratores da linha três. Legenda: b1, b2 e b3 = baterias; $c 1$ a $c 5=$ coletas. 
Tabela 7. Perdas de atrazina por lixiviacao $\left(\mu \mathrm{g} / \mathrm{m}^{2}\right)$ por linha (L1, L2 e L3) nas parcelas 1 e 2 no período entre coletas.

\begin{tabular}{|c|c|c|c|c|c|c|}
\hline \multirow[b]{3}{*}{ coleta } & \multicolumn{3}{|c|}{ parcela 1} & \multicolumn{3}{|c|}{ parcela 2} \\
\hline & \multicolumn{3}{|c|}{ prof. $(\mathrm{cm})$} & \multicolumn{3}{|c|}{ prof. $(\mathrm{cm})$} \\
\hline & 50 & 100 & 150 & 50 & 100 & 150 \\
\hline $\begin{array}{r}1 \\
\text { LI } \\
2 \\
3 \\
4 \\
5\end{array}$ & $\begin{array}{r}4.00 \\
592.14 \\
303.80 \\
5191.43 \\
25.95\end{array}$ & $\begin{array}{r}111.44 \\
15036.65 \\
1255.93 \\
1246.88 \\
581.51\end{array}$ & $\begin{array}{r}582.39 \\
8042.64 \\
4244.46 \\
9434.83 \\
3501.02\end{array}$ & $\begin{array}{r}0.00 \\
637.93 \\
98.33 \\
488.37 \\
34.81\end{array}$ & $\begin{array}{r}82.82 \\
466.42 \\
27.65 \\
49.54 \\
6.24\end{array}$ & $\begin{array}{r}0.00 \\
37.46 \\
5.92 \\
6.62 \\
2.82\end{array}$ \\
\hline total & 6975.51 & 18232.41 & 25805.33 & 1259.45 & 632.67 & 52.81 \\
\hline $\begin{array}{ll} & 1 \\
& 2 \\
L 2 & 3 \\
& 4 \\
& 5\end{array}$ & $\begin{array}{l}127.78 \\
396.09 \\
729.68 \\
441.85 \\
493.82\end{array}$ & $\begin{array}{r}14690.84 \\
19829.61 \\
6809.38 \\
4158.88 \\
173.07\end{array}$ & $\begin{array}{r}0.00 \\
175.98 \\
12658.77 \\
6680.08 \\
6536.43\end{array}$ & $\begin{array}{r}22.93 \\
58.79 \\
23.89 \\
0.00 \\
1.59\end{array}$ & $\begin{array}{r}35.05 \\
36.09 \\
6.07 \\
40.97 \\
0.00\end{array}$ & $\begin{array}{r}26.41 \\
0.00 \\
17.90 \\
16.04 \\
4.78\end{array}$ \\
\hline total & 2189.23 & 45661.77 & 26051.25 & 107.20 & 118.18 & 65.12 \\
\hline 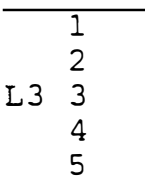 & $\begin{array}{l}404.36 \\
460.66 \\
384.37 \\
314.07 \\
133.50\end{array}$ & $\begin{array}{r}1655.00 \\
5879.93 \\
13386.56 \\
6860.89 \\
3196.77\end{array}$ & $\begin{array}{r}33804.23 \\
11275.20 \\
2216.14 \\
0.00 \\
2733.05\end{array}$ & $\begin{array}{r}68.38 \\
209.35 \\
65.23 \\
346.80 \\
9.68\end{array}$ & $\begin{array}{r}0.00 \\
56.21 \\
260.70 \\
290.41 \\
49.98\end{array}$ & $\begin{array}{r}79.76 \\
0.00 \\
0.00 \\
14.28 \\
5.95\end{array}$ \\
\hline total & 1696.96 & 30979.14 & 50028.62 & 699.44 & 657.30 & 100.00 \\
\hline
\end{tabular}

Figura 7 pode-se observar o comportamento do potencial total de água no solo, nas três baterias de tensiômetros da parcela 1. Verifica-se que para cada linha de instrumentos e em qualquer coleta tem-se um gradiente de potencial total positivo (leitura da camada superior menos leitura da camada inferior e divide-se o resultado pelo intervalo de profundidade). Como o sinal do gradiente é oposto ao sinal do fluxo, isto indica que o fluxo tem sinal negativo e, portanto, é descendente, ou seja, houve apenas drenagem 
60.

durante o período de coleta. Este mesmo comportamento pode ser observado para a parcela dois (Figura 10).

$\mathrm{Na}$ Figura 8 verifica-se que a umidade volumétrica oscilou pouco entre coletas, principalmente na bateria 2 (Figura 8B) e bateria 3 (Figura 8C) e teve uma pequena variação na bateria 1 (Figura 8A) nas profundidades de 100 e $150 \mathrm{~cm}$, refletindo diferenças no meio poroso dentro da parcela. Na profundidade de $50 \mathrm{~cm}$ o deslocamento dos perfis de umidade para a direita (já mencionado) coincide com uma camada (B textural) com teor de argila mais elevado.

Na Figura 9 tem-se as concentrações de atrazina encontradas na solução do solo para cada coleta, em cada linha de extratores e a média da parcela 1. Comparando as três linhas de instrumentos de coleta da parcela entre si pode-se observar que na primeira coleta (linha marcada com ponto) efetuada sete dias após a aplicação, a lixiviação de atrazina foi bastante diferenciada, chegando em pequena quantidade (5ppb) a $150 \mathrm{~cm}$ de profundidade na linha 1 , em grande quantidade (130ppb) a $100 \mathrm{~cm}$ de profundidade na linha do meio e foi encontrado um pico máximo de atrazina a $150 \mathrm{~cm}$ de profundidade (Figura 9C) na linha ou bateria 3 . A concentração de atrazina na profundidade de $150 \mathrm{~cm}$ aumentou ao longo do tempo nas linhas um e dois (Figuras 9A e 9B, respectivamente) e diminuiu na mesma profundidade na linha três que teve sua mais alta concentração já na primeira coleta. Isto sugere que a perda por lixiviação foi maior no 
lado da parcela onde se encontrava a linha três. Como se pode observar na Tabela 7, a perda total foi maior na linha três, indicando condições de fluxo preferencial desse lado.

$$
\text { Ao analisar-se os dados da parcela } 2 \text { (Figuras }
$$

10, 11 e 12) verifica-se que as condições de potencial total de água no solo (Figura 10) são similares às condições da parcela 1, ou seja, o gradiente de potencial total é sempre positivo e, portanto, só houve fluxo descendente. Também houve pouca variação da umidade volumétrica durante as coletas (Figura 11). Mas, os perfis de concentração de atrazina (Figura 12) mostram um comportamento bastante diferente da parcela 1. Na parcela 2 a atrazina apresentou concentrações muito menores em todo o perfil em comparação com a parcela 1. As maiores concentrações foram observadas na profundidade de $20 \mathrm{~cm}$, mas baixaram rapidamente ao longo do período de coletas e não houve muita variação entre as três linhas de extratores, mostrando uma maior homogeneidade desta parcela.

A parcela 1 que recebeu calcário e gesso para elevar a saturação de bases para 88\%, deveria apresentar maior lixiviação de atrazina, pois segundo BAILEY et alii (1968) a elevação do pH reduz a capacidade do solo em adsorver a atrazina, facilitando a lixiviação. Foi constatada baixa capacidade de adsorção (Tabela 8) e adsorção praticamente nula abaixo dos $60 \mathrm{~cm}$ nas duas parcelas, contribuindo para o rápido movimento de atrazina no perfil, 
pois segundo GREEN \& OBIEN (1969) em solos com baixa capacidade de adsorção, variações no conteúdo de água do solo alteram significativamente a concentração do herbicida, facilitando seu movimento no perfil.

Como o teor de água era alto, contribuições de água via precipitação ou irrigação drenam rapidamente e podem carregar a atrazina. Como pode ser observado na Tabela 3, a drenagem da água livre na parcela 2 foi em média 1,44 vezes maior que na parcela 1, e se descartarmos a última determinação este valor sobe para 3,47 vezes. Ainda levando em conta que no terceiro dia após: a aplicação houve uma chuva de $34,4 \mathrm{~mm}$ e no sétimo dia houve outra de $34,9 \mathrm{~mm}$, totalizando um excedente hídrico de $55 \mathrm{~mm}$, é provável que a maior parte da atrazina da parcela 2 tenha lixiviado para profundidades maiores que $150 \mathrm{~cm}$, por fluxo de massa, que segundo GUTH et alii (1977) é o principal mecanismo de transporte deste produto e, em função disto, tenha apresentado baixas concentraçōes no perfil.

Na Tabela 7 pode-se verificar que, em função da baixa concentração encontrada no perfil da parcela 2, as perdas totais obtidas pela multiplicação do fluxo pela concentração e pelo intervalo de tempo apresentam valores bem inferiores aos encontrados na parcela 1 onde a atrazina se distribuiu por todo o perfil; conseqüentemente, os resultados da multiplicação são bem maiores, na parcela 1 . 
4.4. Adsorção e dessorção de atrazina

Os resultados obtidos para adsorção e dessorção de atrazina são apresentados juntamente com o ajuste feito pelo modelo de Freundlich na Tabela $8 \mathrm{~A}$ para a adsorção e na Tabela 8B para dessorção.

Os resultados da Tabela 8 mostram que a adsorção da atrazina foi muito baixa em comparação com dados de literatura. DUNIGAN \& MCINTOSH (1971) encontraram adsorção de atrazina de $77,5 \mu \mathrm{g} / \mathrm{g}$ em solo franco siltoso e deste total, $37,5 \mu \mathrm{g} / \mathrm{g}$ foram devidos à matéria orgânica presente no solo na quantidade de $2,5 \%$. REINHARD et alii (1990), HUANG et alii (1984) também ressaltam o importante papel da matéria orgânica do solo na adsorção de atrazina. Porém, ao elevar-se $\circ \mathrm{pH}$ do solo, aumentam-se as cargas negativas dependentes de pH da matéria orgânica, elevando-se a CTC, mas a elevação do pH diminui o número de cargas positivas da atrazina e 0 resultado final é a diminuição da adsorção. Apesar de ser baixa, a adsorção foi maior na camada de $0-30 \mathrm{~cm}$ onde predomina a maior percentagem de matéria orgânica do solo $(2,7 \%$ de $0-15 \mathrm{~cm}$ e $1,6 \%$ de $15-30 \mathrm{~cm})$. Abaixo de $60 \mathrm{~cm}$ de profundidade a percentagem de matéria orgânica é muito baixa; este fato associado ao elevado $\mathrm{pH}$ em todo o perfil contribuiu para a baixa adsorção de atrazina.

Utilizando o critério de adsorção de BAILEY et alii (1968) que adotaram $\circ$ valor de $K$ da equação de 
Tabela 8. Valores de adsorção (A) e dessorção (B) de atrazina, determinados por cintilação, e ajuste feito pelo modelo de Freundich.

(A)

\begin{tabular}{|c|c|c|c|c|c|c|}
\hline profundidade & conc. & $\mathrm{dpm} / \mathrm{am}$ & $\mathrm{dpm} / \mathrm{pd}$ & $(p d-a m) 10$ & gads. & $\mu \mathrm{g} / \mathrm{g}_{\mathrm{solo}}$ \\
\hline & 0.50 & 10764.27 & 11522.20 & 11368.95 & 9.87 & 0.49 \\
\hline & 1.00 & 10735.18 & 11905.18 & 11700.05 & 9.83 & 0.98 \\
\hline \multirow[t]{4}{*}{$0-30$} & 5.00 & 10936.04 & 11773.14 & 8371.00 & 7.11 & 3.56 \\
\hline & 10.00 & 11336.62 & 11871.30 & 5346.80 & 4.50 & 4.50 \\
\hline & 0.50 & 11291.30 & 11522.20 & 3463.58 & 3.01 & 0.15 \\
\hline & 1.00 & 11262.46 & 11905.18 & 6427.20 & 5.40 & 0.54 \\
\hline \multirow[t]{4}{*}{$30-60$} & 5.00 & 11472.06 & 11773.14 & 3010.80 & 2.56 & 1.28 \\
\hline & 10.00 & 11696.58 & 11871.30 & 1747.20 & 1.47 & 1.47 \\
\hline & 0.50 & 11327.91 & 11493.62 & 1657.10 & 1.44 & 0.07 \\
\hline & 1.00 & 11621.10 & 11827.67 & 2065.75 & 1.74 & 0.17 \\
\hline \multirow[t]{4}{*}{$60-105$} & 5.00 & 11848.94 & 11722.44 & -1265.00 & -1.08 & -0.54 \\
\hline & 10.00 & 12401.15 & 11873.38 & -5277.70 & -4.44 & -4.44 \\
\hline & 0.50 & 11618.11 & 11493.62 & -1244.90 & -1.08 & -0.05 \\
\hline & 1.00 & 11705.50 & 11827.67 & 1221.60 & 1.03 & 0.10 \\
\hline \multirow[t]{2}{*}{$105-165$} & 5.00 & 11759.50 & 11722.44 & -370.80 & -0.32 & -0.16 \\
\hline & 10.00 & 12471.38 & 11873.38 & $3-5980.00$ & -5.04 & -5.04 \\
\hline $\ln x /$ & \multirow{2}{*}{$\begin{array}{l}\operatorname{lnX} / M=- \\
\ln x / M=-\end{array}$} & $28+07$ & $8 \operatorname{lnc}$ & $R^{\wedge} 2=0.98$ & & \\
\hline $\ln x$ & & $72+0$ & $339 \mathrm{lnc}$ & $R^{\wedge} 2=0.88$ & & \\
\hline
\end{tabular}

(B)

\begin{tabular}{|c|c|c|c|c|c|c|}
\hline cofundidade & conc. & $\mathrm{dpm} / \mathrm{am}$ & $\mathrm{dpm} / \mathrm{pd}$ & dpm/res. & gdess. & $\mu \mathrm{g} / \mathrm{g}_{\mathrm{s}}$ \\
\hline & 0.50 & 1489.05 & 11522.20 & 807.23 & 5.92 & 0.30 \\
\hline & 1.00 & 1390.63 & 11905.18 & 762.50 & 5.28 & 0.53 \\
\hline \multirow[t]{4}{*}{$0-30$} & 5.00 & 1234.63 & 11773.14 & 694.44 & 4.59 & 2.29 \\
\hline & 10.00 & 1047.04 & 11871.30 & 679.84 & 3.09 & 3.09 \\
\hline & 0.50 & 1137.64 & 11522.20 & 813.53 & 2.81 & 0.14 \\
\hline & 1.00 & 977.30 & 11905.18 & 765.77 & 1.78 & 0.18 \\
\hline \multirow[t]{4}{*}{$30-60$} & 5.00 & 1027.39 & 11773.14 & 837.46 & 1.61 & 0.81 \\
\hline & 10.00 & 1033.95 & 11871.30 & 871.40 & 1.37 & 1.37 \\
\hline & 0.50 & 1013.46 & 11493.62 & 795.78 & 3.13 & 0.14 \\
\hline & 1.00 & 1123.60 & 11827.67 & 748.79 & 2.83 & 0.30 \\
\hline \multirow[t]{4}{*}{$60-105$} & 5.00 & 1172.30 & 11722.44 & 834.92 & 2.22 & 1.02 \\
\hline & 10.00 & 1206.60 & 11873.38 & 985.90 & 1.62 & 2.00 \\
\hline & 0.50 & 1155.10 & 11493.62 & 294.09 & 2.09 & 0.16 \\
\hline & 1.00 & 1083.44 & 11827.67 & 558.42 & 2.18 & 0.28 \\
\hline \multirow[t]{2}{*}{$105-165$} & 5.00 & 1094.98 & 11722.44 & 659.89 & 1.90 & 1.11 \\
\hline & 10.00 & 1178.26 & 11873.38 & 554.99 & 1.90 & 1.62 \\
\hline t & & & & 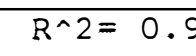 & & \\
\hline & & & (ה) & $R^{\wedge} 2=$ & & \\
\hline
\end{tabular}

$\mathrm{dpm} / \mathrm{am}=$ desintegraçōes por minuto na amostra; $\mathrm{dpm} / \mathrm{pd}=$ desintegraçōes por minuto no padrāo;

$(\mathrm{pd}-\mathrm{am})=$ leitura do padrão - leitura da amostra;

* = equação de Freundlich linearizada. 
65 .

Freundlich, quando a concentração da solução de equilíbrio é igual a um, como parâmetro de comparação, os valores de $\mathrm{K}$ obtidos na Tabela $8 \mathrm{~A}$ quando se substitui o "C" da equação por 1, são de 0,91 $\mu \mathrm{g} / \mathrm{g}$ de solo e 0,36 $\mu \mathrm{g} / \mathrm{g}$ de solo, respectivamente para as profundidades $0-30 \mathrm{~cm}$ (amostra um) e 30-60 cm (amostra dois) contra um valor de $\mathrm{K}$ igual a $15 \mu \mathrm{g} / \mathrm{g}$ de solo encontrado por BAILEY et alii (1968) para a atrazina. ou seja, a Terra Roxa adsorveu 16,48 vezes menos que a montmorilonita estudada pelos autores.

Quanto à dessorção (Tabela 8B), verifica-se que 65\% do total adsorvido na camada de $0-30 \mathrm{~cm}$ foram liberados durante o processo de dessorção, isto é, a capacidade de retenção da atrazina na primeira camada foi de $35 \%$ e na segunda de $27 \%$. Isto indica que além de ser muito baixa a adsorção, o pouco que ficou adsorvido é facilmente liberado para a solução do solo.

Em resumo, a Terra Roxa Estruturada, nas condições em que foi feito o experimento, apresentou grande capacidade de lixiviação de atrazina, com conseqüentes riscos de contaminação do lençol freático, corroborando os resultados de BACCI et alii (1989), que registraram a presença de atrazina até $320 \mathrm{~cm}$ de profundidade e a consideraram como um composto de alto risco de contaminação.

4.5. Lixiviação do cloreto e do potássio 
66.

A variação de potencial total de água da parcela 1 no período de coleta de cloreto e potássio pode ser observada na Figura 13, sendo que a leitura de tensiometros da quarta coleta (b1c4, b2c4, b3c4) foi efetuada no dia em que se fez vácuo para a coleta número cinco.

Na Figura 14 são apresentados os resultados obtidos para potássio em profundidade na parcela 2, por linha e a média da parcela toda. Na Figura 15 podem ser vistos da mesma forma os resultados para cloreto em solução do solo na parcela 1 .

Da mesma forma que foram apresentados os resultados da parcela 1, e na mesma ordem, podem ser observados para a parcela 2: o potencial total de água no solo na Figura 16; as concentrações de potássio e de cloreto por coleta e por profundidade respectivamente nas Figuras 17 e 18. Os resultados individuais (por extrator) encontram-se nos Apêndices 4 (potássio) e 5 (cloreto).

A exemplo do que foi feito para atrazina, podese verificar na Figura 13 que o potencial total de água no solo na parcela 1 indica fluxo de água descendente durante o período de coleta de solução do solo para determinação de potássio e cloreto, não havendo muita variação entre coletas, e também entre baterias.

Pela Figura 14 verifica-se que houve lixiviação do potássio até $150 \mathrm{~cm}$ de profundidade para as três linhas de instrumentos (baterias A, B e C) já na primeira coleta 
(A)

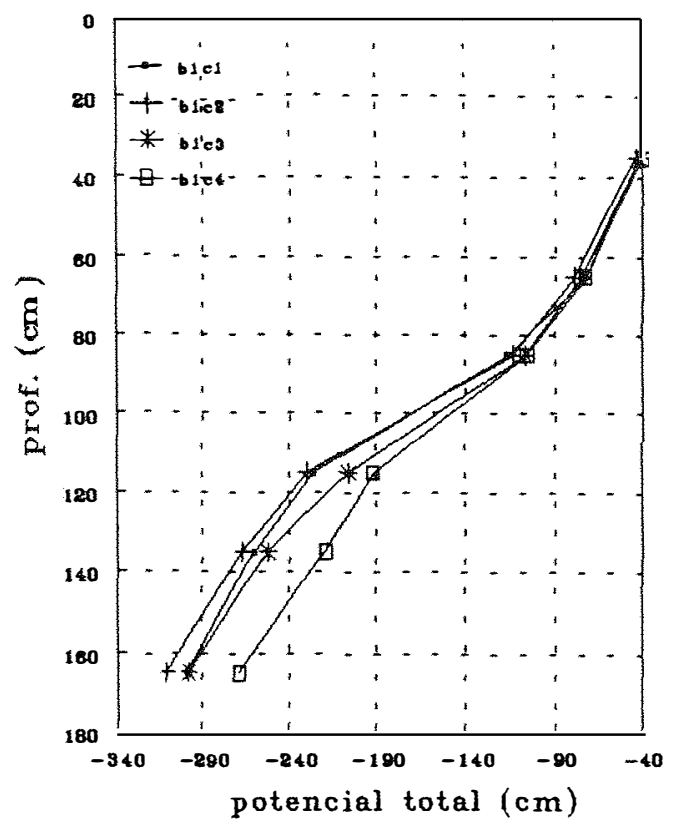

(B)

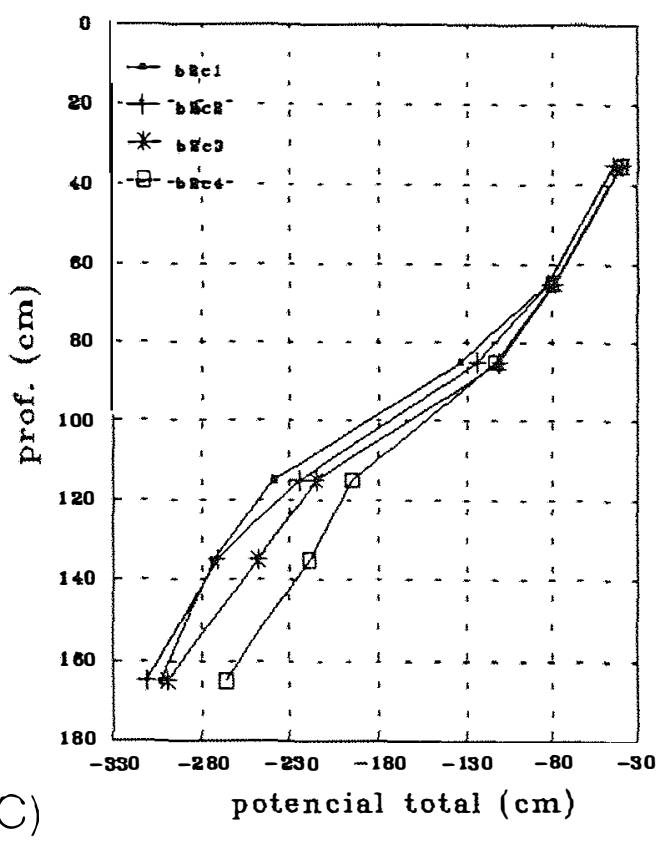

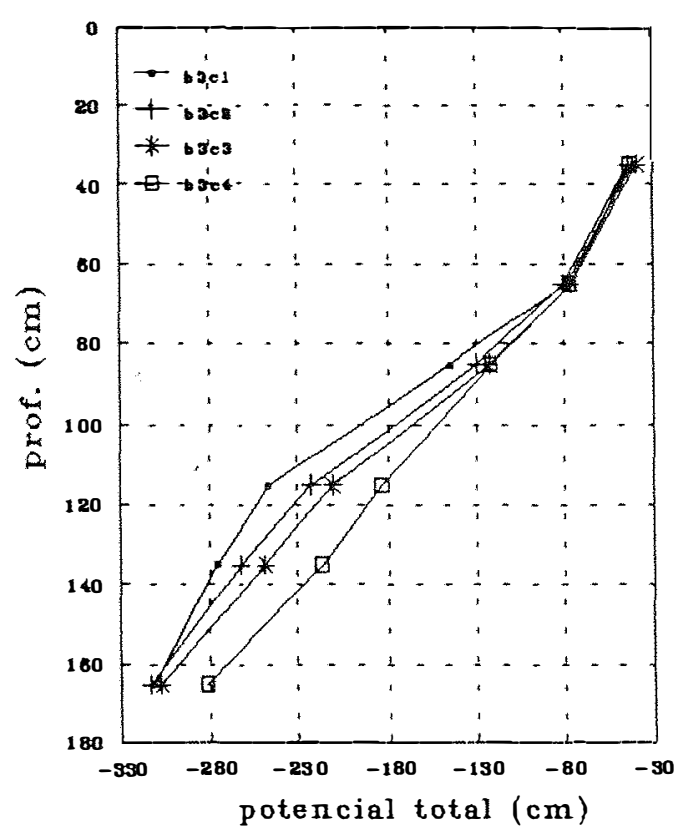

Figura 13. Potencial total de água no solo na parcela 1 no período de coleta de cloreto e de potássio. (A): média da linha 1; (B):média da linha 2; (C): média da linha 3. Legenda: b1, b2 e b3 = linhas; $c 1$ a c5 = coletas de soluçāo do solo para cloreto e potássio. 

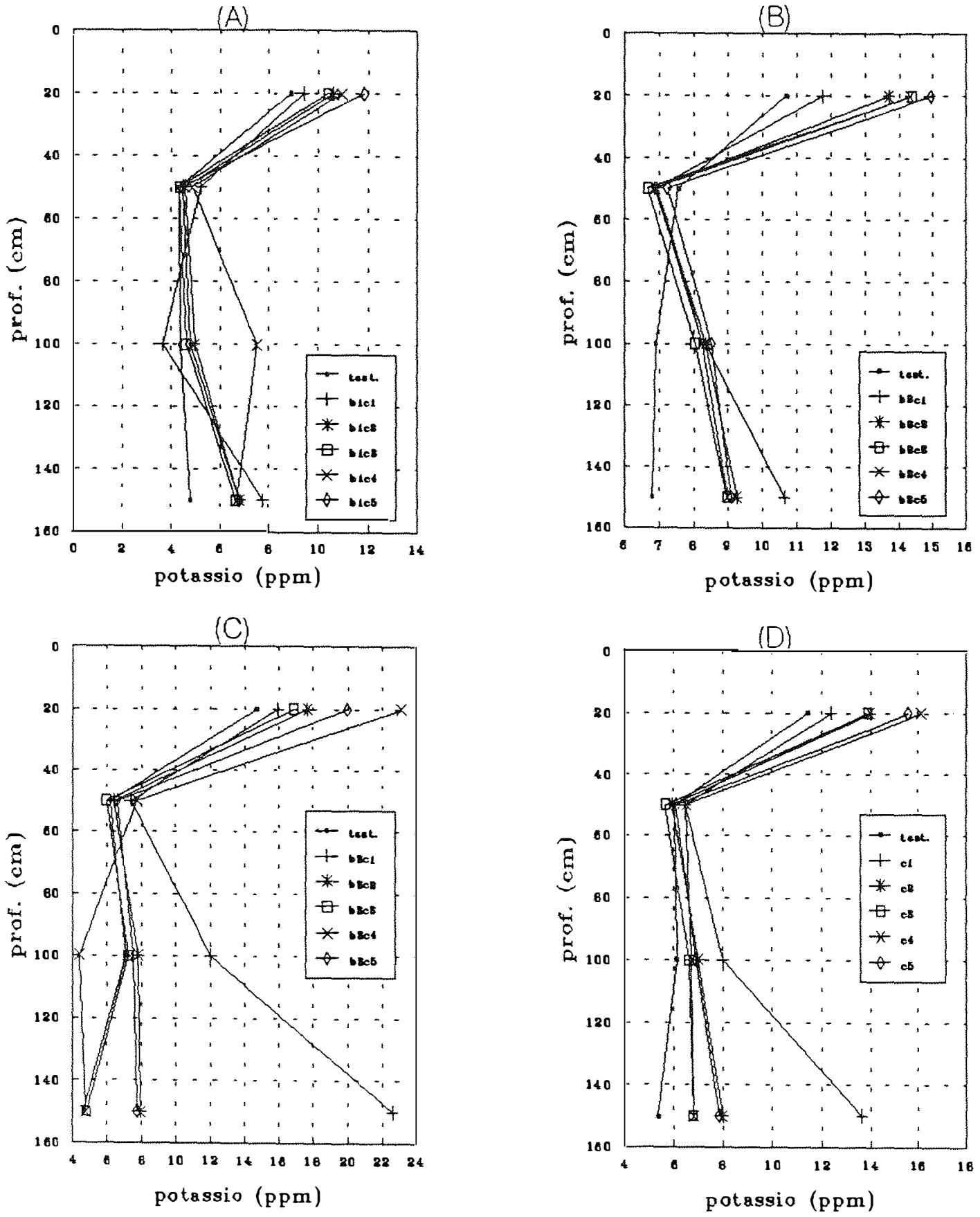

Figura 14. Concentraçāo de potássio na soluçāo do solo por linha (A), (B), (C) e média da parcela 1 (D). Onde: (A), (B) e (C) são médias dos extratores nas linhas 1,2 e 3 respectivamente. 
(A)

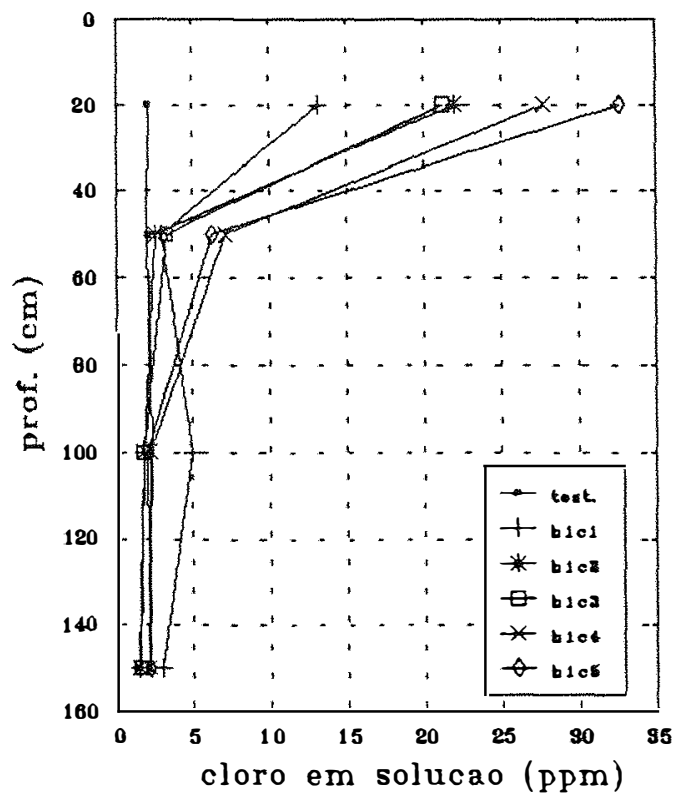

(C)

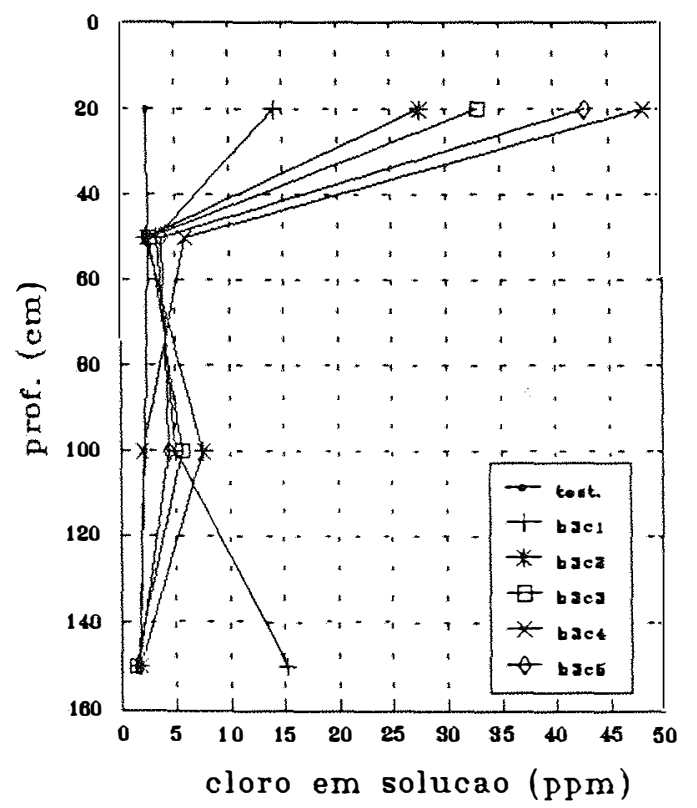

(B)

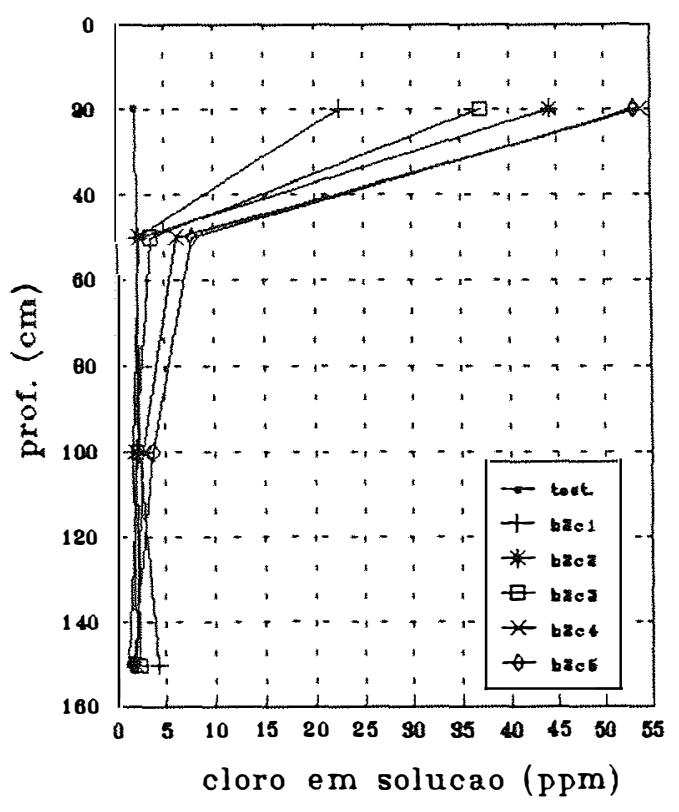

(D)

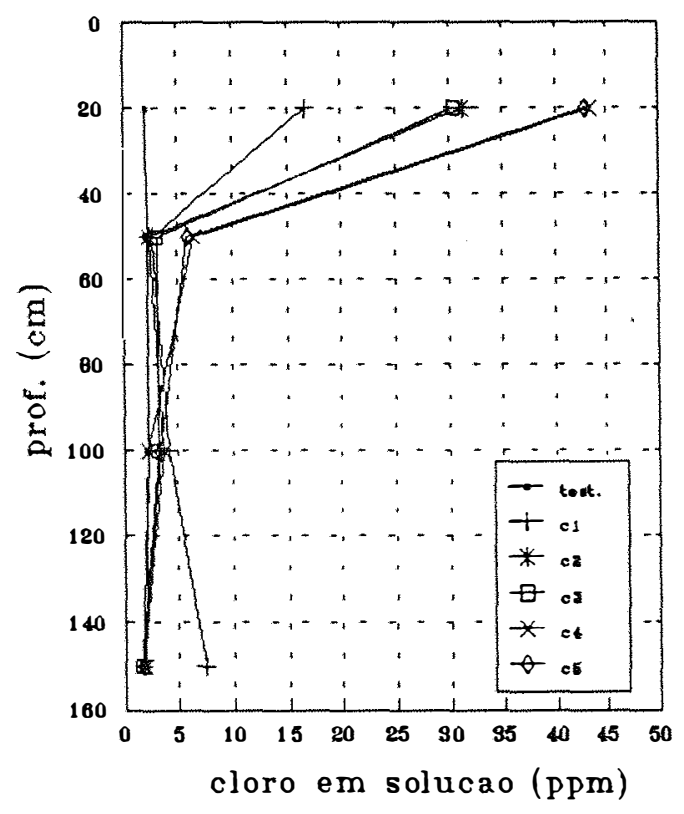

Figura 15. Concentração de cloreto na solução do solo por linha (A), (B), (C) e média da parcela 1 (D). (A): média da linha $1 ;(B)$ : média da linha $2 ;(C)$ : média da linha 3. Legenda: b1, $b 2$ e b3 = linhas; $c 1$ a $c 5=$ coletas de solução do solo contendo cloreto e potássio. 
(A)

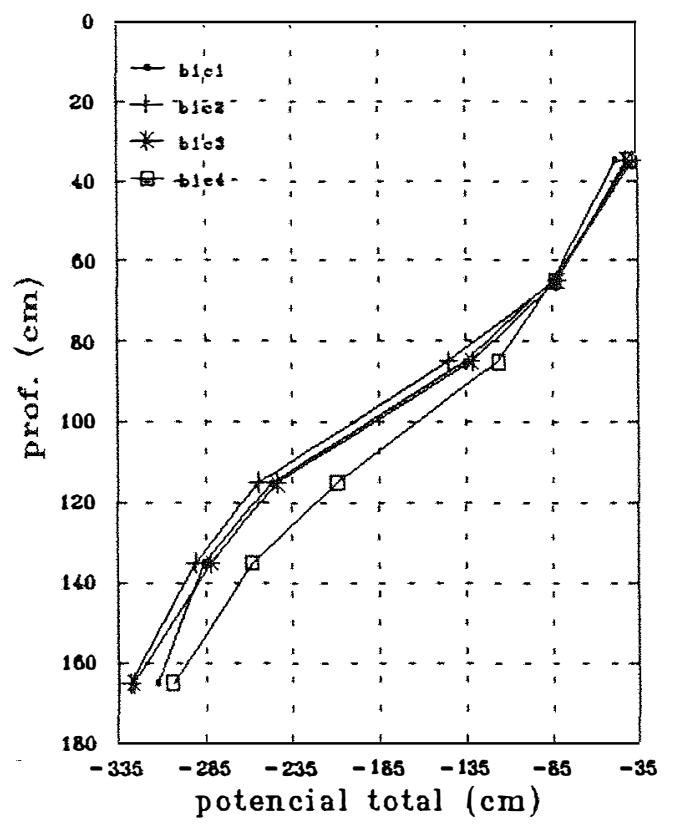

(B)

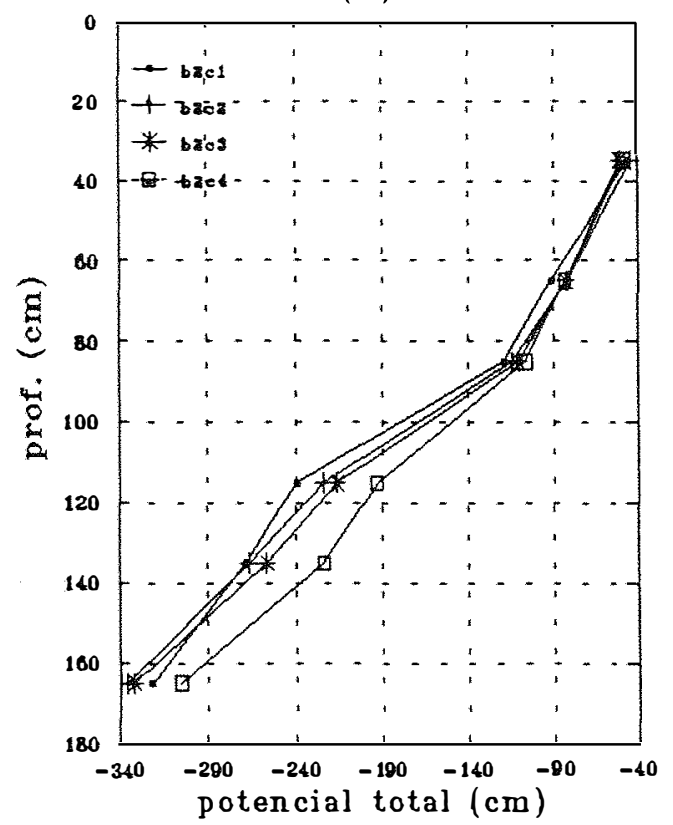

(C)

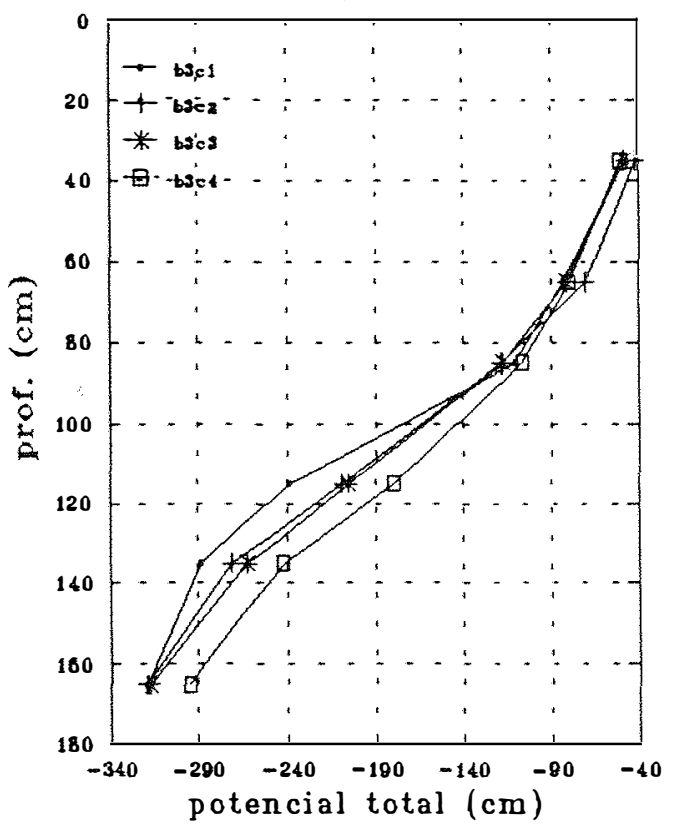

Figura 16. Potencial total de água no solo na parcela 2 no periodo de coleta de cloreto e potássio. (A): média da linha I; (B): média da linha 2; (C): média da linha 3 . Legenda: b1, $b 2$ e b3 = linhas; $c 1$ a $c 4=$ dias de coletas. 

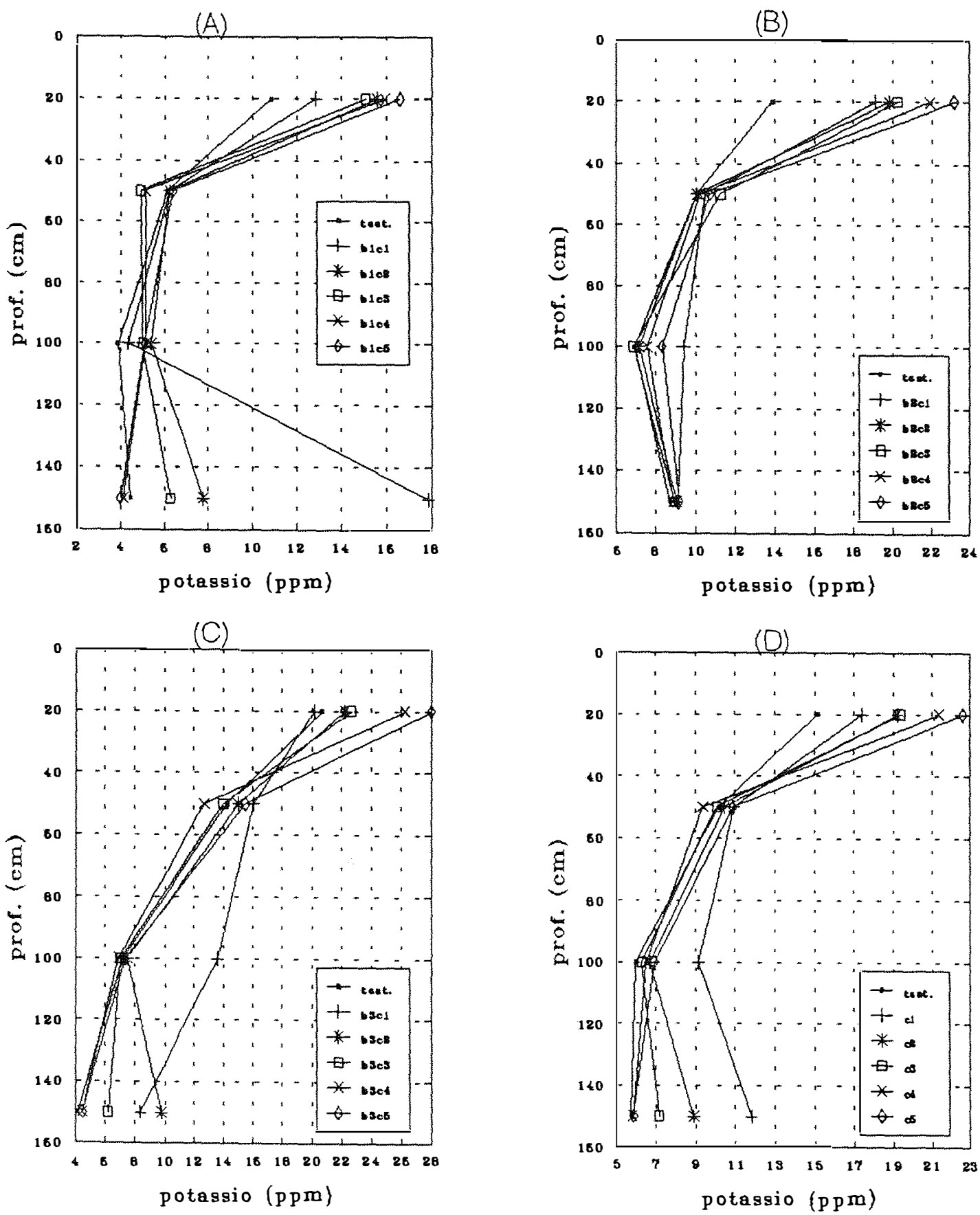

Figura 17. Concentração de potássio na solução do solo por linha. (A): média da linha $1 ;(B)$ : média da linha $2 ;(C)$ : médi da linha $3 ;$ (D): média da parcela 2. Legenda: b1, b2, b3= linhas, $c l$ a $c 5=$ coletas de solução do solo contendó potassio e test. = testemunha. 
(A)

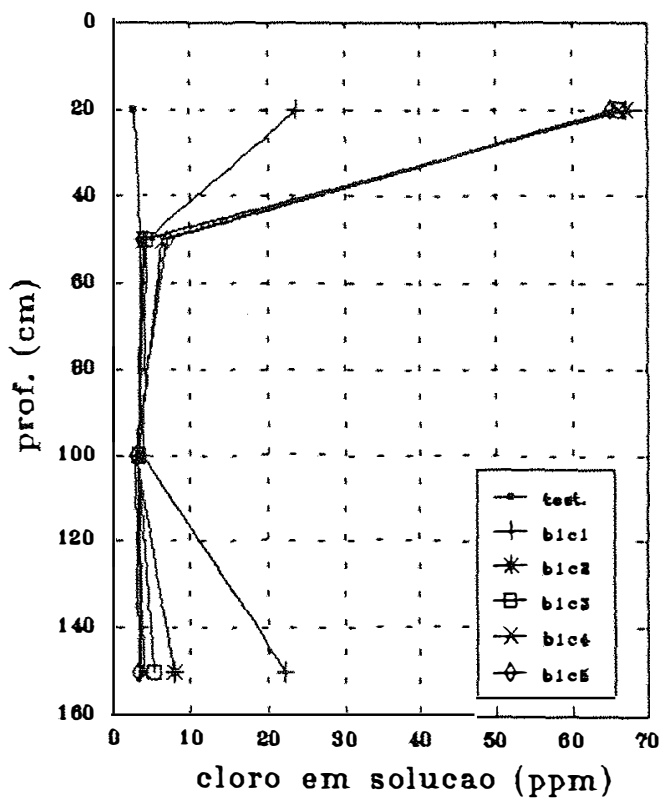

(C)

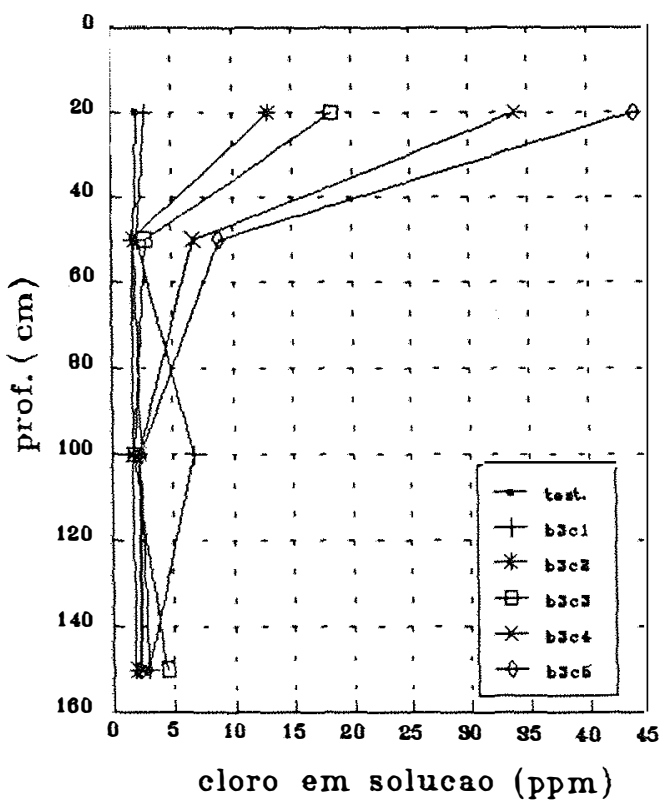

(B)

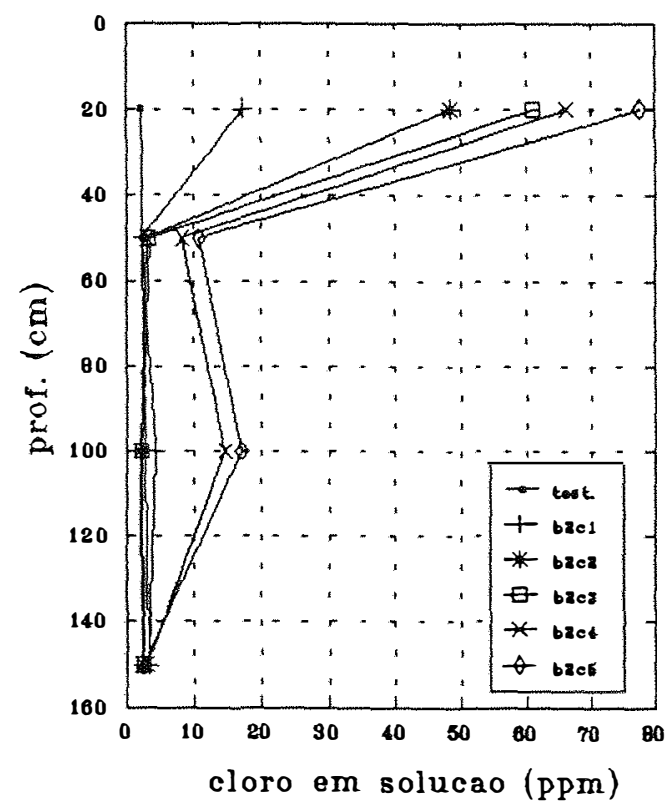

(D)

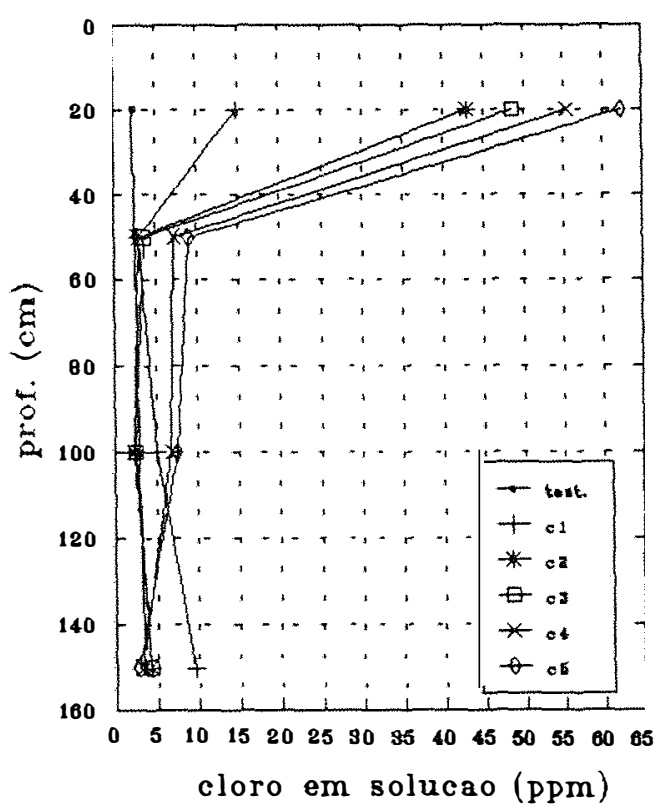

Figura 18. Concentração de cloreto na solução do solo na parcela 2. (A): média da linha $1 ;$ (B): média da linha 2 ; $(C)$ : média da linha 3; (D): média da parcela 2. Legenda: b1, b2, b3= linhas, $c 1$ a $c 5=$ coletas de solução do solo contendo cloreto e test. = testemunha. 
ocorrida cinco dias após a aplicação do cloreto de potássio. Até este dia houve um excedente hídrico de $32 \mathrm{~mm}$ (Figura 5) e ao final, na quinta coleta, o excedente hídrico foi de $100 \mathrm{~mm}$ de água. Na linha 3 da parcela 1 (Figura 14C) observa-se que na primeira coleta houve um pico de potássio a $150 \mathrm{~cm}$ de profundidade, repetindo o comportamento da atrazina nesta mesma linha. Como no caso do potássio, a coleta foi individualizada para cada extrator, buscando encontrar fluxo preferencial causado possivelmente por fendas, a análise destes dados (Apêndice 4) revela que no extrator número 28 houve fluxo preferencial.

Efeito semelhante pode ser observado para o cloreto (Figura 15C). As maiores concentrações de cloreto a $150 \mathrm{~cm}$ de profundidade foram obtidas na primeira coleta (Figuras 15A, 15B e 15C).

$\mathrm{Na}$ parcela 2 o fluxo também é sempre descendente, como mostra o potencial total de água no solo (Figura 16) com gradiente positivo. Na Figura 17 observa-se que na parcela 2 houve Iixiviação do potássio, também de forma bastante rápida, e o pico máximo obtido cinco dias após a aplicação (primeira coleta) encontra-se na maior profundidade $(150 \mathrm{~cm})$ e na linha um (Figura 17A). Esta concentração foi observada no extrator número 12 da linha um (Apêndice 4) indicando também fluxo preferencial nesta linha. Este tipo de efeito é observado também para o cloreto (Figura 18A, Apêndice 5). Como pode ser visto na Figura 18, houve 
lixiviação do cloreto em todo o perfil, a exemplo do potássio. Isto mostra, como diz RAIJ (1986), que o arraste de ânions no perfil é acompanhado por cátions para manter a eletroneutralidade do sistema.

Tanto para o potássio como para o cloreto houve acúmulo até a profundidade de $20 \mathrm{~cm}$ nas duas parcelas. A quantidade aplicada de potássio na superfície em relação a uma camada de solo de $1 \mathrm{~cm}$ de profundidade foi de $970 \mathrm{ppm}$ para o cloreto e $1.070 p p m$ para o potássio, e em relação ao teor de água nesta mesma camada a concentração de potássio foi de $2.890 \mathrm{ppm}$ e de cloro de $2.770 \mathrm{ppm}$ para um teor de água no solo de $37 \mathrm{~cm}^{3} / \mathrm{cm}^{3}$ no dia da aplicação. Segundo o que afirmam EVANS \& LEVIN (1968), em solo não saturado, o avanço do pico de sais é consideravelmente retardado em relação ao avanço da frente de molhamento; é possível que o aumento crescente em cada coleta na profundidade de $20 \mathrm{~cm}$ indique que a grande massa de cloreto e potássio esteja na profundidade de $0-20 \mathrm{~cm}$ após 20 dias da aplicação.

A concentração de potássio no solo em todo o perfil para as duas parcelas estava alta (Tabela 1) antes da aplicação e isso pode ter contribuído também para a lixiviação, além do teor alto de umidade no solo que cria condiçōes bastante favoráveis para que o excedente hídrico aplicado flua livremente por ação gravitacional por todo o perfil, carregando por fluxo de massa os sais solúveis, pois é segundo REICHARDT (1986) um dos principais mecanismos de 
75.

arraste de ions no perfil. 
5. CONCLUSÕES

Nas condições em que foi realizado este trabalho, a análise dos dados obtidos permite estabelecer as seguintes conclusões:

a) a aplicação de atrazina em Terra Roxa Estruturada com teor de água e pH altos pode levar a perdas significativas do produto, atingindo regiões fora do alcance das raízes, com conseqüente risco de contaminação do lençol freático;

b) a existência de fendas no solo pode contribuir para a ocorrência de fluxo preferencial, aumentando as perdas de atrazina, de cloreto e de potássio por lixiviação;

c) a utilização de cloreto e de potássio como traçadores é viável em estudos de movimentação de atrazina e como indicadores de fluxo preferencial nas condições estudadas;

d) devido ao caráter expansivo do solo, os resultados obtidos com o método do anel para medição de condutividade hidráulica do solo saturado apenas refletem o momento da medição, e

e) os resultados obtidos para o fluxo de água 
77.

em condiçōes insaturadas não explicam a movimentação observada para atrazina. 


\section{REFERÊNCIAS BIBLIOGRÁFICAS}

ANDERSON, W.P. Weed science: Principles. West Publishing co., st. Paul, 1983. 655p.

ARMSTRONG, D.E. \& KONRAD, J.G. Nonbiological degradation of pesticides. In: GUENVI, W.D. et alii, eds. Pesticides in soil and water. Madison, Soil science society of America. 3ed. p.123-132. 1986.

BACCI, E.; RENZONI, A.; GAGGI, C.; CALAMARI, D.; FRANCHI, A.; VIGHI, M. \& SEVERJ, A. Models, field studies, laboratory experiments: an integrated approach to evaluate the environmental fate of atrazine (s-triazine herbicides). Agriculture, Ecosystems and environment, $27: 513-522,1989$.

BAILEY, G.W.; HITE, J.L. \& ROTHBERG, T. Adsorption of organic herbicides by montmorillonite: role of $\mathrm{pH}$ and chemical character of adsorbate. Soil Sci. Soc. Am. Proc., Madison, 32(2):222-234, 1968 .

BLAKE, G.; SCHLICHTING, E. \& ZIMMERMAN. Water recharge in 
a soil with shrinkage cracks. Soil sci. Soc. Am. Proc., Madison, 37:669-672, 1973.

BORROTO, J.P.; HERRERA, J.A. \& SOTUYO, C.A. Estudio de la movilidad del potasio en el suelo en columnas de lixiviación. Revista centro Agrícola, Ciego de Avila, $15(2): 80-86,1988$.

BOUMA, J., JONGERIUS, A., BOERSMA, O. , JAGER, . \& SCHONDERBEEK, D. The function of different types of micropores during saturated flow through four swelling soil horizons. Soil Sci. Soc. Am. J., Madison, 41:945950,1977

BR-MA-EMBRAPA-SNLCS. Manual de métodos de análise de solo. Rio de Janeiro. 247p. 1979.

BUSER, H.R. Atrazine and other s-triazine herbicides in lakes and in ruin in switzerland. Environ. Sci. Technol., Wadenswil, 24(7):1049-1058, 1990.

DACHLER, C. Lixiviação nos solos brasileiros. Ciba-Geigy Química, Santo Amaro, 1978. 5p.

DUNIGAN, E.P. \& Mcintosh, T.H. Atrazine-soil organic matter interactions. Weed sci., Ithaca, 19(3):279-282, 
1971.

EVANGELOU, V.P. \& WANG, J. Differences between infrared spectra of atrazine obtained under transmittance and diffuse reflectance modes. Spectrochimica Acta., Lexington, 49A(2):291-295, 1993.

EVANS, G.N. \& LEVIN, I. The distribution of salt by infiltration of water into dry soil and sand. Aust. $J$. Soil Res., Townville, 7:21-27, 1969.

FERREIRA, P.A.; RIBEIRO, A.C.; RIBEIRO DOS SANTOS, C.; HENRIQUES, H.P. \& CAIXETA, T.J. Movimento vertical de nitrato, amônio, cloreto e potássio em colunas de solo irrigado. Revista ceres, Viçosa, 37(210):152-166, 1990.

FRANCO, C.M. \& MEDINA, H.P. Arrastamento de potássio e fósforo pela água de infiltração do solo. Bragantia, Campinas, $19: 73-76,1960$.

GILLMAN, G.P.; BRISTOW, K.L. \& HALLMAN, M.J. Leaching of applied calcium and potassium from an oxisol in Humid Tropical Queensland. Aust. J. Soil Res., Townville, $27: 183-198,1989$.

GREEN, R.E. \& OBIEN, S.R. Herbicide equilibrium in soils 
in relation to soil water content. Weed sci., Ithaca, $17: 514-521,1969$

GUTH, J.A.; GERBER, H.R. \& SCHLAEPFER, T.H. Effect of adsorption, movement and persistence on the biological availability of soil-applied pesticides. proceedings British crop Protection Conference-Pest and Diseases, $961-971,1977$.

HARRIS, C.I. \& WARREN, G.F. Adsorption and desorption of herbicides by soil. Weeds, Champaign, 12:120-126, 1964 .

HARRIS, C.I.; KAUFMAN, D.D. ; SHEETS, T.J.; NASH, R.G. \& KEARNEY, P.C. Behavior and fate of s-triazines in soils. Advan. Pest. Control Res., 8:1-55, 1968.

HUANG, P.M.; GROVER, R. \& MCKERCHER, R.B. Components and particle size fractions involved in atrazine adsorption by soils. Soil sci., New Brunswick, 138:20-24, 1984.

JADCZUK, E. \& ZMUDZIN, J. Leaching of $K$ and Mg out of an alluvial silty loam soil under conditions of increased or restricted water supply. Acta Horticulturae, Warsaw, $274: 207-214,1990$.

KAUFMAN, D.D. Degradation of pesticides by soil 
microorganisms. In: GUENVI, W.D. et alii, eds. pesticides in soil and water. Madison, Soil Science Society of America. 3ed. p.133-202, 1986.

LIBARDI, P.L.; REICHARDT, K. ; NIELSEN, D.R. \& BIGGAR, J.W. Simplified field methods for estimating the unsaturated hydraulic conductivity. Soil Sci. Soc. Am. J., Ann Arbor, 44(1):3-6, 1980 .

NASCIMENTO FILHO, V.F.; REICHARDT, K. \& LIBARDI, P.L. Deslocamento miscível do íon cloreto em terra roxa estruturada (ALFISOL) saturada em condições de campo. Revista Brasileira de Ciência do Solo, Campinas, $3(2): 67-73,1979$.

PHILLIPS, I.R.; BLACK, A.S. \& CAMERON, K.C. Effect of cation exchange on the distribution and movement of cations in soils with variable charge. II. Effect of lime or phosphate on potassium and magnesium leaching. Fertilizer Research, New Zealand, 17:31-46, 1988.

QUISENBERRY, V.L. \& PHILIP, R.E. Percolation of surface applied water in the field. Soil Sci. Soc. Am. J., Madison, 40:484-490, 1976 .

RAHMAN, A. \& MATTHEWS, L.J. Effect of soil organic matter 
83.

on the phytotoxicity of thirteen s-triazine herbicides. Weed sci., Ithaca, $27(2): 158-161,1979$.

RAIJ, B. van \& QUAGGIO, J.A. Métodos de análise de solo para fins de fertilidade. B. Técn. Inst. Agron., Campinas, 1983. 40 .

RAIJ, B. van. Propriedades eletroquímicas de solos. In: Simpósio Avançado de Química e Fertilidade do Solo, 1., Piracicaba, 1986. Anais... Campinas, Fundação Cargill, 1986. p. 9-42.

RALPH, G.N. Solid-size extraction of carbofuran, atrazine, simazine, anachlor, cyanazine from shallow well water. Journal Association of Oss. Anal. Chem., $73(3): 438-442,1990$.

REICHARDT, K. Dinâmica de íons no solo. In: Simpósio Avançado de Química e Fertilidade do Solo, 1., Piracicaba, 1986. Anais... Campinas, Fundação Cargill, 1986. p. 43-52.

REINHARDT, C.F.; EHLERS, J.G. \& NEL, P.C. Persistence of atrazine as affected by selected soil properties. South African Journal of plant and soil, Pretoria, $7(3): 182-187,1990$. 
SERVIÇO NACIONAL DE PESQUISAS AGRONÔMICAS. Levantamento de reconhecimento dos solos do Estado de Sāo Paulo. (Contribuição à Carta de Solos do Brasil). Rio de Janeiro, 1960. 634p. (Boletim, 12).

SMITH, A.E. \& WALKER, A. Prediction of the persistence of the triazine herbbicides atrazine, cyanazine, and metribuzin in regina heavy clay. Can. J. Soil sci., Regina, Canada, $69(3): 587-595,1989$.

SMITH, W.N.; PRASHER, S.O.; KHAN, S.U. \& BARTHAKUR, N.N. Leaching of ${ }^{14} \mathrm{C}$-labellled atrazine in long, intact soil columns. Transactions of the Asae, st. Joseph, $35(4): 1213-1220,1992$.

SUAREZ, V.S. \& CARRILLO, P.I.F. Comportamiento de tres fertilizantes potasicos en un dystrandept tipico. Cenicafé, Caldas, 35(2):31-39, 1984 .

TURATTI, A.L.; VILAGRA, M.M.; PONCE, J.E., BACCHI, O.O.S. \& REICHARDT, K. Variabilidadae espacial do solo e sua implicação na calibração de sondas de nêutrons. R. Bras. Ci. Solo, Campinas, 14:259-262, 1990.

WEBER, J.B. Interaction of organic pesticides with particulate matter in aquatic and soil systems. Adv. 
Chem. Series, Washington, 11:55-120, 1972 .

WEED, S.B. \& WEBERT, J.B. Pesticides organic matter interactions. In: Guenzi, W.D., ed.. Pesticides in soil and water. Soil Sci. Soc. of Amer., Madison, 3866,1974 .

YAMANE, V.K. \& GREEN, R.E. Adsorption of ametryne and atrazine on an oxisol montmorillonite, an chascoal in relation to $\mathrm{pH}$ and solubility effects. Soil sci. soc. Amer. Proceedings, Ann Arbor, 36:58-64, 1972 .

ZAGATTO, E.A.G.; JACINTHO, A.O.; REIS, B.F.; KRUG, F.J.; BERGAMIN FILHO, H.; PESSENDA, L.C.R.; MORTATTI, J. \& GINÉ, M. F. Manual de análises de plantas e águas empregando sistemas de injeção em fluxo. CENA/USP, Piracicaba, 45p. 1981 .

ZINS, A.B.; WYSE, D.I. \& KOSKINEN, W.C. Effect of alfalfa (Medicago sativa) roots on movement of atrazine and alachlor through soil. Weed sci., Ithaca, 39(2):262$269,1991$. 
7. APENNDICES 


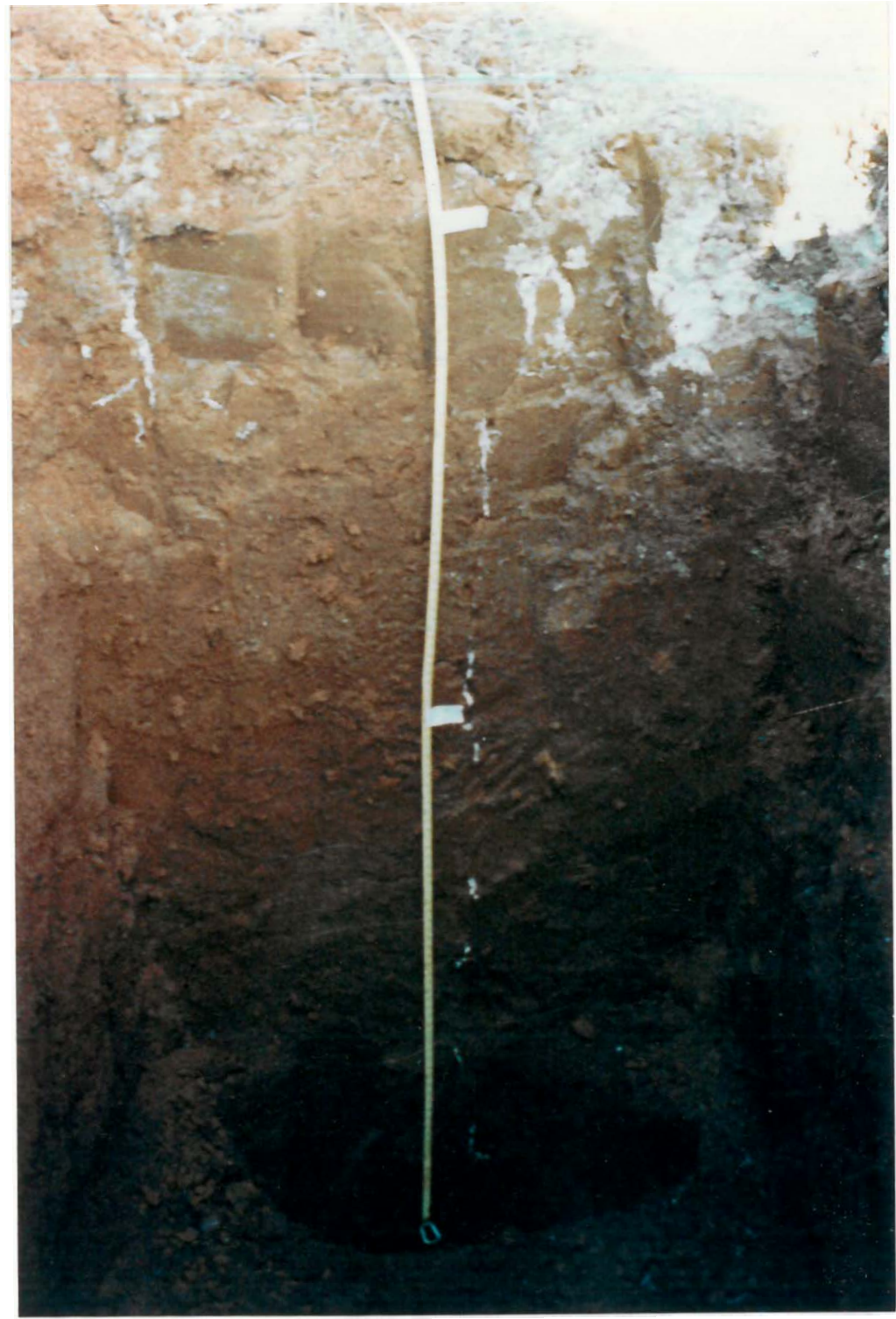

APÊNDICE 1. Detalhes de fluxo preferencial no perfil de solo da Terra Roxa Estruturada. 
APENDICE 2. Valores de teta nas parcelas 1 e 2 utilizados para determinação de $\mathrm{K}(\theta)$.

\begin{tabular}{|c|c|c|c|c|c|c|c|c|c|}
\hline \multirow[b]{2}{*}{ dia } & \multirow[b]{2}{*}{ tubo } & \multicolumn{4}{|c|}{ prof. $(\mathrm{cm})$ parcela 1} & \multirow{2}{*}{$\frac{}{\text { prof. }}$} & \multirow{2}{*}{$\frac{(\mathrm{cm}) \mathrm{p}}{50}$} & \multirow{2}{*}{$\begin{array}{c}\text { parcela } \\
100\end{array}$} & \multirow{2}{*}{$\begin{array}{l}2 \\
150\end{array}$} \\
\hline & & 20 & 50 & 100 & 150 & & & & \\
\hline \multirow{9}{*}{1} & 1 & 0.379 & 0.420 & 0.382 & 0.356 & 0.367 & 0.405 & 0.374 & 0.359 \\
\hline & 2 & 0.376 & 0.407 & 0.395 & 0.355 & 0.375 & 0.420 & 0.373 & 0.358 \\
\hline & 3 & 0.375 & 0.405 & 0.389 & 0.345 & 0.385 & 0.406 & 0.356 & 0.348 \\
\hline & 4 & 0.379 & 0.420 & 0.371 & 0.353 & 0.348 & 0.388 & 0.397 & 0.354 \\
\hline & 5 & 0.384 & 0.420 & 0.375 & 0.364 & 0.371 & 0.403 & 0.370 & 0.377 \\
\hline & 6 & 0.386 & 0.426 & 0.389 & 0.358 & 0.376 & 0.408 & 0.374 & 0.359 \\
\hline & 7 & 0.375 & 0.420 & 0.363 & 0.342 & 0.373 & 0.400 & 0.380 & 0.363 \\
\hline & 8 & 0.370 & 0.429 & 0.379 & 0.353 & 0.362 & 0.388 & 0.397 & 0.359 \\
\hline & 9 & 0.379 & 0.424 & 0.362 & 0.342 & 0.362 & 0.397 & 0.376 & 0.356 \\
\hline \multirow{9}{*}{2} & 1 & 0.375 & 0.410 & 0.371 & 0.350 & 0.365 & 0.403 & 0.373 & 0.353 \\
\hline & 2 & 0.368 & 0.401 & 0.398 & 0.352 & 0.374 & 0.410 & 0.368 & 0.348 \\
\hline & 3 & 0.375 & 0.408 & 0.384 & 0.340 & 0.387 & 0.403 & 0.349 & 0.340 \\
\hline & 4 & 0.371 & 0.418 & 0.367 & 0.350 & 0.348 & 0.384 & 0.380 & 0.352 \\
\hline & 5 & 0.387 & 0.421 & 0.368 & 0.359 & 0.363 & 0.395 & 0.368 & 0.365 \\
\hline & 6 & 0.384 & 0.415 & 0.386 & 0.353 & 0.372 & 0.406 & 0.368 & 0.359 \\
\hline & 7 & 0.374 & 0.413 & 0.356 & 0.345 & 0.371 & 0.398 & 0.378 & 0.349 \\
\hline & 8 & 0.367 & 0.428 & 0.372 & 0.346 & 0.353 & 0.381 & 0.383 & 0.351 \\
\hline & 9 & 0.378 & 0.421 & 0.353 & 0.329 & 0.356 & 0.387 & 0.365 & 0.351 \\
\hline \multirow{9}{*}{3} & 1 & 0.368 & 0.411 & 0.363 & 0.339 & 0.358 & 0.396 & 0.371 & 0.349 \\
\hline & 2 & 0.365 & 0.399 & 0.390 & 0.350 & 0.367 & 0.404 & 0.367 & 0.346 \\
\hline & 3 & 0.376 & 0.406 & 0.390 & 0.337 & 0.390 & 0.408 & 0.348 & 0.331 \\
\hline & 4 & 0.367 & 0.415 & 0.367 & 0.348 & 0.342 & 0.383 & 0.383 & 0.347 \\
\hline & 5 & 0.379 & 0.419 & 0.361 & 0.355 & 0.365 & 0.402 & 0.357 & 0.361 \\
\hline & 6 & 0.386 & 0.410 & 0.386 & 0.349 & 0.367 & 0.402 & 0.363 & 0.345 \\
\hline & 7 & 0.364 & 0.410 & 0.353 & 0.345 & 0.369 & 0.390 & 0.370 & 0.349 \\
\hline & 8 & 0.363 & 0.425 & 0.360 & 0.348 & 0.356 & 0.379 & 0.388 & 0.352 \\
\hline & 9 & 0.370 & 0.422 & 0.355 & 0.327 & 0.355 & 0.391 & 0.366 & 0.348 \\
\hline \multirow{9}{*}{4} & 1 & 0.373 & 0.410 & 0.357 & 0.335 & 0.362 & 0.394 & 0.368 & 0.344 \\
\hline & 2 & 0.360 & 0.401 & 0.392 & 0.344 & 0.368 & 0.398 & 30.361 & 0.348 \\
\hline & 3 & 0.378 & 0.403 & 0.379 & 0.333 & 0.379 & 0.404 & 0.345 & 0.328 \\
\hline & 4 & 0.363 & 0.413 & 0.363 & 0.341 & 0.342 & 0.380 & 0.386 & 0.346 \\
\hline & 5 & 0.379 & 0.411 & 0.358 & 0.352 & 0.366 & 0.394 & 0.357 & 0.360 \\
\hline & 6 & 0.375 & 0.412 & 0.376 & 0.345 & 0.369 & 0.394 & 40.363 & 0.348 \\
\hline & 7 & 0.368 & 0.409 & 0.348 & 0.335 & 0.363 & 0.394 & 0.368 & 0.345 \\
\hline & 8 & 0.362 & 0.424 & 0.357 & 0.338 & 0.351 & 0.380 & 0.384 & 0.349 \\
\hline & 9 & 0.372 & 0.416 & 0.347 & 0.326 & 0.351 & 0.386 & 50.360 & 0.340 \\
\hline
\end{tabular}


APÊNDICE 2. (continuação).

\begin{tabular}{|c|c|c|c|c|c|c|c|c|c|}
\hline \multirow[b]{2}{*}{ dia } & \multirow[b]{2}{*}{ tubo } & \multicolumn{4}{|c|}{ prof. $(\mathrm{cm})$ parcela 1} & \multirow{2}{*}{$\frac{\text { prof. }}{20}$} & \multirow{2}{*}{$\frac{(\mathrm{cm}) \mathrm{P}}{50}$} & \multirow{2}{*}{$\begin{array}{c}\text { parcela } \\
100\end{array}$} & \multirow{2}{*}{22} \\
\hline & & 20 & 50 & 100 & 150 & & & & \\
\hline \multirow{9}{*}{5} & 1 & 0.368 & 0.411 & 0.356 & 0.333 & 0.356 & 0.391 & 0.364 & 0.341 \\
\hline & 2 & 0.361 & 0.402 & 0.390 & 0.342 & 0.371 & 0.409 & 0.359 & 0.341 \\
\hline & 3 & 0.379 & 0.409 & 0.377 & 0.330 & 0.384 & 0.403 & 0.343 & 0.329 \\
\hline & 4 & 0.365 & 0.414 & 0.356 & 0.334 & 0.343 & 0.383 & 0.386 & 0.342 \\
\hline & 5 & 0.381 & 0.415 & 0.356 & 0.344 & 0.370 & 0.390 & 0.357 & 0.358 \\
\hline & 6 & 0.376 & 0.416 & 0.373 & 0.341 & 0.371 & 0.397 & 0.356 & 0.341 \\
\hline & 7 & 0.362 & 0.406 & 0.343 & 0.329 & 0.364 & 0.390 & 0.362 & 0.342 \\
\hline & 8 & 0.361 & 0.415 & 0.357 & 0.341 & 0.359 & 0.379 & 0.384 & 0.349 \\
\hline & 9 & 0.372 & 0.421 & 0.346 & 0.320 & 0.350 & 0.387 & 0.356 & 0.338 \\
\hline \multirow{9}{*}{6} & 1 & 0.367 & 0.410 & 0.356 & 0.327 & 0.363 & 0.392 & 0.363 & 0.349 \\
\hline & 2 & 0.365 & 0.397 & 0.387 & 0.338 & 0.374 & 0.403 & 0.359 & 0.343 \\
\hline & 3 & 0.379 & 0.414 & 0.377 & 0.327 & 0.384 & 0.407 & 0.342 & 0.324 \\
\hline & 4 & 0.364 & 0.414 & 0.358 & 0.335 & 0.344 & 0.381 & 0.378 & 0.346 \\
\hline & 5 & 0.385 & 0.413 & 0.356 & 0.350 & 0.368 & 0.394 & 0.356 & 0.353 \\
\hline & 6 & 0.374 & 0.416 & 0.369 & 0.333 & 0.372 & 0.397 & 0.356 & 0.340 \\
\hline & 7 & 0.366 & 0.406 & 0.345 & 0.326 & 0.366 & 0.391 & 0.368 & 0.342 \\
\hline & 8 & 0.365 & 0.416 & 0.357 & 0.340 & 0.354 & 0.378 & 0.381 & 0.340 \\
\hline & 9 & 0.365 & 0.419 & 0.343 & 0.318 & 0.352 & 0.389 & 0.354 & 0.342 \\
\hline \multirow{9}{*}{7} & 1 & 0.369 & 0.406 & 0.354 & 0.327 & 0.361 & 0.389 & 0.365 & 0.342 \\
\hline & 2 & 0.369 & 0.395 & 0.387 & 0.341 & 0.372 & 0.403 & 0.357 & 0.342 \\
\hline & 3 & 0.383 & 0.407 & 0.383 & 0.333 & 0.378 & 0.410 & 0.342 & 0.322 \\
\hline & 4 & 0.369 & 0.410 & 0.355 & 0.334 & 0.341 & 0.381 & 0.377 & 0.342 \\
\hline & 5 & 0.379 & 0.412 & 0.352 & 0.348 & 0.364 & 0.395 & 0.351 & 0.351 \\
\hline & 6 & 0.379 & 0.410 & 0.380 & 0.332 & 0.365 & 0.395 & 0.352 & 0.339 \\
\hline & 7 & 0.371 & 0.412 & 0.349 & 0.331 & 0.367 & 0.389 & 0.363 & 0.342 \\
\hline & 8 & 0.365 & 0.415 & 0.353 & 0.336 & 0.357 & 0.379 & 0.384 & 0.342 \\
\hline & 9 & 0.372 & 0.417 & 0.348 & 0.316 & 0.353 & 0.392 & 0.356 & 0.339 \\
\hline \multirow{9}{*}{8} & 1 & 0.386 & 0.419 & 0.375 & 0.364 & 0.373 & 0.408 & 0.380 & 0.336 \\
\hline & 2 & 0.376 & 0.402 & 0.402 & 0.398 & 0.373 & 0.402 & 0.358 & 0.338 \\
\hline & 3 & 0.377 & 0.403 & 0.379 & 0.328 & 0.378 & 0.396 & 0.341 & 0.318 \\
\hline & 4 & 0.374 & 0.420 & 0.377 & 0.341 & 0.362 & 0.397 & 0.386 & 0.342 \\
\hline & 5 & 0.391 & 0.421 & 0.373 & 0.345 & 0.365 & 0.392 & 0.350 & 0.347 \\
\hline & 6 & 0.382 & 0.420 & 0.376 & 0.338 & 0.371 & 0.398 & 0.358 & 0.341 \\
\hline & 7 & 0.376 & 0.414 & 0.344 & 0.326 & 0.376 & 0.402 & 0.383 & 0.333 \\
\hline & 8 & 0.368 & 0.426 & 0.348 & 0.333 & 0.356 & 0.375 & 0.380 & 0.336 \\
\hline & 9 & 0.379 & 0.426 & 0.352 & 0.320 & 0.364 & 0.398 & 0.359 & 0.333 \\
\hline
\end{tabular}


APÊNDICE 3. Concentraçōes de atrazina (ppb) nas parcelas 1 e 2 por Iinha (L1, L2, L3).

parcela 1

\begin{tabular}{|c|c|c|c|c|c|c|}
\hline \multirow[b]{2}{*}{ Iinha } & \multirow[b]{2}{*}{ prof. } & \multicolumn{5}{|c|}{ coletas } \\
\hline & & 1 & 2 & 3 & 4 & 5 \\
\hline \multirow{6}{*}{ L1 } & & & & $(p p b)$ & & \\
\hline & 20 & 24.612 & 28.426 & 21.939 & 4.619 & 2.579 \\
\hline & 50 & 31.971 & 15.232 & 10.203 & 5.342 & 3.229 \\
\hline & 100 & 1.070 & 47.004 & 15.100 & 10.026 & 11.602 \\
\hline & 150 & 4.865 & 60.415 & 67.353 & 81.768 & 62.598 \\
\hline & 20 & 126.396 & 94.362 & 49.939 & 9.999 & 2.272 \\
\hline \multirow{3}{*}{ L2 } & 50 & 7.845 & 13.430 & 8.983 & 2.760 & 19.763 \\
\hline & 100 & 131.385 & 119.420 & 63.498 & 24.046 & 2.521 \\
\hline & 150 & 0.000 & 2.444 & 162.809 & 71.674 & 154.360 \\
\hline \multirow{4}{*}{ L3 } & 20 & 54.751 & 11.874 & 21.160 & 2.166 & 1.855 \\
\hline & 50 & 17.978 & 12.190 & 5.152 & 2.316 & 6.604 \\
\hline & 100 & 85.194 & 57.739 & 118.204 & 38.513 & 28.051 \\
\hline & 150 & 202.610 & 98.446 & 43.968 & 0.000 & 48.639 \\
\hline
\end{tabular}

parcela 2

\begin{tabular}{|c|c|c|c|c|c|c|}
\hline \multirow[b]{2}{*}{ Iinha } & \multirow[b]{2}{*}{ prof. } & \multicolumn{5}{|c|}{ coletas } \\
\hline & & 1 & 2 & 3 & 4 & 5 \\
\hline \multirow{6}{*}{ L1 } & & & & $(p p b)$ & & \\
\hline & 20 & 36.616 & 33.122 & 6.262 & 3.979 & 2.145 \\
\hline & 50 & 0.000 & 11.607 & 7.058 & 2.690 & 2.005 \\
\hline & 100 & 1.316 & 3.071 & 4.938 & 4.159 & 5.282 \\
\hline & 150 & 0.000 & 6.908 & 3.435 & 3.958 & 5.740 \\
\hline & 20 & 51.455 & 24.274 & 8.531 & 3.722 & 2.488 \\
\hline \multirow[t]{4}{*}{ L 2} & 50 & 2.585 & 11.245 & 3.642 & 0.000 & 4.167 \\
\hline & 100 & 3.415 & 2.597 & 2.483 & 3.278 & 0.000 \\
\hline & 150 & 2.291 & 0.000 & 3.562 & 2.127 & 2.332 \\
\hline & 20 & 42.036 & 21.125 & 6.978 & 1.379 & 3.134 \\
\hline \multirow[t]{3}{*}{ L 3} & 50 & 10.246 & 12.662 & 2.922 & 5.827 & 2.448 \\
\hline & 100 & 0.000 & 2.419 & 8.642 & 6.800 & 3.703 \\
\hline & 150 & 3.890 & 0.000 & 0.000 & 1.871 & 2.491 \\
\hline
\end{tabular}


APÊNDICE 4. Concentraçōes de potássio na solução do solo por coleta e por extrator nas parcelas 1 e 2 .

parcela 1

\begin{tabular}{|c|c|c|c|c|c|c|c|}
\hline \multirow[b]{2}{*}{ extrat. } & \multirow[b]{2}{*}{ prof. } & \multicolumn{5}{|c|}{ coletas } & \multirow[b]{2}{*}{$\mathrm{C5}$} \\
\hline & & test. & $\mathrm{C1}$ & $\mathrm{C} 2$ & C3 & $\mathrm{C4}$ & \\
\hline & & \multicolumn{6}{|c|}{$(\mathrm{ppm})$} \\
\hline 1 & 20 & 8.2 & 8.0 & 8.9 & 8.7 & 9.4 & 9.8 \\
\hline 2 & 50 & 3.1 & 4.2 & 3.4 & 3.1 & - & 3.2 \\
\hline 3 & 100 & 3.8 & 4.3 & 4.1 & 4.0 & - & 4.1 \\
\hline 4 & 150 & 5.9 & 6.1 & 6.0 & 5.9 & $\overline{6} \cdot 0$ & 6.2 \\
\hline 5 & 20 & 9.4 & 10.8 & 12.3 & 12.1 & 12.6 & 13.7 \\
\hline 6 & 50 & 5.7 & 7.0 & 5.9 & 5.8 & 5.7 & 6.1 \\
\hline 7 & 100 & 7.0 & & 8.1 & 7.4 & 7.5 & 7.6 \\
\hline 8 & 150 & & $1 \overline{0.9}$ & 10.8 & 10.5 & 10.6 & 10.8 \\
\hline 9 & 20 & $\overline{9} .1$ & 9.4 & 10.7 & 10.4 & 10.9 & 12.0 \\
\hline 10 & 50 & 4.1 & 4.4 & 4.4 & 4.1 & 4.0 & 4.1 \\
\hline 11 & 100 & 2.3 & 3.0 & 2.6 & 2.4 & & 2.5 \\
\hline 12 & 150 & 3.6 & 6.2 & 3.6 & 3.5 & $\overline{3} .4$ & 3.4 \\
\hline 13 & 20 & 10.9 & 12.1 & 14.3 & & & 15.1 \\
\hline 14 & 50 & 6.8 & 7.1 & 6.7 & $\overline{6} .5$ & $\overline{6} .7$ & 6.9 \\
\hline 15 & 100 & 6.0 & 6.2 & 6.4 & 6.1 & 6.6 & 6.7 \\
\hline 16 & 150 & & 10.3 & 9.8 & 9.7 & 9.8 & 9.8 \\
\hline 17 & 20 & 7.4 & 10.8 & 12.5 & & 12.9 & 13.1 \\
\hline 18 & 50 & 9.9 & 7.6 & 7.7 & $\overline{7} .5$ & 7.9 & 8.2 \\
\hline 19 & 100 & & 10.0 & 9.9 & 9.7 & 9.8 & 10.2 \\
\hline 20 & 150 & - & 14.6 & 10.9 & 10.4 & 10.4 & 10.6 \\
\hline 21 & 20 & $1 \overline{3} .8$ & 12.3 & 14.3 & 14.4 & 15.8 & 16.7 \\
\hline 22 & 50 & 6.0 & 6.1 & 6.2 & 6.0 & 6.1 & 6.6 \\
\hline 23 & 100 & 7.8 & 8.8 & 8.7 & 8.3 & 8.3 & 8.6 \\
\hline 24 & 150 & 6.8 & 7.0 & 7.1 & 6.8 & 6.8 & 6.9 \\
\hline 25 & 20 & 18.9 & 19.2 & 22.8 & 20.7 & 23.1 & 27.0 \\
\hline 26 & 50 & 8.0 & 7.9 & 7.7 & 7.1 & 7.7 & 8.6 \\
\hline 27 & 100 & 8.9 & 9.4 & 10.8 & 9.8 & - & 10.3 \\
\hline 28 & 150 & & 57.6 & 13.8 & & - & 13.4 \\
\hline 29 & 20 & 13.1 & $13 \cdot 3$ & 15.0 & 15.2 & _ & 16.8 \\
\hline 30 & 50 & 6.9 & 10.1 & 7.3 & 7.0 & - & 7.2 \\
\hline 31 & 100 & 4.7 & 21.3 & 7.5 & 7.3 & - & 7.5 \\
\hline 32 & 150 & 5.2 & 5.5 & 5.4 & 5.3 & 5.2 & 5.3 \\
\hline 33 & 20 & 12.2 & 15.4 & 15.3 & 14.7 & - & 16.1 \\
\hline 34 & 50 & 3.7 & 4.0 & 4.1 & 3.8 & 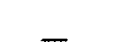 & 4.0 \\
\hline 35 & 100 & 7.6 & 5.3 & 5.0 & 4.5 & $\overline{4} .4$ & 4.7 \\
\hline 36 & 150 & 4.0 & 4.7 & 4.5 & 4.3 & 4.3 & 4.3 \\
\hline
\end{tabular}


APÊNDICE 4. (continuação).

parcela 2

\begin{tabular}{|c|c|c|c|c|c|c|c|}
\hline \multirow[b]{2}{*}{ extrat. } & \multirow[b]{2}{*}{ prof. } & \multicolumn{5}{|c|}{ coletas } & \multirow[b]{2}{*}{$\mathrm{C5}$} \\
\hline & & test. & CI & $\mathrm{C2}$ & C3 & $\mathrm{C4}$ & \\
\hline & & \multicolumn{6}{|c|}{ (ppm) } \\
\hline 1 & 20 & 7.6 & 9.7 & 14.3 & $1 \overline{2.6}$ & 14.1 & 15.1 \\
\hline 2 & 50 & 8.8 & 8.4 & 8.5 & & & 8.7 \\
\hline 3 & 100 & - & - & 7.5 & $\overline{7} \cdot 3$ & $\overline{7} .2$ & 7.5 \\
\hline 4 & 150 & - & - & 9.8 & 7.4 & 6.8 & 6.5 \\
\hline 5 & 20 & $1 \overline{2} \cdot 3$ & $1 \overline{5} .4$ & 17.5 & 17.8 & 18.2 & 18.6 \\
\hline 6 & 50 & 4.3 & 4.9 & 4.6 & 4.3 & 4.6 & 4.7 \\
\hline 7 & 100 & 3.1 & 3.9 & 3.1 & 3.2 & 3.1 & 3.1 \\
\hline 8 & 150 & 1.7 & 1.8 & 1.8 & 1.4 & 1.5 & 1.5 \\
\hline 9 & 20 & 12.6 & 13.5 & 14.9 & 14.9 & 15.5 & 16.1 \\
\hline 10 & 50 & 5.3 & 5.4 & 5.6 & 5.5 & 5.7 & 5.8 \\
\hline 11 & 100 & 4.7 & 4.8 & 5.6 & $4 \cdot 5$ & - & 4.7 \\
\hline 12 & 150 & 7.2 & 33.9 & 11.7 & 10.0 & - & \\
\hline 13 & 20 & 11.7 & 12.5 & 14.1 & 14.1 & $1 \overline{5} .9$ & $1 \overline{5} .9$ \\
\hline 14 & 50 & 6.8 & 8.0 & 7.2 & & 7.4 & 7.7 \\
\hline 15 & 100 & 4.4 & 10.6 & 4.6 & $\overline{4} \cdot 2$ & 4.3 & 4.5 \\
\hline 16 & 150 & 4.0 & 4.2 & 4.2 & $4 \cdot 1$ & $4 \cdot 1$ & 4.2 \\
\hline 17 & 20 & 19.4 & 30.0 & 27.6 & 27.9 & 29.1 & 31.2 \\
\hline 18 & 50 & 13.1 & 13.5 & 13.0 & 12.9 & 13.2 & 13.9 \\
\hline 19 & 100 & 8.0 & 8.9 & 8.4 & 8.4 & 8.1 & 8.5 \\
\hline 20 & 150 & 8.8 & 9.3 & 9.0 & 9.0 & 8.8 & 9.1 \\
\hline 21 & 20 & 10.6 & 14.8 & 17.7 & 18.7 & 20.7 & 22.5 \\
\hline 22 & 50 & 10.4 & 9.9 & 10.0 & 9.6 & 10.1 & 10.6 \\
\hline 23 & 100 & 8.3 & 8.8 & 8.5 & 8.0 & 10.3 & 12.0 \\
\hline 24 & 150 & 13.3 & 13.8 & 14.0 & 13.8 & 13.7 & 14.2 \\
\hline 25 & 20 & 24.0 & 20.1 & 24.3 & 25.8 & 26.4 & 30.9 \\
\hline 26 & 50 & 17.2 & 17.5 & 18.2 & 17.5 & & 19.3 \\
\hline 27 & 100 & 7.0 & 9.0 & 7.3 & $7 \cdot 3$ & $\overline{7} .2$ & 7.4 \\
\hline 28 & 150 & 3.0 & 3.4 & & 7.1 & 3.6 & 3.5 \\
\hline 29 & 20 & 17.4 & 21.0 & $2 \overline{3} \cdot 1$ & 23.4 & 26.1 & 27.9 \\
\hline 30 & 50 & 11.8 & 12.5 & 12.0 & 11.4 & 11.9 & 12.5 \\
\hline 31 & 100 & 5.4 & 20.7 & 5.1 & 4.6 & 4.4 & 5.1 \\
\hline 32 & 150 & 5.3 & 6.0 & 5.4 & $5 \cdot 3$ & 5.4 & 5.5 \\
\hline 33 & 20 & & 19.4 & 19.4 & 18.9 & & 25.2 \\
\hline 34 & 50 & $1 \overline{3} .8$ & 18.2 & 14.8 & 13.1 & $1 \overline{3} \cdot 6$ & 14.7 \\
\hline 35 & 100 & 9.1 & 11.1 & 10.1 & 9.2 & 9.1 & 9.5 \\
\hline 36 & 150 & - & 15.8 & 14.2 & - & - & - \\
\hline
\end{tabular}


93 .

APÊNDICE 5. Concentrações de cloreto na solução do solo por coleta e por extrator nas parcelas 1 e 2 .

parcela 1

\begin{tabular}{|c|c|c|c|c|c|c|c|}
\hline \multirow[b]{2}{*}{ extrator } & \multicolumn{7}{|c|}{ coletas } \\
\hline & prof. & test. & C1 & $\mathrm{C} 2$ & C3 & $\mathrm{C4}$ & $\mathrm{C5}$ \\
\hline & & & & & (ppm) & & \\
\hline 1 & 20 & 2.4 & 7.8 & 14.9 & 14.1 & 19.5 & 20.8 \\
\hline 2 & 50 & 1.9 & 3.2 & 1.6 & 1.3 & & 2.1 \\
\hline 3 & 100 & 1.4 & 1.4 & 1.0 & 1.1 & - & 2.1 \\
\hline 4 & 150 & 1.4 & 1.3 & 1.1 & 1.1 & $\overline{2} .6$ & 3.2 \\
\hline 5 & 20 & 1.8 & 20.2 & 33.7 & 31.3 & 38.5 & 45.1 \\
\hline 6 & 50 & 2.2 & 3.4 & 2.1 & 3.6 & 5.8 & 7.4 \\
\hline 7 & 100 & 2.6 & 10.5 & 2.4 & 2.1 & 2.2 & 2.0 \\
\hline 8 & 150 & & 2.5 & 1.7 & 1.4 & 1.8 & 1.8 \\
\hline 9 & 20 & $\overline{2} .0$ & 11.8 & 17.4 & 18.3 & 25.3 & 31.8 \\
\hline 10 & 50 & 1.9 & 2.2 & 3.8 & 4.8 & 8.5 & 9.3 \\
\hline 11 & 100 & 2.8 & 3.0 & 1.7 & 1.9 & 2.2 & 1.8 \\
\hline 12 & 150 & 2.6 & 5.0 & 1.6 & 1.9 & 1.9 & 1.4 \\
\hline 13 & 20 & 2.1 & 18.5 & 42.7 & & & 48.0 \\
\hline 14 & 50 & 2.4 & 2.3 & 1.9 & $\overline{2} .5$ & $\overline{4} .5$ & 6.0 \\
\hline 15 & 100 & 1.7 & 1.7 & 1.2 & 1.4 & 1.8 & 1.8 \\
\hline 16 & 150 & & 3.4 & 1.8 & 2.2 & 2.2 & 1.5 \\
\hline 17 & 20 & $\overline{1} .7$ & 30.8 & 52.9 & 30.1 & 60.9 & 60.2 \\
\hline 18 & 50 & 2.4 & 2.1 & 3.4 & 4.8 & 9.7 & 11.6 \\
\hline 19 & 100 & - & 2.7 & 1.9 & 2.4 & 3.6 & 4.7 \\
\hline 20 & 150 & - & 7.9 & 2.9 & 3.2 & 2.5 & 2.3 \\
\hline 21 & 20 & $\overline{1} \cdot 9$ & 18.6 & 36.8 & 44.1 & 47.1 & 51.7 \\
\hline 22 & 50 & 1.8 & 2.1 & 1.8 & 3.2 & 4.3 & 5.6 \\
\hline 23 & 100 & 2.5 & 2.7 & 1.9 & 2.2 & 2.6 & 4.5 \\
\hline 24 & 150 & 1.2 & 1.2 & 1.3 & 1.3 & 1.1 & 1.1 \\
\hline 25 & 20 & 2.4 & 19.3 & 39.4 & 45.5 & 48.2 & 71.4 \\
\hline 26 & 50 & 2.7 & 3.1 & 3.2 & 3.8 & 6.0 & 6.9 \\
\hline 27 & 100 & 2.4 & 2.5 & 17.9 & 13.7 & - & 8.1 \\
\hline 28 & 150 & & 42.3 & 2.1 & & 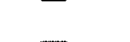 & 1.8 \\
\hline 29 & 20 & $\overline{1} .5$ & 5.8 & 17.4 & $2 \overline{4} \cdot 6$ & - & 28.9 \\
\hline 30 & 50 & 2.0 & 5.0 & 1.9 & 2.4 & 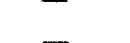 & 2.0 \\
\hline 31 & 100 & 1.9 & 9.5 & 2.5 & 1.8 & - & 2.0 \\
\hline 32 & 150 & 1.3 & $1 \cdot 4$ & 1.3 & 1.1 & $\overline{1} .5$ & 1.2 \\
\hline 33 & 20 & 3.0 & 17.5 & 26.2 & 29.0 & - & 28.0 \\
\hline 34 & 50 & 2.8 & 1.7 & 2.1 & 1.8 & - & 2.5 \\
\hline 35 & 100 & 2.1 & 2.8 & 2.4 & 1.4 & $\overline{1} .9$ & 3.3 \\
\hline 36 & 150 & 1.9 & 2.3 & 1.7 & 1.4 & 1.8 & 1.6 \\
\hline
\end{tabular}


APÊNDICE 5. (Continuação) .

Parcela 2

\begin{tabular}{|c|c|c|c|c|c|c|c|}
\hline \multirow[b]{2}{*}{ extrator } & \multicolumn{7}{|c|}{ coletas } \\
\hline & prof. & test. & C1 & $\mathrm{C} 2$ & C3 & C4 & $\mathrm{C5}$ \\
\hline & & & & & & & \\
\hline 1 & 20 & 2.0 & 11.1 & 66.0 & 57.6 & 57.6 & 62.6 \\
\hline 2 & 50 & 3.9 & 4.0 & 3.8 & & & 4.0 \\
\hline 3 & 100 & & & 3.6 & $\overline{3} .8$ & $\overline{3} .3$ & 2.9 \\
\hline 4 & 150 & - & - & 12.6 & 7.1 & 4.7 & 4.0 \\
\hline 5 & 20 & $\overline{3} .3$ & $3 \overline{2} .9$ & 80.7 & 80.7 & 78.8 & 67.6 \\
\hline 6 & 50 & 3.7 & 5.9 & 5.3 & 4.6 & 8.5 & 12.5 \\
\hline 7 & 100 & 3.5 & 4.1 & 3.1 & 3.0 & 3.1 & 2.6 \\
\hline 8 & 150 & & 3.4 & 3.3 & 2.9 & 3.1 & 2.5 \\
\hline 9 & 20 & $\overline{2} .9$ & 27.7 & 55.3 & 60.9 & 62.6 & 65.1 \\
\hline 10 & 50 & 2.8 & 3.3 & 2.4 & 3.8 & 4.1 & 5.0 \\
\hline 11 & 100 & 3.2 & 3.6 & 2.7 & 2.9 & 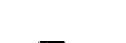 & 2.6 \\
\hline 12 & 150 & 3.6 & 41.0 & 7.9 & 6.0 & & \\
\hline 13 & 20 & 2.1 & 3.3 & 42.7 & 45.5 & $4 \overline{6} .7$ & $5 \overline{2} \cdot 9$ \\
\hline 14 & 50 & 2.4 & 2.5 & 3.6 & & 8.8 & 9.3 \\
\hline 15 & 100 & 3.3 & 7.3 & 2.1 & $\overline{2} \cdot 9$ & 2.2 & 2.2 \\
\hline 16 & 150 & 2.8 & 2.9 & 2.1 & 2.5 & 2.5 & 2.3 \\
\hline 17 & 20 & 2.5 & 38.6 & 61.7 & 75.0 & 75.0 & 87.8 \\
\hline 18 & 50 & 2.1 & 1.9 & 2.9 & 4.8 & 9.4 & 12.5 \\
\hline 19 & 100 & 2.7 & 2.7 & 1.8 & 2.1 & 2.1 & 2.1 \\
\hline 20 & 150 & 2.8 & 3.1 & 1.9 & 2.4 & 2.5 & 2.1 \\
\hline 21 & 20 & 1.9 & 9.9 & 41.4 & 62.6 & 76.9 & 92.2 \\
\hline 22 & 50 & 2.5 & 2.5 & 2.5 & 2.1 & 6.5 & 10.4 \\
\hline 23 & 100 & 2.3 & 2.6 & 2.1 & 1.7 & 39.7 & 46.8 \\
\hline 24 & 150 & 4.2 & 3.8 & 3.0 & 2.7 & 4.0 & 3.5 \\
\hline 25 & 20 & 1.8 & 2.1 & 11.8 & 14.9 & 28.2 & 36.8 \\
\hline 26 & 50 & 1.9 & 1.5 & 1.7 & 3.4 & & 7.4 \\
\hline 27 & 100 & 2.4 & 3.4 & 1.6 & 1.7 & $\overline{2} .6$ & 2.7 \\
\hline 28 & 150 & 3.2 & 2.7 & & 6.8 & 2.6 & 2.2 \\
\hline 29 & 20 & 2.3 & 4.4 & $1 \overline{9} .2$ & 27.8 & 39.7 & 44.5 \\
\hline 30 & 50 & 1.4 & 2.2 & 1.8 & 3.4 & 6.7 & 10.4 \\
\hline 31 & 100 & 2.8 & 14.6 & 1.9 & 1.9 & 2.1 & 2.2 \\
\hline 32 & 150 & 2.7 & 2.1 & 1.8 & 2.1 & 2.2 & 2.2 \\
\hline 33 & 20 & & 1.9 & 7.9 & 12.2 & & 50.5 \\
\hline 34 & 50 & $\overline{1} .9$ & 2.6 & 1.7 & 1.7 & $\overline{6} .7$ & 8.6 \\
\hline 35 & 100 & 2.1 & 1.9 & 1.6 & 1.7 & 2.1 & 2.3 \\
\hline 36 & 150 & - & 4.1 & 1.9 & - & - & - \\
\hline
\end{tabular}

